\title{
Analysis of the Professionalisation of the Senior Civil Service and the Way Forward for the Western Balkans
}

SIGMA PAPER No. 55

Authorised for publication by Karen Hill, Head of the SIGMA Programme 


\section{Table of contents}

List of abbreviations and acronyms.................................................................................................................. 5

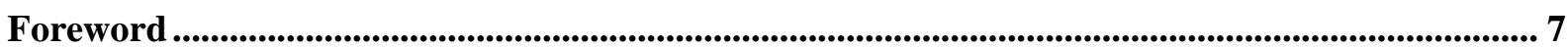

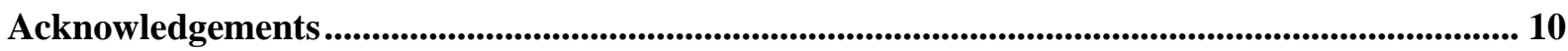

Executive summary ......................................................................................................................................... 11

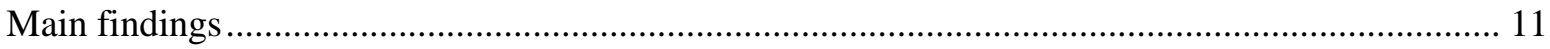

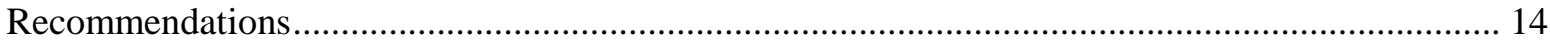

1. What is a professional senior civil service and how can it be established? ................................. 15

1.1. Senior civil service composition and employment conditions ....................................... 19

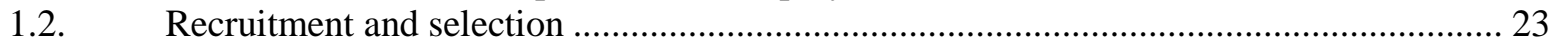

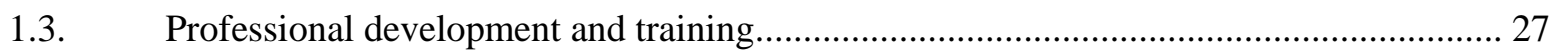

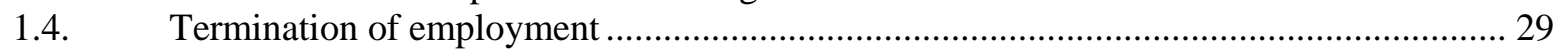

1.5. Senior civil service policy co-ordination and management........................................... 31

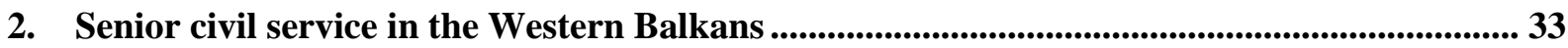

2.1. Senior civil service composition and employment conditions ......................................... 34

2.1.1. What constitutes the senior civil service in the Western Balkans?............................... 34

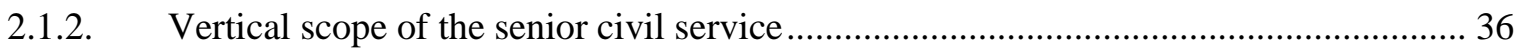

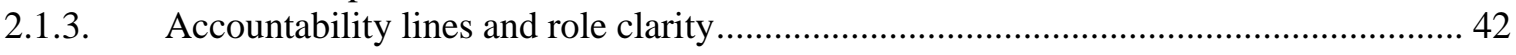

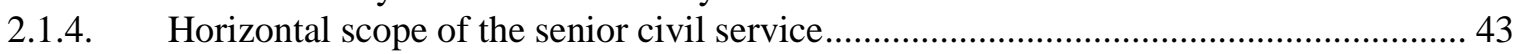

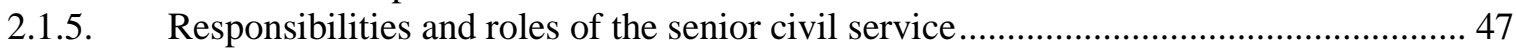

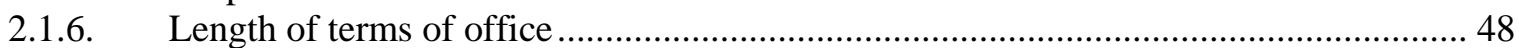

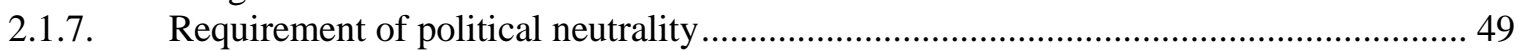

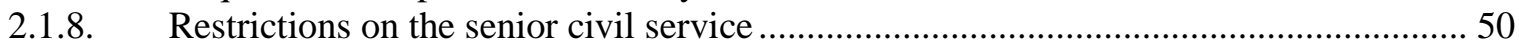

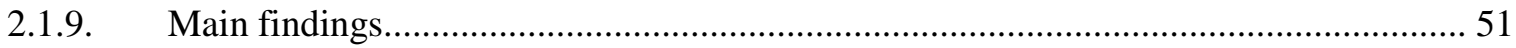

2.2. Recruitment and selection for senior civil service positions ......................................... 52

2.2.1. Comparative overview of the recruitment process across the Western Balkans ............ 53

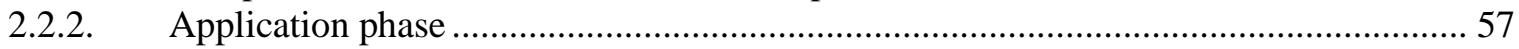

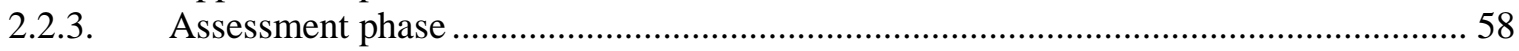

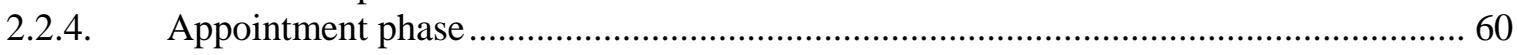

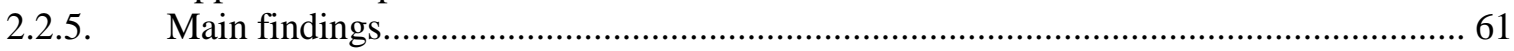

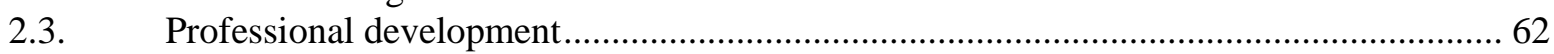

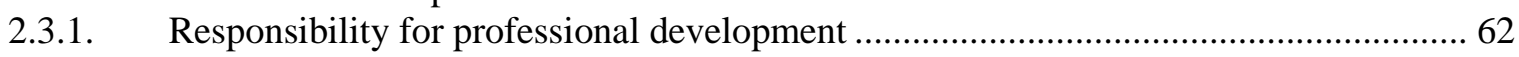

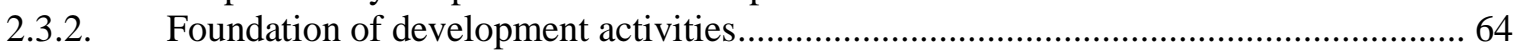

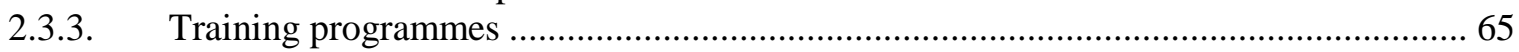

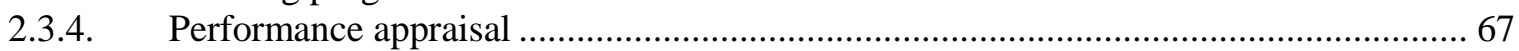

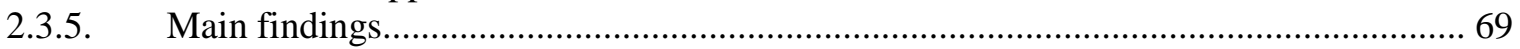

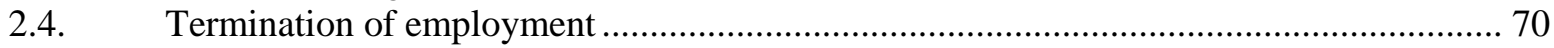

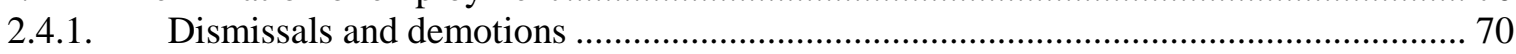

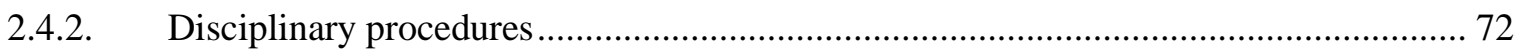




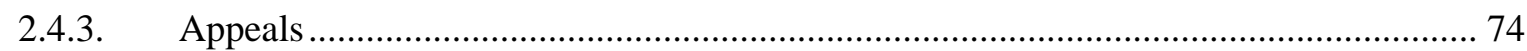

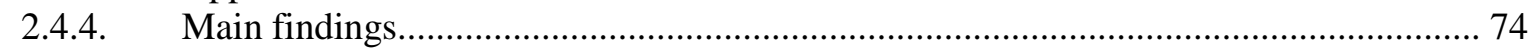

2.5. Policy co-ordination and management of the senior civil service ................................... 74

2.5.1. Responsibility for senior civil service policy co-ordination and management............... 74

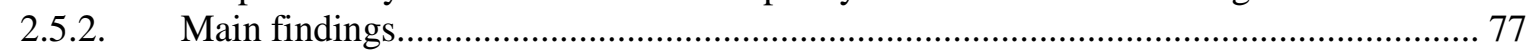

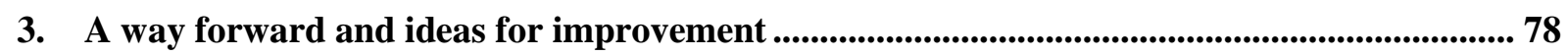

Annex 1. Framework for professionalisation of the senior civil service ........................................... 82

Annex 2. Management hierarchy of ministries in the Western Balkans ....................................... 84

Annex 3. Description of recruitment processes in the Western Balkans............................................. 90

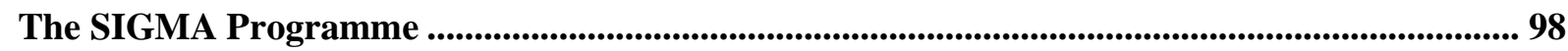




\section{Tables}

Table 1. Senior managerial positions as defined in legislation in the Western Balkans 38

Table 2. Vertical scope of the senior civil service in the Western Balkans, in ministries and in bodies subordinated to ministries by SIGMA definition

Table 3. Administrative management models of ministries in the Western Balkans ............................ 43

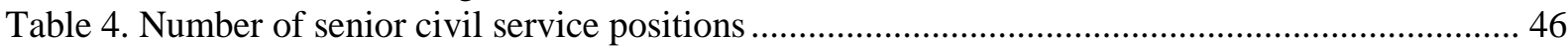

Table 5. Delegation of decision making from minister or secretary to a lower level in administrations across the Western Balkans (number of instances in 34 ministries questioned) ........................... 47

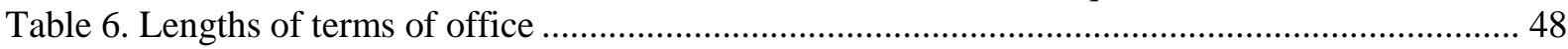

Table 7. Comparison of senior civil service recruitment processes in the Western Balkans ................ 53

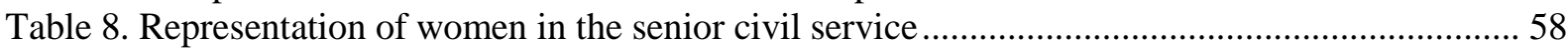

Table 9. Progress in elaborating senior civil service competency frameworks in the Western Balkans59

Table 10. Responsibility for providing professional development for the senior civil service ............. 63

Table 11. Training programmes designed for senior civil servants in Western Balkan administrations66

Table 12. Overview of senior civil service performance appraisals in the Western Balkans................ 68

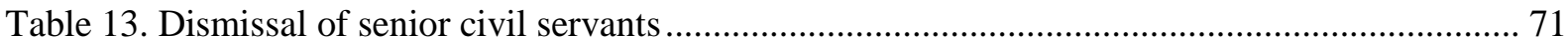

Table 14. Protection of senior civil servant rights in disciplinary procedures ...................................... 73

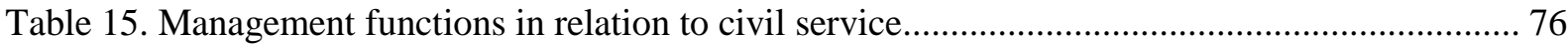

\section{Figures}

Figure 1. The value of a merit-based senior civil service................................................................... 18

Figure 2. Key components and expected results of appropriate senior civil service composition and

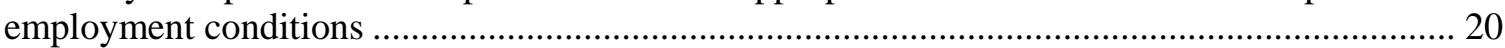

Figure 3. Key components and expected results of merit-based recruitment and selection of senior

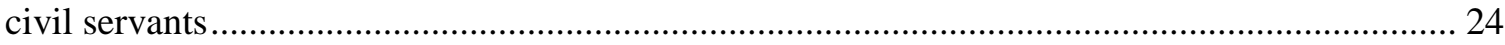

Figure 4. Key components and expected results of senior civil service professional development...... 28

Figure 5. Key components and expected results of termination of office in the senior civil service .... 30

Figure 6. Key components and expected results of senior civil service policy co-ordination and

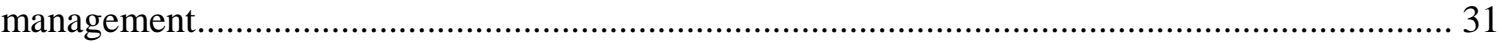

Figure 7. Two ministry governance models in the Western Balkans ................................................... 42

Figure 8. Horizontal application of the senior civil service concept ................................................... 45

\section{Boxes}

Box 1. The difference between political and senior civil service positions, and possible anomalies ... 36 


\section{List of abbreviations and acronyms}

$\begin{array}{ll}\text { ASPA } & \text { Albanian School of Public Administration } \\ \text { BiH } & \text { Bosnia and Herzegovina } \\ \text { CSA } & \text { Civil Service Agencies (BiH) } \\ \text { CSL } & \text { Civil Service Law } \\ \text { CCSM } & \text { Commissioner for Civil Service Monitoring (Albania) } \\ \text { CSMP } & \text { Council on Senior Management Positions (Kosovo*) } \\ \text { DoPA } & \text { Department of Public Administration (Albania) } \\ \text { EU } & \text { European Union } \\ \text { FBiH } & \text { Federation of Bosnia and Herzegovina } \\ \text { HRM } & \text { human resource management } \\ \text { HRMA } & \text { Human Resource Management Authority (Montenegro) } \\ \text { HRMS } & \text { Human Resource Management Service (Serbia) } \\ \text { IT } & \text { information technology } \\ \text { IOB } & \text { Independent Oversight Board (Kosovo) } \\ \text { KIPA } & \text { Kosovo Institute of Public Administration } \\ \text { LSE } & \text { London School of Economics } \\ \text { MPA } & \text { Ministry of Public Administration } \\ \text { MISA } & \text { Ministry of Information Society and Administration (the former } \\ \text { MoF } & \text { Yugoslav Republic of Macedonia) } \\ \text { MPALSG } & \text { Ministry of Finance } \\ \text { NGO } & \text { Ministry of Public Administration and Local Self-Government } \\ \text { NSC } & \text { Non-governmental organisation } \\ \text { OECD } & \text { National Selection Committee (Albania) } \\ & \text { Organisation for Economic Co-operation and Development } \\ & \end{array}$

* This designation is without prejudice to positions on status, and is in line with United Nations Security Council Resolution 1244/99 and the Advisory Opinion of the International Court of Justice on Kosovo's declaration of independence. 
OPM Office of the Prime Minister (Albania)

PAR public administration reform

SIGMA Support for Improvement in Governance and Management

SIOFA Secretariat for Implementation of the Ohrid Framework Agreement (the former Yugoslav Republic of Macedonia)

ReSPA Regional School of Public Administration

RS Republika Srpska

SCS senior civil service

TMC Top Management Corps (Albania)

UK United Kingdom 


\section{Foreword}

The civil service shapes the face of any government. It is the professional body of government employees that have a special role in serving the public interest by advising on the development of policies and putting them into practice. Within this group, there is an even smaller core that forms the link between the civil service and the democratically elected cabinet of ministers: this is the senior civil service (SCS). Its role is special: not only does it execute government policies and advise ministers on how to convert the government's political programme into concrete actions, it must also safeguard the core mission of the state, which is independent of the government in office. The professionalism of senior civil servants in managing government affairs is therefore crucial to a government's success or failure.

Ministers are politically mandated to devise policies and run the ministry, while senior civil servants simultaneously serve the government in office and the public interest in general. A clear definition of responsibilities is needed to provide optimal conditions for all to perform their respective functions. This means there are responsibilities that only politically mandated officials can assume, such as making value judgements about policy needs, and others that can be best fulfilled by professional civil servants, for instance deciding the most effective way to provide a service or make the government function more efficiently.

This paper examines civil service professionalisation in Albania, Bosnia and Herzegovina (BiH), the former Yugoslav Republic of Macedonia, Kosovo, Montenegro and Serbia. For $\mathrm{BiH}$, the senior civil service is analysed separately for the state level (henceforth the BiH State level), the Federation of Bosnia and Herzegovina $(\mathrm{FBiH})$, and the Republika Srpska (RS). The District of Brčko is not considered in this report, neither are the cantons within the $\mathrm{FBiH}$. There are therefore eight systems analysed in all, referred to in this paper as administrations. This paper draws on earlier work in this area: SIGMA Paper No. 48, Civil Service Professionalisation in the Western Balkans ${ }^{1}$; the Organisation for Economic Co-operation and Development (OECD) publications Senior Civil Service: Building the Skills and Leadership for Public Sector Performance ${ }^{2}$, Study on the Political Involvement in Senior Staffing Decisions and on the Delineation of Responsibilities Between Ministers and Senior Civil Servants ${ }^{3}$ and Skills for a High Performing Civil Service ${ }^{4}$; and the Regional

\footnotetext{
${ }^{1}$ Meyer-Sahling, J. (2012), Civil Service Professionalisation in the Western Balkans, SIGMA Paper No. 48, OECD Publishing, Paris. http://dx.doi.org/10.1787/5k4c42jrmp35-en

2 OECD (2016), Senior Civil Service: Building the Skills and Leadership for Public Sector Performance, OECD Publishing, Paris.

${ }^{3}$ Matheson, A. et al. (2007), Study on the Political Involvement in Senior Staffing and on the Delineation of Responsibilities Between Ministers and Senior Civil Servants, OECD Working
} 
School of Public Administration (ReSPA) study The Professionalisation of the Civil Service between Politics and Administration ${ }^{5}$ and the working paper Improving the implementation of merit recruitment procedure in the Western Balkans: analysis and recommendations ${ }^{6}$.

This report analyses and compares the practices of these Western Balkan administrations - and distinguishes good practices from those that hinder the development of a more professional SCS - to demonstrate to decision makers that a merit-based SCS is useful. It is intended to help senior-ranking decision makers, both at the political and SCS level, design institutions with the potential to support greater professionalism, and suggests ways forward based on available good practices from both the EU and OECD member countries as well as the Western Balkans.

This study is grounded in an analytical framework that models conditions needed to establish a professional SCS. This framework, presented in Chapter 1, is based on the SIGMA Principles of Public Administration ${ }^{7}$, particularly Principle 4 under Public Service and Human Resource Management, which prescribes that "direct or indirect political influence on senior managerial positions in the public service is prevented", and supported by OECD analytical work on the SCS ${ }^{8}$. Chapter 2 analyses Western Balkan institutional frameworks and practices, covering the composition of the SCS and its employment conditions, recruitment and selection, professional development, termination of employment, and SCS policy co-ordination and management. Analysis is based on information gathered in the SIGMA 2017 Monitoring Reports ${ }^{9}$ in the region, and on data collected specifically for this study with the help of local experts and bodies responsible for the civil service. To understand practices, qualitative interviews were conducted with current and former civil servants in all administrations, as well as with politicians and non-governmental stakeholders. To test

Papers on Public Governance, No. 6, OECD Publishing, Paris.
http://dx.doi.org/10.1787/136274825752.

4 OECD (2017a), Skills for a High Performing Civil Service, OECD Publishing, Paris. http://dx.doi.org/10.1787/9789264280724-en.

5 Meyer-Sahling, J.-H. (Ed.) (2016) Professionalisation of the Civil Service between Politics and Administration, $8^{\text {th }}$ ReSPA Annual Conference Proceedings. Danilovgrad: ReSPA Publications.

6 Meyer-Sahling, J.-H. et al. (2015), Improving the Implementation of Merit Recruitment Procedures in the Western Balkans: Analysis and Recommendations, ReSPA Publications, Danilovgrad, Montenegro.

7 OECD (2017b), SIGMA, The Principles of Public Administration, OECD, Paris, http://www.sigmaweb.org/publications/Principles-of-Public-Administration_Edition2017 ENG.pdf

${ }^{8}$ OECD (2017c), Government at a Glance 2017, OECD Publishing, Paris.

http://dx.doi.org/10.1787/gov_glance-2017-en, aligned with methodology presented in Annex E, p. 5. http://www.oecd.org/gov/Annex\%20E\%20and\%20country\%20notes\%20Final\%20july\%2016 $\% 20$ FINAL $\% 20 \% 282 \% 29$.pdf

${ }^{9}$ OECD (2017d) SIGMA, Monitoring Reports, OECD, Paris

http://www.sigmaweb.org/publications/monitoring-reports.htm 
initial ideas and verify information, the bodies responsible for civil service management were consulted in each of the administrations. Chapter 3 concludes this study with directions for progress and ideas for improvements. SIGMA is developing a separate report on managerial accountability in the Western Balkans, so this topic is not addressed here. 


\section{Acknowledgements}

This paper was developed by the SIGMA team consisting of Annika Uudelepp (team leader), Juhani Lemmik, Kaido Paabusk and Wojciech Zielinski, and they received contributions from SIGMA experts Klas Klaas, Lech Marcinkowski, Primoz Vehar and Xavier Sisternas. Substantial expert contributions were also received from JanHinrik Meyer-Sahling of the University of Nottingham, and the team extends its gratitude to Salvador Parrado for his early contribution to the preparation of this paper as well as to Damir Ahmetovic, Milena Lazarevic, Vladimir Mihajlovic, Milena Milosevic, Hamit Qeriqi, Viktorija Sazdova, Ansi Shundi and Jasmina Trajkovski for their invaluable contributions to data collection and for sharing their first-hand insights into country practices. Finally, the team would like to thank all the Western Balkan representatives who provided very useful feedback during various phases of this paper's development. 


\section{Executive summary}

Civil service professionalisation is one of the main challenges for the Western Balkans ${ }^{10}$. Professionalisation of the senior civil service (SCS) is a key determinant of organisational performance in the public sector, which, in turn, helps the government in office fulfil its policy objectives. The SCS is defined as "professional civil servants employed in top-level management positions in the national civil service, formally or informally recognised as a separate group. They are competitively appointed to functions that cover policy advice, operational delivery or corporate service delivery" ". Current Western Balkan practices are still rather far from meeting this definition, as several key characteristics are weak or even absent.

In examining a professional SCS, the paper focuses on two core features: professional competency and political responsiveness. At the core of attaining competency is the application of the principle of merit. This means making appointments based on qualifications and competence, eliminating discrimination in all aspects of employment, and promoting values and attitudes that result in law-abiding, transparent, ethical and performance-orientated behaviour. Political responsiveness is also needed in the SCS to build a functional and trusting relationship between ministers and senior administrative managers: it means the SCS is committed to professionally implementing the sitting government's policy, which expresses the preferences of the electorate.

\section{Main findings}

This study looked at five critical areas for further professionalisation of the SCS in the Western Balkans.

1) Delineation of senior civil servants as a special group in terms of composition, responsibilities, accountability lines and employment conditions. Separate identification not only reinforces the boundaries between neutral, professional seniorlevel officials and political positions, but also safeguards the accountability, institutional continuity and sustainability of public policy programmes. Clarity in lines

\footnotetext{
${ }^{10}$ Meyer-Sahling, J.-H. et al. (2015).

11 This definition builds on previous definitions of the SCS used in the SIGMA 2017 Monitoring Reports; OECD (2017e), SIGMA, Methodological Framework for the Principles of Public Administration, OECD, Paris, 96, http://www.sigmaweb.org/publications/Methodological-Framework-for-the-Principles-ofPublic-Administration-November-2017.pdf; and OECD (1995), Top Management Service in Central Government: Introducing a System for the Higher Civil Service in Central and Eastern European Countries, SIGMA Paper No. 1, OECD Publishing, Paris.
} 
of accountability is a precondition for proper oversight and control of the work of senior civil servants.

The boundaries of the SCS have been defined in most administrations, but managerial accountability lines are often blurred. In terms of scope, this group varies significantly from rather restricted (Kosovo) to broad and deep (Serbia, the Bosnia and Herzegovina State level and the Republika Srpska). However, there is a lack of consistency in applying the rules to similar types of government bodies. In some administrations, despite the fact that heads of executive government bodies are considered civil service positions, the principle of merit is often not applied to recruiting and dismissing these officials, making them subject to undue political intervention.

Only Albania, Kosovo and the former Yugoslav Republic of Macedonia have clear administrative management models for ministries, with distinct lines of accountability. In other administrations there are multiple accountability lines between political and SCS positions, blurring the boundary between them and obscuring their roles. This makes the effective management of ministries and their subordinate agencies difficult.

In most of the Western Balkan administrations surveyed, a fixed service term (three to five years) is applied to SCS positions. Only in the former Yugoslav Republic of Macedonia does the service term coincide with the electoral cycle and result in the institutionalised turnover of ministry secretaries. Although the legal framework in most of the administrations clearly stipulates political neutrality, it is difficult to conclude that it is being followed in practice.

2) Recruitment and selection of senior civil servants. The ultimate purpose of a well-functioning recruitment and selection system is to screen and identify candidates who have the professional competence to effectively perform senior civil servant tasks. Such a system (whether internal competition or open to external candidates) consists of three distinct phases (application, testing and selection, and final appointment), ensuring merit-based recruitment process for SCS positions.

Current recruitment systems and practices do not sufficiently ensure professional competence for SCS positions. First, the small number of eligible applicants per position significantly limits the competitiveness of recruitment. Second, testing systems are not robust and rigorous enough to screen for competence levels and fulfil the needs of open competition, as they mostly assess knowledge and formal requirements rather than the competencies needed for senior positions. Third, there are no comprehensive competency models in place defining expectations for senior civil servants and providing a relevant basis for testing candidates. Fourth, members of selection committees are often not equipped with professional selection skills, and their neutrality is not always ensured. The central bodies that direct recruitment processes have very limited capacities and rather technical roles (except in Albania). Fifth, final selection rules often allow for wide political discretion, specifically for SCS positions, which ministers tend to use in practice, and which undermines the appointment of competent managers. Overall, this diminishes confidence in selection procedures.

3) Training and development. A solid foundation of professional development and training is required to both address the individual development needs of senior civil servants and communicate the collective ethos and working culture of the SCS. 
Performance appraisals should also be used to support the professional development and performance of managers.

Professional development is not well established in most of the Western Balkan administrations, except in Albania, where much emphasis has been placed on creating a professional development system specific to the SCS. Serbia and the Federation of Bosnia and Herzegovina $(\mathrm{FBiH})$ have also recently launched professional development programmes targeted specifically at senior civil servants. Although most administrations have special institutions for public service management that undertake training and development, they do not provide systematic and regular programmes specially designed for the SCS, except in Albania. Professional development is not systematically grounded, as competency models are still missing in most administrations and no other tools are being used to comprehensively analyse training needs at the senior level. Performance appraisal systems are formally in place, but they are not linked to professional development activities, and in some cases they are not carried out in practice or are conducted as a formality only.

4) Termination of employment. Fair and objective criteria for dismissals and demotions, along with transparent and well-recorded procedures, contribute to a professional SCS in two ways. First, they provide job protection and stability; second, the grounds established for termination can also be used as a basis for measuring improvement in SCS performance standards.

Legislation in the Western Balkan administrations mostly provides a solid legal basis for dismissing senior civil servants. However, in some administrations dismissal is possible after only one negative performance appraisal. Also, the misuse of acting positions, such as the extensive appointment of acting senior civil servants in Serbia, jeopardises the stability of the SCS (by weakening job security) and its capacity for impartial action. Legislation in most administrations contains sound provisions for SCS disciplinary procedures, and the right to appeal dismissal decisions and disciplinary rulings is ensured.

5) Policy co-ordination and management of the SCS. A specific government policy is required to set clear objectives and a strategy for professionalising the SCS. An integrated approach that treats senior civil servants as a common pool of talent is also needed. This is based on the principle that senior civil servants need to be invested in and developed together so that they share common values and obtain the skill sets needed to manage public organisations, wherever they are placed.

Central bodies that deal with SCS management do not devote sufficient attention to it. Because SCS issues are dealt with by civil service offices, not enough deliberate attention is paid to managing senior civil servants as a common pool; central civil service offices tend to offer more technical assistance than strategic support for the SCS. Although initial steps have been taken by some of these bodies (in Serbia and Montenegro) to devise frameworks for a more integrated approach to SCS management, there is a general lack of SCS-specific government policy. Public administration reform strategies do not usually address the needs of this group specifically, and objectives that do touch upon senior civil servants deal with specific aspects only. 


\section{Recommendations}

To develop their SCS, the Western Balkan administrations could take the following steps:

1. Reach a wide political consensus on building a professional SCS and on respecting the principle of merit in the SCS. Such consensus will have to include parties currently in opposition.

2. Clearly describe the responsibilities of all political and SCS positions in the hierarchy of executive organisations.

3. Clearly define the composition of the SCS, both vertically and horizontally.

4. Agree on measures to effectively limit political interference in the SCS - from recruitment to daily operations and job security - to ensure that the professional competence of senior civil servants is not compromised.

5. Attract qualified applicants to SCS vacancies to increase competitiveness and the level of competition.

6. Invest in a professional, merit-based recruitment process by strengthening the capacities and independence of selection committees, improving selection techniques and ensuring that political discretion does not eclipse the principle of merit in the appointment phase.

7. Continue elaborating and implementing competency frameworks for SCS positions.

8. Invest in the competence of the SCS by offering special training programmes and tailored development activities, and by creating mobility schemes for senior civil servants.

9. Strengthen the role of the central co-ordinating units responsible for the SCS, to offer a professional approach and provide special attention to building a skilled SCS. 


\section{What is a professional senior civil service and how can it be established?}

The discussion on how to build a professional SCS is based on the following definition of the SCS:

Professional civil servants employed in top-level management positions in the national civil service, formally or informally recognised as a separate group. They are competitively appointed to functions that cover policy advice, operational delivery or corporate service delivery ${ }^{12}$.

Some parts of the SCS are usually centrally managed through appropriate institutions and procedures to not only ensure the stability and professionalism of the core group of senior civil servants, but to provide flexibility to accommodate changes in government composition by using appropriate due processes ${ }^{13}$. This study, however, is limited to the following positions ${ }^{14}$.

- Level 1 - managerial positions one level below minister and deputy minister (if a deputy minister-type political appointee is foreseen by law), such as a general secretary, state secretary or permanent secretary.

- Level 2 - managerial positions two levels below the minister and deputy minister (if a deputy minister-type political appointee is foreseen by law), such as general directors, deputy general secretaries, deputy permanent secretaries and heads of sectors.

- Heads of executive bodies subordinate to the government, the prime minister's office and ministries (e.g. executive boards, inspectorates and administrations), such as general directors directly accountable to the government, the prime minister, a minister or a Level-1 senior civil servant. Depending on the management system used, these positions may be equivalent to Level 1 or Level 2 in the managerial hierarchy.

${ }^{12}$ This definition builds on previous definitions of SCS used in the SIGMA 2017 Monitoring Reports; OECD (2017e), SIGMA, Methodological Framework for the Principles of Public Administration, OECD, Paris, p. 96, http://www.sigmaweb.org/publications/MethodologicalFramework-for-the-Principles-of-Public-Administration-November-2017.pdf; and OECD (1995), Top Management Service in Central Government: Introducing a System for the Higher Civil Service in Central and Eastern European Countries, SIGMA Paper No. 1, OECD Publishing, Paris.

${ }^{13}$ OECD (2008a), The Senior Civil Service in National Governments of OECD Countries, Public Employment and Management Working Party, OECD Publishing, Paris, p. 17.

${ }^{14}$ This is aligned with the International Standard Classification of Occupations, classification of top managers used in the Survey on Compensation of Employees in Central/Federal Government in OECD (2017), Government at a Glance, OECD Publishing, Paris. http://dx.doi.org/10.1787/gov_glance-2017-en 
This paper does not address central government political positions (such as ministers, deputy ministers, ministerial advisers and ministerial cabinets), which are covered in SIGMA Paper No. $38^{15}$ and in the OECD report on ministerial advisers ${ }^{16}$. Senior civil servants work closely with political leaders and their teams, so proper functioning of this political layer is also important for the development of a mature merit-based SCS, but the scope of this paper is limited to professional civil servants.

The concept of "professional" in the definition of the SCS refers to two core principles: professional competence and political responsiveness. The fundamental principle is professional competence, which embodies the range of skills, knowledge, attitudes and behavioural attributes that are expected to lead to better performance and integrity in public administration, thereby serving the collective public interest and maintaining stability and trust in public institutions. Professional competency in the SCS concerns not only high-level expert knowledge and managerial skills, but the essential values and behaviours that safeguard the public good and maintain constitutional respect, integrity, impartiality and inclusiveness ${ }^{17}$.

Such competency is most likely to be achieved by following the principle of merit and having an effective institutional set-up. The principle of merit is enduring and indisputable $\mathrm{e}^{18}$, as it ensures a civil servant's professional ethos and competency to execute the job expectations, and helps preserve civil service impartiality and independence from party politics. Applying the principle of merit to civil service appointments means hiring based on qualifications, competence, values and attitudes, and not on discrimination in any aspect, which should result in law-abiding, transparent, ethical and performance-orientated behaviour. A proper institutional framework must be in place, including an appropriate legal framework, functioning systems, work processes and professional capacities, to enforce the merit principle in practice.

At the same time, political responsiveness of the SCS is needed to ensure a functioning democracy ${ }^{19}$. Political responsiveness means that the SCS is committed to professional implementation of the sitting government's policy, which expresses the preferences of the electorate. Senior officials work closely with politicians, so it is

${ }^{15}$ OECD (2007), Political Advisors and Civil Servants in European Countries, SIGMA Paper No. 38, OECD Publishing, Paris.

${ }^{16}$ OECD (2011), Ministerial Advisors: Role, Influence and Management, OECD Publishing, Paris, http://dx.doi.org/10.1787/9789264124936-en.

${ }^{17}$ Matheson, A. et al. (2007), Study on the Political Involvement in Senior Staffing and on the Delineation of Responsibilities Between Ministers and Senior Civil Servants, OECD Working Papers on Public Governance, No. 6, OECD Publishing, Paris, p. 9-10, http://dx.doi.org/10.1787/136274825752.

${ }^{18}$ Randma-Liiv, T. (2016), Civil Service Merit Values Between Employment Security and Flexibility, paper prepared for EUPAN working-level meeting, Brussels, 21-22 January 2016.

${ }^{19}$ Responsiveness of elected officials is widely seen as a legitimate way of being politically responsible to citizens, according to Dunn, D. (1997), Politics and Administration at the Top: Lessons from Down Under, University of Pittsburgh Press, Pittsburgh; and Peters, B.G. and Pierre, J. (2004), The Politicization of the Civil Service in Comparative Perspective: A Quest for Control, Routledge, London. 
important to establish constructive working relationships that maintain the neutrality of the SCS while achieving the acceptance and trust of the politicians. As constructive working relationships between ministers and senior civil servants result in personal trust, they also contribute to smooth management of government organisations.

Political responsiveness does not in any way mean that the SCS has partisan tendencies or is subject to party patronage, favouritism or politicisation. Likewise, senior civil servants should not be considered staff members loyal to the incumbent politician, coming and going with the minister, as this could easily lead to favouritism, a lack of institutional memory and instability. The location of senior civil servants in the political-administrative interface does mean, however, that they are likely to be affected by political influence ${ }^{20}$, which may create tension between the principles of professional competence and political responsiveness. There is a risk that the quest for political responsiveness could lead to politicised incompetence in the civil service, threatening the professionalism of the SCS.

To create an appropriate balance, the concept of a 'public service bargain' has been used to describe the relationship between politicians and senior civil servants. It means that if politicians expect a high level of competence and managerial performance in SCS commitment to delivering the government's political goals, they will reward them with decent compensation, job security and abstention from undue political interference in personnel policy and managerial decision making ${ }^{21}$. Professional competence can easily be jeopardised when the quest for political responsiveness overrules the principle of merit. This is the main reason for enforcing significant restrictions on political interference and discretion in relation to the SCS, and it is particularly important in less-developed political cultures in younger democracies, where political interference must be restricted to promote and safeguard professional competence in the $\mathrm{SCS}^{22}$.

It is important to understand the overall value of having a professional SCS. Having competent and experienced managers in senior positions is associated with greater organisational performance and less corruption in the public sector than when senior positions are staffed by political appointees selected on the basis of partisan loyalty ${ }^{23}$. The superior performance results from several factors, including higher levels of competency and managerial skills, but also from the public service ethos and values needed for serving the public interest, ensuring the rule of law and maintaining policy consistency that are ingrained in professional senior civil servants. A professional SCS is therefore important not only for the stability of institutions and continuity of expert knowledge in the public administration, but for achieving effectiveness and efficiency

\section{${ }^{20}$ OECD (2016), p. 6.}

${ }^{21}$ Hood, C. and Lodge, M. (2006), The Politics of Public Service Bargains, Oxford University Press.

${ }^{22}$ Randma-Liiv,T. (2016).

${ }^{23}$ Lewis, D.E. (2008), The Politics of Presidential Appointments: Political Control and Bureaucratic Performance, Princeton University Press, Princeton, NJ; and Meyer-Sahling, J.H. and Mikkelsen, K.S. (2016), Civil Service Laws, Merit, Politicization, and Corruption: The Perspective of Public Officials from Five East European Countries, Public Administration, Vol. 94/4, pp. 1105-1123. 
in daily administration. The SCS, in its position at the top of the administrative apparatus, is also a model for civil servants and public employees under its command, both in professional competencies and in overall values. Senior civil servants are crucial to safeguarding the integrity of the system, thus any shortfalls in professional ethos and behaviour can pave the way for corruption at lower levels.

Because senior civil servants have a crucial role in preparing and implementing public policies and important reforms ${ }^{24}$, and in effectively delivering services to citizens and businesses, their competency influences achievement of the government's policy goals, trust in the government and attractiveness of the business environment. Figure 1 summarises the value of building merit-based SCS, with competency and responsiveness shown as key inputs on the left. The middle box represents essential outcomes, and the wider impacts are shown on the right.

Figure 1. The value of a merit-based senior civil service

\section{Inputs \\ Outcomes \\ Impacts}

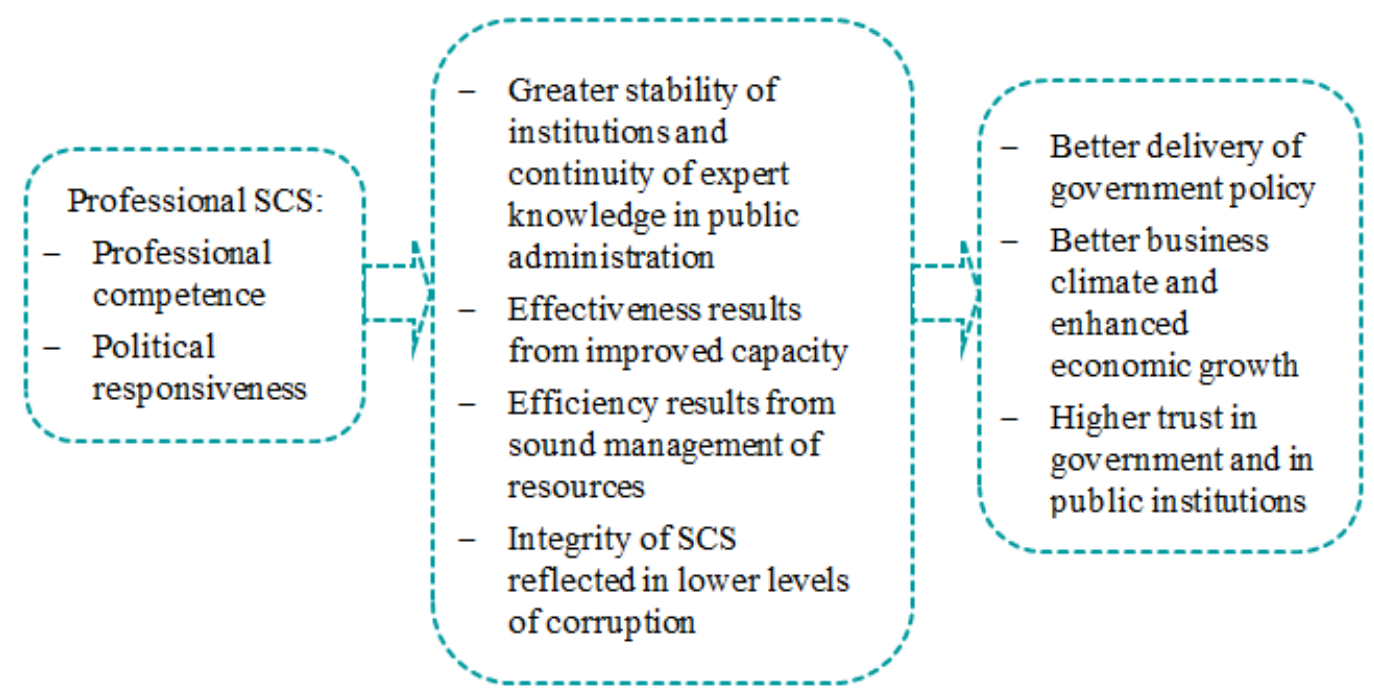

Sources: SIGMA, adapted from Matheson, A. et al. (2007), Study on the Political Involvement in Senior Staffing and on the Delineation of Responsibilities Between Ministers and Senior Civil Servants; and Kuperus, H. and Rode, A. (2016), Top Public Managers in Europe: Management and Employment in Central Public Administration.

As much as a professional SCS embodies the principles of professional competence and political responsiveness, it must be recognised that there are different institutional frameworks and practices that can be used to deliver these principles and hence to achieve professionalisation of the SCS. For example, the experiences of different EU member countries demonstrate a considerable variety of institutional solutions leading to professionalisation of the SCS. Which systems are

${ }^{24}$ Kuperus, H. and Rode, A. (2016), Top Public Managers in Europe: Management and Employment in Central Public Administration, Ministry of the Interior and Kingdom Relations, The Hague, p. 9. 
needed to ensure both competence and responsiveness depends predominantly on the local context and, more generally, on the characteristics of the civil service system as it outlines recruitment, selection and training procedures. In career-based systems ${ }^{25}$, senior civil servants are typically recruited from inside the civil service, where their prior experience and special training in designated schools of public administration ensure that they have accumulated professional competences. In position-based systems $^{26}$, SCS positions can be attained by those with no prior civil service experience. Whereas in career-based systems, the recruitment and selection process can rely heavily on easily obtainable information on previous experience and the proven performance of internal candidates, the position-based model requires different and more elaborate recruitment, testing and on-the-job training. Each country should be encouraged to develop its own institutional configuration, as long as it ensures professional competence and prevents undue political interference to avoid degeneration into a system of politicised incompetence.

This chapter focuses on the main components needed for building a professional SCS using the analytical framework which elaborates further the Principles of Public Administration. First, the analytical framework describes the essential components of a professional SCS, which could also be helpful for developing further the institutional set-up of SCS management in a number of countries that are reforming their public administration. Keeping in mind the context of ongoing reforms and active statebuilding in these Western Balkan administrations, this study focuses on the crucial elements needed for professionalisation of SCS in young democracies and deliberately does not address topics which are relevant for more advanced, mature systems, such as work-life balance, leadership development or mobility schemes. While the key components and expected results are briefly visualised in each subsection, Annex 1 provides a full description of the components. Second, the analytical framework was also used as a methodological basis for analysing the current situation of SCS in the Western Balkans (Chapter 2).

\subsection{Senior civil service composition and employment conditions}

Clear delineation of the SCS in terms of composition, roles and responsibilities, and accountability lines not only reinforces the boundaries between professional seniorlevel officials and elected politicians and their political appointees ${ }^{27}$, but also

25 A "lifetime civil service", in which a career starts at the lowest level and throughout the career one can be promoted in the hierarchy based on merit. The aim is to build a coherent civil service with common values and a working culture shared across the civil service, which favours mobility and makes working across government organisations easier. Centralised civil service rules, management bodies and training systems ensure equal treatment, professional growth and stability.

${ }^{26}$ Also called open systems, in which SCS positions are open to people within and outside the civil service (private sector, academia, etc.). Suitability for the job is valued and such systems aim at a larger choice of candidates, cultural renewal, promotion of competition and strong performance orientation. Such systems enable decentralisation of recruitment and differentiation of employment and pay conditions in accordance with the organisation's needs and the market situation.

${ }^{27}$ Pollitt, C. and Bouckaert, G. (2004), Public Management Reform: A Comparative Analysis, 2nd edition, Oxford University Press; EC (European Commission) (2015), Quality of Public 
safeguards the institutional continuity and sustainability of public policy programmes and institutions. The creation of a separate SCS group also cultivates a shared identity and collective SCS ethos, breaking down the classic isolation ('silo structure') of the public administration, strengthening the whole-of-government approach and clarifying boundaries between politics and administration ${ }^{28}$. Other factors, such as the small size of the SCS group, networking opportunities and internal mobility, also enhance homogenous SCS identity ${ }^{29}$.

Figure 2. Key components and expected results of appropriate senior civil service composition and employment conditions

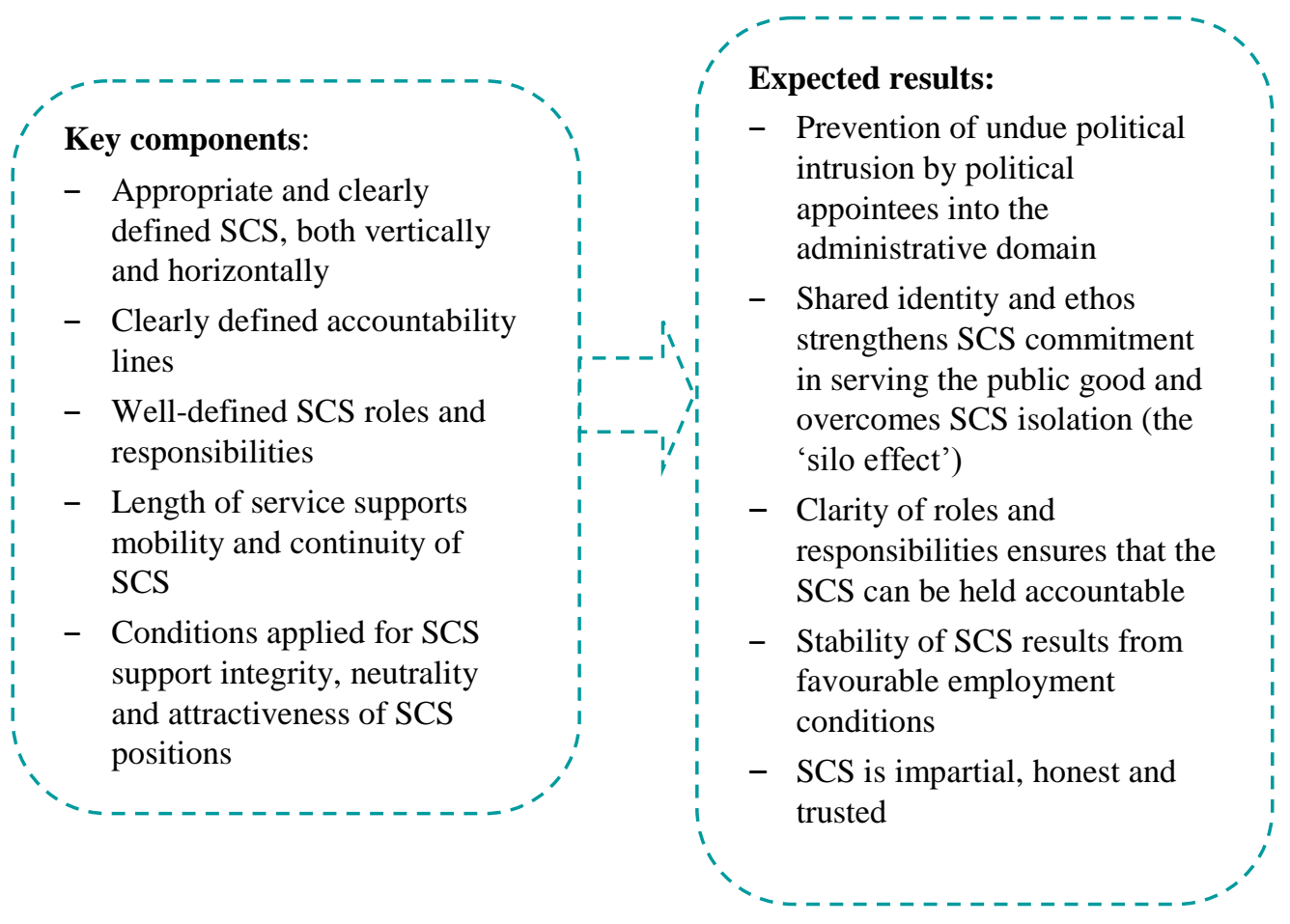

The experience of EU member countries shows that there are several ways to create differentiation of the SCS. It can be done by either creating a formal SCS legal status and/or by having special conditions (recruitment procedures, benefits, length of service, etc.) for senior civil servants ${ }^{30}$. Professionalisation of the SCS does not

Administration: A Toolbox for Practitioners, Publications Office of the European Union, Luxembourg.

${ }^{28}$ Randma-Liiv, T., Uudelepp, A. and Sarapuu, K. (2015), From Network to Hierarchy: The Evolution of the Estonian Senior Civil Service Development System, International Review of Administrative Sciences, Vol.81/2, pp. 373-391; and OECD (2008b), The State of Public Service, OECD, p. 71.

${ }^{29}$ EC (2015) Quality of Public Administration: A Toolbox for Practitioners, Publications Office of the European Union, Luxembourg, p.165.

${ }^{30}$ Most EU member countries have chosen to create special conditions for the senior civil service, with 14 countries having a special top civil service status in their legislation (Kuperus and Rode, (2016), p. 17). 
inevitably require the creation of a distinct legal status for this group, as it can also be achieved by differentiated recruitment, performance assessment and appraisal, and training and development systems. Trends in EU member countries since 2008 indicate a movement towards acknowledging the differences between SCS work and that of the general civil service through formalised SCS schemes and more centralised elements in SCS recruitment and selection ${ }^{31}$.

Clarity of composition and scope can be achieved by appropriately defining the SCS, both in vertical and horizontal terms. Vertically, the SCS mediates between political positions (political executive appointees, political advisors) and civil servants. Vertical scope refers to the number of layers in the hierarchy that are included in the SCS: in most EU countries, the SCS vertical scope usually covers two or three levels below the highest political position ${ }^{32}$. Horizontally, the SCS bridges different policy sectors and types of public institutions through shared values and competencies related to executive management, policy advice and policy implementation. Considering a wide spectrum of governmental organisations in different countries, both inside and beyond the central government executive, there is no common standard to delineate the SCS horizontally. However, the deliberate design of the horizontal scope of the SCS can be used as a means to co-ordinate and consolidate different parts of the public administration for a more coherent single-government approach. An inclusive horizontal scope of the SCS is therefore desirable, and may also cover senior managerial positions in other branches of power, not just within central government. However, the horizontal scope of the SCS cannot be dealt with separately from the rest of the civil service; this issue therefore has wider implications and concerns the construction of the entire civil service. This study limits the scope of analysis in Chapter 2 to the executive branch.

Overall, the size of the SCS differs across countries, with both the size of the country and of the civil service being determining factors. Still, the SCS should be rather small to both reinforce the meaning of managerial apex and to create a common ethos and enable operational co-ordination more easily ${ }^{33}$.

Clarity in accountability lines is a precondition for proper oversight and control over the work of senior civil servants. Lines of accountability must be transparent and mutually respected, as must be the decisions, processes and responsibilities of senior civil servants and political positions. Well-defined roles and responsibilities are also needed to avoid undue political intrusion into administrative domains that can result in partisan loyalty displacing professional competence and merit ${ }^{34}$. Clarity of accountability is undermined or blurred when political appointees (such as chiefs of cabinets, political advisors, etc.) take over managing roles in ministries and hence give direct administrative orders to professional civil servants at different levels. Instead, such political appointees should report to the minister only, and should follow the clearly-established managerial accountability lines of the organisation.

\footnotetext{
${ }^{31}$ Idem, p. 18.

${ }^{32}$ Idem, p. 15

${ }^{33}$ EC (2015), p.164.

${ }^{34}$ Matheson et al., (2007).
} 
Clear accountability lines and distinct roles and responsibilities also provide managerial autonomy and decision-making freedom for senior civil servants. This is essential to attract professionally qualified candidates to SCS positions, and to create conditions under which senior civil servants are willing to take personal responsibility.

Factors such as political instability, weak governance institutions and major ideological shifts after elections tend to increase the desire of governments to politically control the civil service by means of appointments ${ }^{35}$. This pattern is reflected in high turnover rates after changes of government that threaten the stability and continuity of the SCS; in this context, it is important that overall SCS employment conditions serve as a protection against undue political interference. The employment conditions of the SCS need to not only support the neutrality, stability and integrity of the SCS, but create an environment which high-performing and competent people want to work in. Such conditions can be created through lengths of appointments, requirements and restrictions applied to SCS positions, and in the remuneration system. Ultimately, these conditions translate into wider trust and legitimacy to serve the collective public interest and secure the rule of $\mathrm{law}^{36}$.

As senior civil servants play an important role in ensuring constitutional respect and institutional continuity of the public administration despite changes in government, they should have sufficient job security and be protected against politically motivated replacement. Thus, when the length of service is fixed for the SCS, it should not be connected to the term of the government in office, to avoid high turnovers that break continuity and erode institutional memory after changes of government.

Although in many EU member countries appointments are for an indefinite term, some countries use fixed-term appointments, especially for the position of general secretary of a ministry ${ }^{37}$. Despite the model used - indefinite term or fixed-term appointment - it should include an efficient performance review system and ensure mobility of senior civil servants, to retain experience and promote a whole-of-government way of working. If well-designed and properly implemented, either of the models can be used for building a professional SCS.

Whereas the advantages of appointments based on tenure are well documented, as these derive from the traditional Weberian public administration model, it is important to counterbalance and minimise potential negative side-effects of fixed-term contracts. These include lower stability, higher risk of politicisation, and the threat of political manipulation for employees wanting to be considered loyal enough for contract renewals or new appointments. It is therefore essential to have conditions and systems in place to guarantee that increased instability is compensated by protective measures that ensure talent is not lost after the term ends. To manage the potential risks, fixedterm appointments should be used only for some - not all - SCS positions. This study does not give preference to either model, as they both have their strengths and weaknesses, but it must be ensured that the approach used is able to balance the

35 Meyer-Sahling, J.-H. and Veen, T. (2012), Governing the Post-Communist State: Government Alternation and Senior Civil Service Politicisation in Central and Eastern Europe, East European Politics, Vol. 28/1, pp. 4-22.

${ }^{36}$ Matheson et al., (2007), pp. 9-10.

${ }^{37}$ Kuperus and Rode, (2016), p. 26-31. 
various needs, such as stability versus motivation, and job security versus performance.

Regarding restrictions and requirements, their main purpose is to maintain neutrality and integrity by preventing conflict of interest. These conditions are usually applied for the civil service overall, not just for the top layers, but in some cases more demanding requirements and tighter restrictions may be enforced at the SCS level because its decisions are very influential and the extent of potential harm in case of misconduct is great (for example, threats to application of the rule of law, financial damages and reduced trust in/legitimacy of public institutions).

SCS employment conditions also include pay and benefits, which must be stable and fair, although this is not the only way to attract and retain qualified people. Nonmonetary factors such as professional advancement prospects, interesting and challenging job content, intrinsic motivation and the overall ethos of the SCS are major motivating factors for a career in the $\mathrm{SCS}^{38}$. In the Western Balkans, employment stability is also an important factor. As the SCS requires high-performing, experienced leaders, differentiated remuneration schemes are often used to attract and retain competent people in these positions. A harmonised and transparent salary system also contributes to the mobility and equal treatment of senior civil servants. However, a merit-based system of career development can act as a powerful performance incentive on its own.

Although the wider topic of transparency and sufficiency of remuneration should not be overlooked, SIGMA's experience has shown that this is not the most problematic issue in the Western Balkans. Moreover, the issue of salaries is very complex given the specific legal framework of each administration and it would require a separate study to draw meaningful conclusions. The topic of remuneration is therefore excluded from the scope of data collection and analysis in Chapter 2.

\subsection{Recruitment and selection}

Efficient recruitment and selection systems are critical for establishing a professional SCS, as their ultimate purpose is to appoint managers that possess high-level professional competences. Because of the great impact of senior civil servants' work, advanced professionalism and managerial skills are required.

As senior civil servants operate where the civil service and the political sphere meet, one of the greatest challenges in building a professional SCS is maintaining the balance between political responsiveness and trust, and neutral competence. Politicians may wish to influence selection and appointment decisions, but this should be allowed only after the level of professional competence has been verified. If politicians value competence, and if they want the SCS to be both professional and responsive, they should confirm this by not interfering in merit-based selection procedures.

${ }^{38}$ Idem, p. 26; and Van Wart, M., Hondeghem, A. and Schwella, E. (eds.) (2014), Leadership and Culture: Comparative Models of Top Civil Servant Training, Palgrave Macmillan, pp. 7388. 
Figure 3. Key components and expected results of merit-based recruitment and selection of senior civil servants

Key components:

- Clear, non-discriminatory and appropriate eligibility criteria

- Approachable, reasonable and transparent application process through competition

- Relevant professional competency profiles to communicate expected performance and competencies needed

- Merit-based recruitment and selection through competition

- Selection criteria relevant for SCS positions

- Testing methods that comprehensively screen professional competence

- Professional, neutral and well-informed selection committees

- Transparent and timely appointment, ensuring both principle of merit and political acceptance

- Effective appeal system ,

,

: $:$ Expected results:

Robust systems and sufficient measures are therefore needed to deliver professional quality and fair selection and to clearly circumscribe when and how much political discretion may be exercised while maintaining political acceptance of a merit-based appointment process. The systems of recruitment, testing and selection must be based on professional human resource management (HRM) practices and be thorough enough to ensure that selected candidates are able to adequately perform their duties. Such systems would be trusted to attract good candidates and considered legitimate by both politicians and the general public.

The choice of the recruitment and selection system for the SCS depends partially on whether a career or position-based system is in place. Most Western Balkan administrations have a hybrid or position-based system, meaning that entry into the SCS is possible from both inside and outside the civil service. In practice, it means that Western Balkan administrations need to build a truly professional recruitment and selection system to ensure that shortlisted candidates are fit for the job. In such a system, all three phases - application, assessment and selection, and appointment must be transparent, neutral and based on good HRM practices.

In the application phase, numerous factors must be kept in mind to ensure equal access, transparency and efficient application procedures. First, a competitive entry process is one of the key preconditions for following the merit principle in the recruitment process. Second, clear, non-discriminatory and relevant eligibility criteria should be used to ensure that access to SCS positions is possible for all qualified 
candidates. And third, the application process must be kept approachable and simple enough to encourage good candidates to apply. Public advertising of SCS vacancies through visible and multiple channels also signals openness and opportunities for equal access, so it makes economic sense to invest in user-friendly websites for announcements and applications. It is also important to allow sufficient time for document submissions and to avoid excess application burdens and costs.

Equal access to SCS positions also means that the SCS is gender-balanced and reflects the composition of the society at large. A policy of workforce diversity and inclusiveness means that ensuring equal access and fair treatment of candidates is important for attracting qualified people with a wider range of skills, but also for building a positive employer image ${ }^{39}$. While management of diversity is becoming more and more important ${ }^{40}$, most of the EU countries target gender diversity and disabilities in their human resource strategies ${ }^{41}$. This paper is limited to addressing gender balance only, for two main reasons. First, in many countries women are the biggest under-represented group in SCS positions and evidence shows that they continue to face great difficulties in accessing senior management positions ${ }^{42}$. This is despite the trend of female graduates outnumbering male ones, implying that female applicants are generally more educated than male applicants ${ }^{43}$. Lower female representation in the SCS increasingly indicates underused human potential. Moreover, studies suggest that gender equality in teams correlates with innovation potential and with better organisational and financial performance ${ }^{44}$. Second, gender balance is an area for which data is available for both the EU and the Western Balkans. However, diversity measures for inclusion of other under-represented groups, is also important. Given that the public sector is a significant employer, its human resource policies inevitably have a wide impact on the employment market and workforce inclusiveness. The civil service, including the SCS, can therefore lead by example to bring down the barriers for women and other under-represented groups to enter senior positions through competitive recruitment.

The assessment phase is the most difficult, as it involves checking candidate qualifications to ensure those shortlisted have the ability to perform the duties. It is important that selection criteria be clear and relevant, so that it is evident which qualities need to be checked and tested during the selection process. The practices of

${ }^{39}$ OECD (2017a, p. 73.

${ }^{40}$ Idem, pp. 72-74.

${ }^{41}$ Kuperus and Rode, (2016), p. 73.

42 OECD (2014), Women, Government and Policy Making in OECD Countries: Fostering Diversity for Inclusive Growth, OECD Publishing, Paris, p. 65, http://dx.doi.org/10.1787/9789264210745-en.

${ }^{43}$ EC (2016), Report on Equality Between Men and Women 2015, cited in Kuperus and Rode, 2016, p. 73.

${ }^{44}$ For example: Gratton, L. et al. (2007), Innovative Potential: Men and Women in Teams, Executive Summary, The Lehman Brothers Centre for Women in Business, London Business School, London; McKinsey and Company (2013), Women Matter 2013-Gender Diversity in Top Management: Moving Corporate Culture, Moving Boundaries, www.mckinsey.com/features/women_matter; OECD, (2014). 
EU member countries combine a wide range of criteria: years of professional experience; qualifications and competencies required for a specific position; basic mandatory requirements for entering the civil service (such as citizenship, education level, no criminal record); core qualifications and competencies for the SCS (such as leadership skills); education; career progression; and performance assessments ${ }^{45}$.

It is essential to clearly understand which specific competencies are needed for the SCS. The term competency covers both the competence characteristics (knowledge and skills) and the commitment characteristics (values, motivation, self-awareness, etc. ${ }^{46}$. As not all competencies needed for the job can easily be developed, the recruitment process must ensure that appointees have the right mix; this is why an increasing number of countries have elaborated competency models ${ }^{47}$. Competency models can be used not only for recruitment and selection to communicate which competencies are needed and to provide a basis against which candidates are tested, but can also inform training and development, and performance assessment ${ }^{48}$.

As SCS positions require a complex mix of competencies, it is important that these qualities be checked and measured in the selection process using a combination of testing methods that have a strong predictive value. Although it is easier to assess certain competencies through oral methods and others through written, usually the best predictive value comes from a combination of different assessment methods ${ }^{49}$.

Clearly, merit-based recruitment and selection also requires competent selection committees, which are often used to ensure political impartiality and objectivity in the recruitment process $^{50}$. Committee neutrality and professionalism (including the understanding and expert skills for using various selection methods) can be ensured through different institutional solutions. For example, thirteen EU member countries use central selection committees, and 12 employ a decentralised approach wherein the selection process is conducted by the ministries ${ }^{51}$ (but usually official guidelines and criteria still ensure the quality of selection).

The final phase of recruitment is appointment, which is effective when it results in properly filling positions with competent people in a timely manner, while maintaining

45 Kuperus and Rode, (2016), p. 39.

${ }^{46}$ Linkage, (1997), and Khanka, (2006), cited in Kuperus and Rode, (2016).

47 A competency model is both a list of required competencies and a tool for expressing, assessing and measuring them. A fully developed competency model includes clusters of competencies, descriptions of the competencies that make up each cluster, definitions of each competency, and several behavioural indicators for each competency (op de Beeck and Hondegem, (2010), cited in Kuperus and Rode, (2016), p. 41).

${ }^{48}$ In 2015, 18 EU member countries used competency profiles for recruitment and selection, 13 for performance appraisal and 10 for training and development (Kuperus and Rode, (2016), p. 43).

49 Schmidt, F.L. and Hunter, J.E. (1998), The Validity and Utility of Selection Methods in Personnel Psychology: Practical and Theoretical Implications of 85 years of Research Findings, Psychological Bulletin, Vol. 124/2, pp. 262-274.

${ }^{50}$ Kuperus and Rode, (2016), p. 34.

${ }^{51}$ Idem, p. 35. 
political acceptance. Due and proper filling of positions also guarantees that the number of acting senior civil servants is kept to a minimum, their terms are strictly limited, they are appointed from among existing civil servants, and a possibility to nominate acting heads does not in any way overrule merit-based recruitment and selection but, rather, provides a temporary solution to a vacancy problem until such time as a merit-based appointment can be made.

It is only at this point in the recruitment process that the role of politicians can be considered. They may be given the opportunity to select a candidate from a preselected list, either the top-ranked or any from the list. Either way, the key is to have selected competent candidates in the pre-selection stage, meaning that recruitment and selection should be thought of as a sequence of steps or stages. If the first stages effectively filter applicants, it is no problem to allow politicians the final selection. The role of politicians in the appointment phase is to ensure political acceptance of the SCS, reflecting political accountability for SCS appointments and signalling constructive co-operation at the political and senior management levels. Whereas wellestablished democracies may allow slightly more political involvement because of their stronger embedded values, social control measures (the press, non-governmental organisations [NGOs], etc.) and institutionalised professional SCS management systems, it is important that new democracies ensure that political discretion in the appointment phase be transparent and limited ${ }^{52}$. In some EU countries, the role of politicians in choosing candidates is purely formal, as they simply confirm the first choice of the professional and neutral selection committee, while in others ministers can choose from among two or three shortlisted candidates picked by the selection committee ${ }^{53}$.

Finally, an appeal system must be in place to safeguard the equal treatment of candidates during recruitment and selection. A well-functioning appeal procedure also contributes to overall trust in, and legitimacy of, the recruitment system.

\subsection{Professional development and training}

The delivery of public services or implementation of PAR is highly dependent on human labour. This, in turn, depends on how managers - senior civil servants - engage and motivate their staff to achieve desired goals. While the recruitment and selection system is crucial to ensure that people with the right set of competencies are appointed, it is rare that a selected candidate fits the job requirements entirely. In addition, changes and new challenges in public administration demand constant learning and active self-development of senior officials.

\footnotetext{
${ }^{52}$ Idem, p. 25.

${ }^{53}$ Idem, pp. 23-25.
} 
Figure 4. Key components and expected results of senior civil service professional development

Key components:
Professional development of
SCS in place

The overall approach to professional development depends in part on the civil service model present in a country. In career-based systems, the main development needs are usually related to managerial and leadership competencies, as the candidates come from within the civil service and already possess knowledge of how the government operates. Hybrid and position-based systems have different needs, as training and professional development must be suitable for external recruits who have neither prior civil service experience nor special education (but bring other relevant skills and experience to the job). It must also be kept in mind that public management has distinct characteristics (i.e. political dynamics, a policy making process, a legal environment, a budgetary process, etc.) not always present in the private sector that need to be considered when professional development systems are designed for senior civil servants.

Part of making senior civil servants a distinct group - and providing the impetus for a joint training and development system for the SCS - are the wider aims of cultivating shared values, stimulating collaboration and networking, promoting a whole-of-government approach, and supporting mobility and cross-fertilisation ${ }^{54}$. Joint professional development of senior civil servants encourages exchange of ideas among peers, provides opportunities to learn from one another, and requires specially tailored executive-level training programmes and methods to be used. This approach recognises that senior civil servants are not just a group of individuals whose personal performance is important, but that together they form a level necessary for a highperforming public administration. Overall, a centralised and integrated development approach is both effective and efficient.

To address both the individual development needs of each senior civil servant and to contribute to the collective ethos and joint working culture of the SCS, a solid foundation of professional development and training is needed. As discussed in Section 1.2, competency models can provide a basis for planning development and

${ }^{54}$ EC (2015), p. 165. 
training activities. Today, professional training and development not only focuses on obtaining specific knowledge, but is increasingly used for advancing the general competencies of the SCS, such as analytical skills, strategic thinking, social and interpersonal skills, leadership skills, goal achievement, information technology (IT) skills, etc ${ }^{55}$.

Professional development itself is a rather fluid term and can include various types of activities, such as group and individual training, workshops, specially designed development programmes, experience-sharing, mentoring and coaching. In tailoring training to SCS needs, it is important both to select the right training and development methods and to design appropriate content. Because SCS work is highly intensive, professional development activities offered to senior civil servants must be acknowledged by the SCS to encourage active participation. Central co-ordination and organisation of activities will allow time for preparation and for new topics to be brought forward to prepare the SCS for future public administration needs, which probably would not be possible if individual senior civil servants were responsible for enhancing their own professional skills.

This study also includes performance appraisal ${ }^{56}$ under professional development, as it provides ultimate proof that the professional development system is improving managerial performance. Although performance appraisals may also be linked to other HRM areas (such as salary, transfers and dismissals), only its use for professional development purposes is addressed here. A well-functioning performance appraisal system provides valuable feedback for senior civil servants and guides their further development, but also encourages professional achievement. Depending on the maturity of the system, performance appraisals may be kept simple to provide basic regular feedback only, or may be linked with the system of performance pay or designed to meet broader goals, such as alignment with strategic planning of the government.

\subsection{Termination of employment}

Grounds for termination of employment, along with disciplinary procedures, affect the overall working conditions of civil servants. As senior civil servants are exposed to risks of politicisation and favouritism, objective grounds for dismissal, demotion and disciplinary procedures protect the wider constitutional order and rule of law. Sufficient job security and protection against discrimination or unfair dismissal allows senior civil servants to fulfil their duties impartially and to be responsive both to the sitting government and to citizens.

\footnotetext{
${ }^{55}$ Kuperus and Rode, (2016), p. 57.

56 A methodology and set of procedures for rating the work performance of individuals according to the standards and criteria applied across one or several organisations in a similar fashion (OECD, 2008b).
} 
Figure 5. Key components and expected results of termination of office in the senior civil service

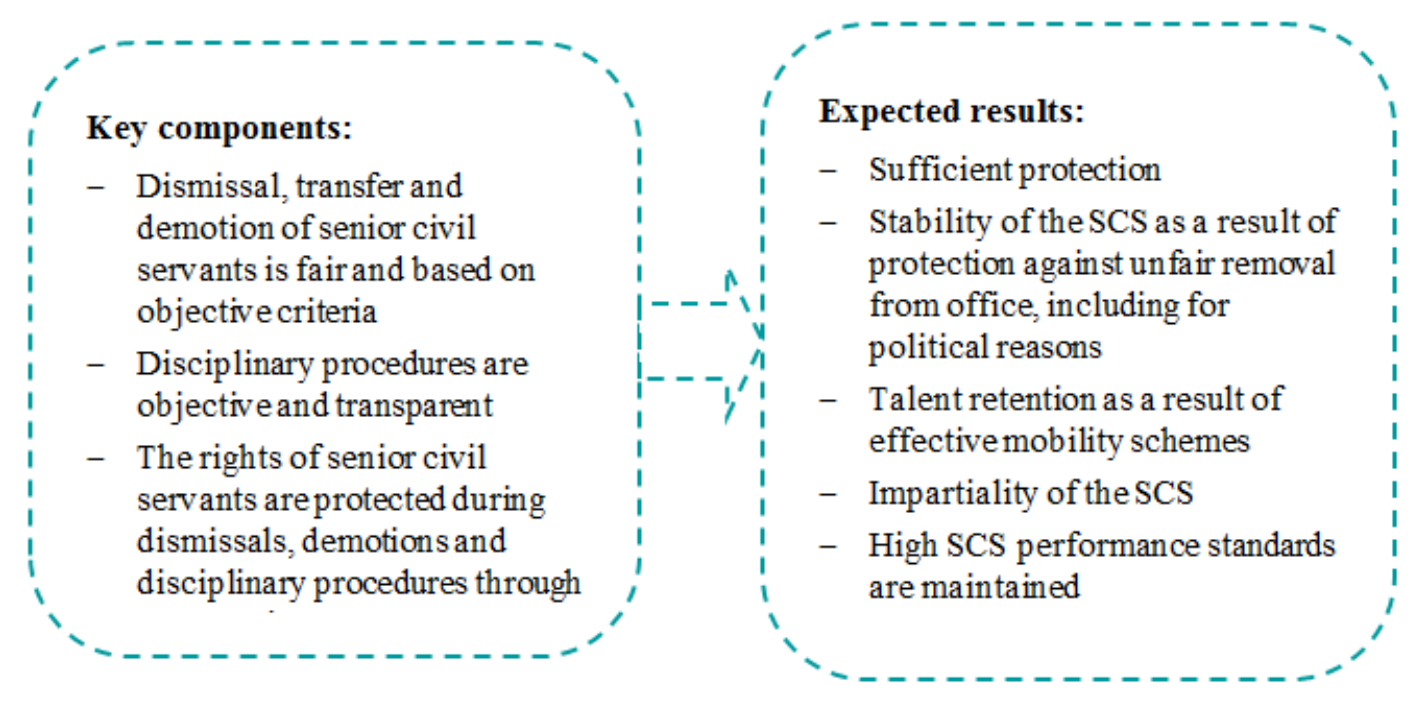

Fair and objective dismissal, transfer (both desired and undesired) and demotion criteria, along with transparent and well-recorded procedures, contribute to professionalisation of the SCS in two key ways. First, they provide a measure for job protection and SCS stability, and second, the grounds for termination of office can also help set high standards of performance. Fair and objective criteria deliver the message that positions are not granted for an indefinite period time, but depend on quality of performance.

Conditions of termination of office must be considered together with length of appointment (addressed in Section 1.1), as well as what happens after service term expiry or termination of employment by any other means. Fixed service terms create a natural turnover and provide the opportunity for non-renewal of employment of officials whose performance and competencies have not been satisfactory. To maintain stability and retain talent, however, well-managed mobility schemes should allow senior civil servants to advance their careers in the civil service. Grounds for dismissal and demotion, decent compensation schemes and mobility opportunities are therefore important considerations in the design of SCS work conditions.

SCS work sometimes involves situations in which employees need to contravene the political orders of their superiors to protect application of the rule of law, ensure that coercive power used is proportional, or warn against short-sighted or unaffordable policy decisions. Thus, conditions and terms of termination of office should be in place that provides sufficient material and reputational protection for officials in case of politically-driven removal from office.

Although this section's focus is on grounds for termination of employment, disciplinary procedures are briefly addressed because they could easily be misused. Serving political motives, disciplinary actions could be used to threaten senior officials and make them obey political orders, despite their illegality.

The confidence offered by job security and legal protection against unfair termination of employment or sanctioning through disciplinary procedures is what allows the SCS to work in the neutral, impartial and law-abiding manner necessary to ensure the 
public good and constitutional respect. Such a working environment also strengthens the self-esteem and ethical convictions of senior civil servants, allowing them to take pride in their job and assume the responsibility it entails.

Finally, an appropriate, functional appeal process must be in place to make the system comprehensive and protect employees against illegal and unfair dismissals, demotions and disciplinary procedures.

\subsection{Senior civil service policy co-ordination and management}

As in any other policy area, the creation of a professional SCS requires consistent and well-developed policies, and the institutional capacity to implement them. Good management of senior civil servants should follow an integrated approach whereby they are treated as a priority group by the government, whose members perform similar tasks and therefore have similar developmental needs. Senior civil servants need to be invested in and developed together so that they share common values and obtain the skill sets needed to manage public organisations, and central management provides more flexibility for government and enhances mobility for the SCS. Another argument for central management of the SCS is prevention of political interference that can happen at the level of individual ministries, especially concerning promotion, demotion and pay for performance ${ }^{57}$.

Figure 6. Key components and expected results of senior civil service policy co-ordination and management

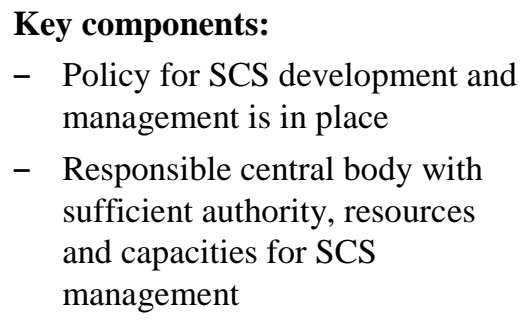

\section{Expected results:}

- Professionalisation of the SCS is supported and enabled through proper management

- Implementation of SCS policy results in a high-performing public administration

A policy for professionalising the SCS can be elaborated as part of public administration or civil service reform policies, or may be prepared as a separate, standalone policy document. Whatever the format, it should clarify SCS policy objectives and serve as a legitimate basis for long-term political commitment to build a meritbased SCS. Even if the principle of merit and an institutional framework with relevant legal provisions, institutional set-up, resources and capacities have been put in place, there are no guarantees against reversal of such reforms; thus, it is important to maintain and constantly renew wider consensus for and acceptance of a professional SCS.

Building a professional SCS requires time and consistency: the experiences of countries that recently joined the EU suggest that it may take a decade or more to

${ }^{57}$ OECD, (2008a). 
reach consensus on SCS management practices, elaborate the content of SCS policy, and create the necessary institutional framework and capacities ${ }^{58}$. In fact, in many new EU member countries, SCS management practices remain subject to change even today.

Each policy must have a responsible owner to ensure that it is properly implemented and further developed. The process should begin with elaboration of relevant policy content (policy document, plans of implementation) and the establishment of necessary systems and processes for daily operational management. Centralisation of SCS management, at least in part, increases the consistency of management practices and helps to reduce politicisation; it also raises the profile and perceived importance of SCS management. This will increase political, administrative and external (media and civil society) attention and, presumably, willingness to support SCS professionalisation.

Again, the choice of institutional set-up may differ across countries. While some have decided on a central responsible body (for example, the Netherlands and Estonia), others (Portugal and Slovenia) have allocated special roles and responsibilities to a designated unit within the overall civil service management and co-ordination body. In the latter case, a special team or a person competent in SCS development must be in place to cater to the needs of the differentiated recruitment/selection and training/development systems. The foregoing sections have indicated that active involvement of a professional team responsible for SCS management is very valuable in selection and recruitment (Section 1.2) as well as training and development (Section 1.3). It is also presumed that a senior civil servant who can be identified as the head of the civil service will be responsible for managing the SCS, but not as their superior. This responsible unit or body needs to have sufficient capacity, authority and resources to keep the necessary systems functioning professionally.

58 Uudelepp, A., Randma-Liiv, T. and Sarapuu, K. (2013), Coordination Practice: Development of the Estonian Senior Civil Service, COCOPS. 


\section{Senior civil service in the Western Balkans}

All of the Western Balkan public administrations studied here - Albania, Bosnia and Herzegovina (BiH State level, the FBiH and the RS), Kosovo, the former Yugoslav Republic of Macedonia, Montenegro and Serbia - are relatively young independent democracies. Most of them (except Albania) have roots in the Yugoslav state tradition and therefore share some common characteristics.

First, the administrative tradition in these countries is strongly hierarchical and decision-making power is vested in the highest position in each ministry (i.e. the minister). The SIGMA 2017 Monitoring Reports demonstrate that none of the countries has made considerable progress in establishing legislation granting senior civil servants clearly defined and independent decision-making rights in the management of resources, i.e. recruitment decisions, procurement decisions and replying to public information requests. This means that senior civil servants are not empowered to manage the administrative domain.

Second, Western Balkan political culture tends to be clientelistic rather than programme-based ${ }^{59}$. Due to a weak private sector, the public sector is a major provider of jobs, which means that it is in the interest of political parties to offer jobs to their supporters. Interviews with representatives of different stakeholders in these countries do, indeed, suggest that political connections are often considered to be much stronger determinants for hiring decisions than professionalism ${ }^{60}$. From a civil servant's perspective, if party adherence is considered a stronger factor in career advancement than a high level of professionalism is, there is little incentive to continually invest in personal development.

However, if political parties cannot rely on a well-functioning bureaucracy, they may find it increasingly difficult to make credible pre-election promises that can be accomplished after their election, which in turn inhibits their prospects of re-election as well as their incentive to pursue programmatic policies.

Third, there is a discrepancy between the formal rules (which are adequate in most of the countries regarding the civil service) and practices (which deviate from the intention of the law). One of the conclusions of the SIGMA paper "Civil Service Professionalisation in the Western Balkans" is that:

${ }^{59}$ For a discussion on the effects of bureaucratic autonomy on the rise of programmatic parties, see Dahlström, C. and Wängnerud, L. (2015), Elites, Institutions and the Quality of Government, Palgrave Macmillan.

${ }^{60}$ On the importance of political and other non-merit criteria such as belonging to particular ethnic and social groups, see Meyer-Sahling, J.-H. et al. (2015), Improving the Implementation of Merit Recruitment Procedures in the Western Balkans: Analysis and Recommendations, ReSPA Publications, Danilovgrad, Montenegro. 
"the main weakness of civil services in the Western Balkans is the lack of rule effectiveness. Even if formal civil service rules exist and are routinely implemented, they often fail to achieve the outcomes that they were meant to achieve. The lack of rule effectiveness is particularly pertinent in the domains of senior civil service management, integrity management and performance management. The same weaknesses apply to the areas of recruitment and civil service training, albeit to a lesser extent ${ }^{,}, 61$.

For further professionalisation of the SCS, relatively little can be obtained by solely changing the rules without some incentive for the political elite to refrain from controlling the bureaucracy. Chapter 3 builds on the analysis of current practices in different SCS areas in Western Balkan administrations and suggests policy options to overcome the problems.

\subsection{Senior civil service composition and employment conditions}

\subsubsection{What constitutes the senior civil service in the Western Balkans?}

For the purposes of this paper, SCS is generally conceptualised as the officials located one or two levels below the minister, covering both the general management and policy development functions. Depending on the management model of the ministry (see section 2.1.3.), these positions may either be on the same level directly under the minister, or two levels below the minister. In the case of a subordinate body, SCS is considered to reach one or two levels below the minister, depending on the administrative structure of the country. In subordinate bodies, it may be justifiable to consider deputy heads as part of the SCS in countries in which the head of an administrative body is politically determined. This definition has no normative value in and of itself because there is no rule on how the concept of the SCS should be constructed, but this scope has been chosen because these are the positions that stand between the political realm and the rest of the civil service. Moreover, these are the positions in which strategic management and policy development powers should be vested, essential for assisting the government to fulfil its political mandate and provide properly functioning state institutions and public services.

This definition leaves officials in political positions, such as deputy ministers and political advisers, outside the scope of this analysis. Although the political advisers routinely employed by all Western Balkan administrations play an important role in assisting ministers in their work, they are not supposed to be involved in managerial tasks. If, however, political advisers were ever assigned managerial roles within ministries, this would considerably undermine the accountability relationships within the ministry. To give a sense of this group's size, in Albania there are approximately 135 political adviser positions across all ministries, which exceeds the number of senior civil servants in the country $(115)^{62}$.

In terms of the horizontal scope of the SCS, it is expected that at least the heads of the bodies exercising public authority under the government (directly accountable to ministers or to the prime minister) would be considered senior civil servants by the

\footnotetext{
${ }^{61}$ Meyer-Sahling, J.-H. (2012), http://dx.doi.org/10.1787/5k4c42jrmp35-en.

${ }^{62}$ Based on information from DoPA. However, not all these positions may be filled.
} 
countries themselves. These are the core positions that, as a rule, coincide with the scope of the general civil service.

Countries apply two approaches to defining the SCS in practice: they either define particular positions in particular types of institutions in their laws (such as a state secretary of a ministry), in which case both the vertical and horizontal scopes are clear, or they define only generic positions (such as heads of state authorities) in their civil service laws (CSLs), in which case the applicability of SCS status is not determined by the CSL but by the law on state administration or even by specific material laws that regulate whether the head of a public body is part of the civil service or not. Positions outside the executive, such as senior officials in the office of the president, parliament, or constitutional institutions, are not necessarily expected to be subject to the same rules and mechanisms (such as central recruitment) that the government applies due to the need for separation of powers. However, it is not unusual for these positions to be covered by special clauses under the CSL, as it does not always make sense to draft separate legal acts for regulating SCS working conditions in such institutions. Some measures, such as professional development, are not subject to separation of powers and can also be extended to the SCS. 
Box 1. The difference between political and senior civil service positions, and possible anomalies

It is clear that ministers hold political positions in every country, because their mandates are tied to the mandate of the government, usually granted by the parliament. The same applies to deputy ministers and state secretaries, where they exist; however, they may be nominated by the government or a minister instead of the parliament. These positions are excluded from the civil service because their purpose is to set political direction and be accountable for it.

SCS positions are, by definition, regulated by the CSL, which means that certain rights, obligations and restrictions apply. Civil service positions need to be granted technical capacity that survives changes of government, and protection against being misused for partisan purposes or to impair the capacity of future governments to govern ${ }^{63}$. Because of this, the key characteristics of SCS positions should be merit-based recruitment and either indefinite or a clearly defined length of service term independent of the mandate of the sitting government. If these two criteria are not fulfilled, SIGMA would consider the positions to be politically determined due to the potential for politicians to exercise unjustified decision-making authority. From the civil service system perspective, these positions would constitute a design flaw (this will be discussed further in the next section).

\subsubsection{Vertical scope of the senior civil service}

All the Western Balkan administrations examined for this study identify managerial posts in their CSLs and categorise them according to their function and related level of responsibility. To judge the compatibility of SCS vertical scope with the SIGMA definition, two criteria are used: (1) whether all positions are engaged in strategic-level policy making or non-political general management (whether it is called SCS or not); and (2) whether positions that do not carry such a level of responsibility are excluded from this group.

As explained above, some countries define specific positions in their CSLs and others mention generic positions only. Serbia, the FBiH and the RS are the most explicit about what positions in which institutions constitute SCS within the government and other state institutions. At the other extreme are Kosovo and Albania, which define generic categories only (such as general secretaries and equivalent positions). In these

63 OECD (2007), Managing the Political/Administrative Boundary: Study on the Political Involvement in Senior Staffing Decisions and on the Delineation of Responsibilities between Ministers and Senior Civil Servants, report prepared for the 35th Session of the Public Governance Committee, 12-13 April 2007, OECD Publishing, Paris. 
cases, the Government can define these positions and their ranks through secondary legislation. The other administrations fall somewhere in between.

In defining the vertical scope of the SCS, the former Yugoslav Republic of Macedonia is the most restrictive, as its $\mathrm{CSL}^{64}$ mentions Category A managers only (i.e. secretaries) as constituting senior management. Secretaries can, in turn, be found in the ministries (state secretaries) and in agencies (secretaries general), as well as at the municipal level. This is a special case, however, because state secretaries, the most senior-level managers in ministries according to the Law, should be considered politically determined because appointments are not merit-based and terms of office coincide with the government's mandate. Therefore, for the purposes of this paper, the definition of senior civil servant in the former Yugoslav Republic of Macedonia is extended to also encompass heads of sectors, as they fit the definition of being professional civil servants two levels below the minister and have strategic management roles ${ }^{65}$. In Montenegro, the CSL defines senior management positions as secretaries of ministries, directors general within ministries and deputy heads of state authorities. Heads of state authorities are not mentioned among senior management staff even though the CSL includes articles regulating their recruitment and leaves selection and appointment solely at the discretion of the minister. Also, the Law on State Administration states that the CSL should be applied to them, with a few exceptions such as non-applicability of disciplinary measures and performance appraisal. However, as the merit principle is not ensured and important parts of the CSL do not apply to these positions, they can be considered as politically determined $^{66}$. The same applies to heads of government bodies in the former Yugoslav Republic of Macedonia, to whom the CSL does not apply.

In Kosovo and the former Yugoslav Republic of Macedonia, the most senior ministry officials, the general secretaries and state secretaries respectively, are supposed to come from the ranks of the civil service. In BiH at the State level and the RS, and in Serbia and Montenegro, the legal definition of SCS in agencies has the deepest application, to also encompass deputy director positions. Serbia, the $\mathbf{B i H}$ State level and the RS, however, differ from Montenegro in that these administrations also define heads of subordinated bodies as senior civil servants. As a result, Serbia, the BiH State level and the RS have position-wise the most comprehensively delineated SCS in the Western Balkans, but also the most clearly defined (Table 2). That being said, the RS differs from the BiH State level and $\mathbf{F B i H}$ in that application of the concept of civil service is wider there than in the latter two,

64 The former Yugoslav Republic of Macedonia has a Law on Administrative Servants that covers the whole public sector. For the sake of brevity in this report, it is considered equivalent to the CSL and referred to as such.

${ }^{65}$ At the same time, the problem is that secretaries belonging to Category A are civil servants to whom merit-based rules, obligations, limits, and guarantees similar to other civil servants do not apply.

66 The amendments introduced to the Law on Civil Service and State Employees on 28 December 2017 (which come into force on 1 July 2018), will however, give heads of state authorities full civil servant status and introduce similar recruitment procedures to those applied to the Senior Management Staff. 
therefore resulting in a wider SCS in practice even though position-wise the three administrations have the same scope for the SCS (see Annex 2).

Albania is the most notable case among the group because of its Top Management Corps (TMC), created to manage SCS candidates in a resource pool from which the government must draw to fill SCS vacancies.

Table 1. Senior managerial positions as defined in legislation in the Western Balkans

\begin{tabular}{|c|c|}
\hline Albania & $\begin{array}{l}\text { Top-level management: } \\
\text { - Secretary (such as general secretary) } \\
\text { - Director of department (only in Office of the Prime Minister } \\
{[\text { OPM }] \text { ) }} \\
\text { - Director of general directorate } \\
\text { - Equivalent positions elsewhere (e.g. general secretary in } \\
\text { independent institution) }\end{array}$ \\
\hline $\begin{array}{l}\text { BiH State } \\
\text { level }\end{array}$ & $\begin{array}{l}\text { Managerial civil servants: } \\
\text { - Secretary with special assignment } \\
\text { - Secretary of the ministry } \\
\text { - Assistant minister or assistant director } \\
\text { - } \quad \text { Chief inspector }^{67}\end{array}$ \\
\hline FBiH & $\begin{array}{l}\text { Managerial civil servants: } \\
\text { - Senior executive manager (such as secretary of the ministry) } \\
\text { - Assistant head (such as assistant minister) of civil service } \\
\text { authority } \\
\text { - Director of administration within ministry, independent } \\
\text { administration or independent institution } \\
\text { - Chief inspector }\end{array}$ \\
\hline BiH RS & $\begin{array}{l}\text { Managerial civil servants: } \\
\text { - } \text { Assistant minister } \\
\text { - Secretary of ministry } \\
\text { - Director of administrative authority } \\
\text { - Director of administrative organisation } \\
\text { - Their deputies and assistants } \\
\text { - Chief inspector }\end{array}$ \\
\hline
\end{tabular}

67 The chief inspector is head of the inspectorate when the inspectorate is a separate organisational unit in a ministry or other government body. The chief inspector is equivalent to the position of assistant minister (in ministries) or assistant director (in other government bodies). 


\begin{tabular}{|c|c|}
\hline & - Secretary of agency \\
\hline Kosovo & $\begin{array}{l}\text { Senior-level management: } \\
\text { - } \quad \text { Secretary general and equivalent positions } \\
\text { - } \quad \text { Secretary general } \\
\text { - } \quad \text { Director general and equivalent positions elsewhere }\end{array}$ \\
\hline $\begin{array}{l}\text { The former } \\
\text { Yugoslav } \\
\text { Republic of } \\
\text { Macedonia }\end{array}$ & $\begin{array}{l}\text { Category A [senior managers]: } \\
\text { - } \quad \text { Secretary (e.g. state secretary and secretary general }{ }^{68} \\
\text { Category B [heads and state advisers]: } \\
\text { - } \quad \text { Head of sector } \\
\text { - } \quad \text { Assistant to head of sector } \\
\text { - } \quad \text { State adviser } \\
\text { - } \quad \text { Head of department }\end{array}$ \\
\hline Montenegro & $\begin{array}{l}\text { Senior management staff: } \\
\text { - Secretary of ministry } \\
\text { - Director general } \\
\text { - Deputy head of administrative authority } \\
\text { - Deputy head of service } \\
\text { Separate category: } \\
\text { - Head of state authority }\end{array}$ \\
\hline Serbia & $\begin{array}{l}\text { Management positions: } \\
\text { - Secretary of ministry } \\
\text { - Assistant minister } \\
\text { - Director of internal organ within ministry } \\
\text { - Assistant director of internal organ within ministry } \\
\text { - Director, deputy and assistant director of specialised organisation } \\
\text { - Director, deputy director and assistant director of government } \\
\text { service }\end{array}$ \\
\hline
\end{tabular}

${ }^{68}$ General secretaries are appointed in numerous institutions, immediately below the heads of the institutions: the Constitutional Court of the Republic of Macedonia, the Judicial Council of the Republic of Macedonia, the Public Prosecutor's Council of the Republic of Macedonia, the Ombudsman, the Public Attorney of the Republic of Macedonia, the Inspection Council, the State Audit Office, the State Election Committee, the State Committee for Preventing Corruption, the Data Verification Committee, the Committee for Protection of Competition, the Committee for Protection of the Right to Free Access to Public Information, the State Committee for Deciding in Second-Instance Administrative Procedures and Labour Relation Procedures, the Agency for Administration, and the Directorate for Personal Data Protection. 
- Deputy and assistant general secretary of the government

- State attorney and deputy state attorney

Source: Legislation and data collected by SIGMA for this study.

In comparison with SIGMA's definition of senior civil servants, several observations elucidate the relative clarity of the SCS concept in the Western Balkans. In Kosovo and Albania general secretaries and in the former Yugoslav Republic of Macedonia state secretaries are the highest civil servants in ministries ${ }^{69}$. In contrast, in $\mathbf{B i H}$ (the State level, the RS and the FBiH), Montenegro and Serbia, there is no such clear administrative hierarchy, as all senior civil servants in ministries report directly to the minister.

In Kosovo, directors of departments are the second managerial level in ministries and are not considered senior civil servants in the administration's legislation because this group is restricted to a very limited number of positions, and directors of departments are not recognised in the CSL as being at a strategic decision-making level. The situation is similar in the former Yugoslav Republic of Macedonia, where heads of sectors are not considered strategic decision makers either, this is because they are part of the lower category of managers (Category B) rather than secretaries of ministries (Category A). In BiH at all levels and in Serbia, the CSL distinguishes between managerial and executorial positions. The latter do not have strategic management responsibilities, and therefore not considered to be senior civil servants. The heads of units are considered as holding executorial positions.

Heads of subordinated bodies are recognised as senior civil servants in Albania, Kosovo, BiH (all levels) and Serbia. As explained above, in Montenegro, heads of state authorities are also mentioned in the CSL, but their position is politically determined due to relaxed rules in comparison with other SCS positions. In the former Yugoslav Republic of Macedonia these positions are considered political, i.e. no civil service rules apply.

Table 2. Vertical scope of the senior civil service in the Western Balkans, in ministries and in bodies subordinated to ministries by SIGMA definition

\begin{tabular}{|l|l|l|l|l|}
\hline $\begin{array}{l}\text { (Senior) } \\
\text { management } \\
\text { positions as } \\
\text { defined by } \\
\text { SIGMA }\end{array}$ & $\begin{array}{l}\text { Highest SCS } \\
\text { position in } \\
\text { ministry }\end{array}$ & $\begin{array}{l}\text { Second- } \\
\text { highest rank } \\
\text { in ministry }\end{array}$ & $\begin{array}{l}\text { Highest SCS } \\
\text { position in } \\
\text { subordinated } \\
\text { agency }\end{array}$ & $\begin{array}{l}\text { Second-highest } \\
\text { rank in } \\
\text { subordinated } \\
\text { agency }\end{array}$ \\
\hline Albania & $\begin{array}{l}\text { Secretary } \\
\text { general }\end{array}$ & $\begin{array}{l}\text { Director of } \\
\text { general } \\
\text { directorate }\end{array}$ & General director & $\begin{array}{l}\text { No mention of } \\
\text { such a position } \\
\text { in general law }\end{array}$ \\
\hline
\end{tabular}

${ }^{69}$ It is worth noting that in Albania, the General Secretary of the Office of the Prime Minister is officially recognised as the most senior civil servant, above all other General Secretaries. The General Secretary of the Office of the Prime Minister leads and co-ordinates the network of general secretaries' work, e.g. chairs weekly meetings of the General Secretaries. 


\begin{tabular}{|c|c|c|c|c|}
\hline BiH State level & $\begin{array}{l}\text { Secretary of } \\
\text { ministry } \\
\text { Assistant } \\
\text { minister }\end{array}$ & $\begin{array}{l}\text { Head of unit } \\
\text { (not SCS) }\end{array}$ & $\begin{array}{l}\text { Head of authority } \\
\text { (Secretary with a } \\
\text { special } \\
\text { assignment) }\end{array}$ & $\begin{array}{l}\text { Deputy head of } \\
\text { authority }\end{array}$ \\
\hline FBiH & $\begin{array}{l}\text { Secretary of } \\
\text { ministry } \\
\text { Assistant } \\
\text { minister }\end{array}$ & $\begin{array}{l}\text { Head of unit } \\
\text { (not SCS) }\end{array}$ & Head of authority & $\begin{array}{l}\text { Deputy head of } \\
\text { authority }\end{array}$ \\
\hline BiH RS & $\begin{array}{l}\text { Secretary of } \\
\text { ministry } \\
\text { Assistant } \\
\text { minister }\end{array}$ & $\begin{array}{l}\text { Head of unit } \\
\text { (not SCS) }\end{array}$ & Head of authority & $\begin{array}{l}\text { Deputy head of } \\
\text { authority }\end{array}$ \\
\hline Kosovo & $\begin{array}{l}\text { Secretary } \\
\text { general }\end{array}$ & $\begin{array}{l}\text { Head of } \\
\text { department (not } \\
\text { SCS, but } \\
\text { considered so } \\
\text { by SIGMA)* }\end{array}$ & $\begin{array}{l}\text { Director general } \\
\text { and equivalent } \\
\text { positions } \\
\text { elsewhere }\end{array}$ & $\begin{array}{l}\text { No mention of } \\
\text { such a position } \\
\text { in general law }\end{array}$ \\
\hline $\begin{array}{l}\text { The former } \\
\text { Yugoslav } \\
\text { Republic of } \\
\text { Macedonia }\end{array}$ & $\begin{array}{l}\text { State secretary } \\
\text { of ministry } \\
\text { (politically } \\
\text { determined } \\
\text { position)** }\end{array}$ & $\begin{array}{l}\text { Head of sector } \\
\text { (not SCS, but } \\
\text { considered so } \\
\text { by SIGMA)* }\end{array}$ & $\begin{array}{l}\text { Head of authority } \\
\text { (politically } \\
\text { determined } \\
\text { position, not in } \\
\text { CSL)** }\end{array}$ & $\begin{array}{l}\text { No mention of } \\
\text { such a position } \\
\text { in general law }\end{array}$ \\
\hline Montenegro & $\begin{array}{l}\text { Secretary of } \\
\text { ministry } \\
\text { Director general }\end{array}$ & $\begin{array}{l}\text { Head of unit } \\
\text { (not SCS) }\end{array}$ & $\begin{array}{l}\text { Head of state } \\
\text { authority } \\
\text { (politically } \\
\text { determined } \\
\text { position)** }\end{array}$ & $\begin{array}{l}\text { Deputy head of } \\
\text { state authority }\end{array}$ \\
\hline Serbia & $\begin{array}{l}\text { Secretary of } \\
\text { ministry } \\
\text { Assistant } \\
\text { minister }\end{array}$ & $\begin{array}{l}\text { Head of unit } \\
\text { (not SCS) }\end{array}$ & $\begin{array}{l}\text { Director of } \\
\text { internal body } \\
\text { within ministry }\end{array}$ & $\begin{array}{l}\text { Assistant } \\
\text { director of } \\
\text { internal body } \\
\text { within ministry }\end{array}$ \\
\hline
\end{tabular}

Note: * implies that these positions are in the CSL but not defined as SCS, while SIGMA considers that they should be part of it in order to cover both general management function and policy management function at senior level. ** highlights that these positions are politically determined, while SIGMA considers that they should be civil service positions.

Source: Legislation and data collected by SIGMA for this study.

The comparison reveals that each administration generally conceptualises its SCS differently. Interpreting what are classified as SCS positions is straightforward only when they are clearly defined by specific position and type of institution in the CSL, as in Serbia. Otherwise, the distinction depends on: (1) where the line of civil service is drawn; (2) whether the position is obviously a civil service positions or is politically determined. The comparison also demonstrates that Kosovo and the former Yugoslav Republic of Macedonia would benefit from extending their senior management 
category to positions directly below the secretaries of ministries, possibly by elevating the tasks of such positions in the ministry to vest these positions with strategic policy management responsibility and ensure strategic-level continuity in case of a change of secretary. Finally, the former Yugoslav Republic of Macedonia should consider making secretaries and heads of authorities merit-based senior civil service positions ${ }^{70}$.

\subsubsection{Accountability lines and role clarity}

For ministry management, it is important that lines of accountability be clear so that everyone knows the roles and responsibilities of each position. The simplest model would have a single senior civil servant responsible for managing the entire ministry, accountable to the minister. This would make the separation of political and SCS positions very clear, as well as the accountability lines between different political and civil service officials.

There are two clearly distinguishable models in the Western Balkans: (1) monocratic management, such as in Albania and Kosovo (the former Yugoslav Republic of Macedonia could also be considered a special case of this), and (2) functional management, in use elsewhere. For the entire assemblage of senior management ministries (both political and administrative) in all administrations, see Annex 2.

Figure 7. Two ministry governance models in the Western Balkans

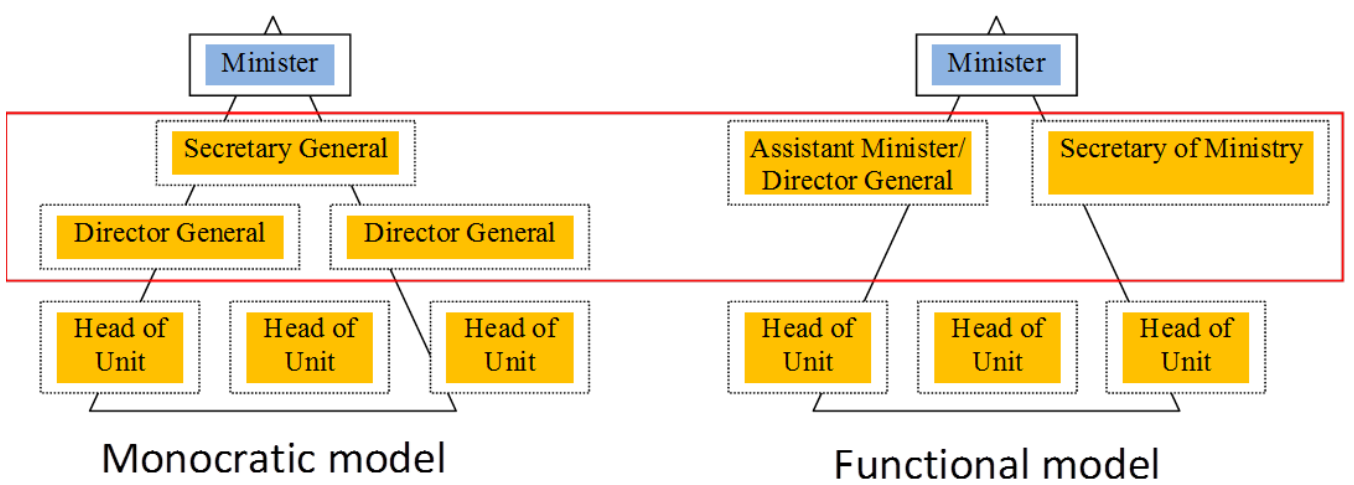

Note: According to SIGMA conceptualisation of SCS, positions in the red box belong to the SCS.

The major distinction is that in the monocratic model, a secretary general is formally responsible for managing the entire ministry, and in the functional model there is a distinction between administrative management (horizontal and focused on resource management) under the secretary of the ministry, and policy management (policy design, analysis and supervision of implementation) under the heads of sectors (or equivalent position of general directors in Montenegro or assistant ministers in Serbia and $\mathbf{B i H}$, all levels) as the most senior policy managers in the ministries. In Montenegro and Serbia, however, one or more state secretaries clearly hold political positions but informally oversee the work of heads of sectors in policy terms, if so decided by the minister, who is also formally the immediate supervisor of the heads of

${ }^{70}$ For example, Montenegro has done so by amending the Law on Civil Service and State Employees on 28 December 2017 (coming into force on 1 July 2018). 
sectors. In the former Yugoslav Republic of Macedonia and at the BiH State level, at least two senior positions in the ministry (e.g. minister and deputy minister, or minister and state secretary) should go to incumbents from different community (and party) backgrounds.

Furthermore, directors of subordinate bodies are quite often considered politically determined positions (at the BiH State level in half of all cases, in the former Yugoslav Republic of Macedonia and in Montenegro) and are often accountable to several positions, such as a minister and the government (the former Yugoslav Republic of Macedonia), or a minister and director general (Montenegro). The overall conclusion is therefore that there is much ambiguity in the management hierarchy in terms of accountability relationships, wherein formal roles are not clear and depend upon the particular assemblage of people at the time. Examining management levels and positions only is rather uninformative due to these intricate relationships among positions.

Table 3. Administrative management models of ministries in the Western Balkans

\begin{tabular}{|l|c|c|}
\hline & $\begin{array}{c}\text { Administrative management of } \\
\text { ministry }\end{array}$ & $\begin{array}{c}\text { Classification of heads of executive } \\
\text { bodies }\end{array}$ \\
\hline Albania & Monocratic & Civil servants \\
\hline BiH State & Functional & $\begin{array}{c}\text { Civil servants and political appointees } \\
(1: 1)\end{array}$ \\
\hline FBiH & Functional & Civil servants \\
\hline BiH RS & Functional & $\begin{array}{c}\text { Formally civil servants but different } \\
\text { rules apply; politically determined }\end{array}$ \\
\hline Kosovo & Monocratic & \begin{tabular}{c} 
Political appointees \\
\hline $\begin{array}{l}\text { The former } \\
\text { Republav } \\
\text { Macedonia }\end{array}$
\end{tabular} \\
\hline Montenegro & Monocratic & $\begin{array}{c}\text { Formally civil servants but different } \\
\text { rules apply; politically determined }\end{array}$ \\
\hline Serbia & Functional & Civil servants \\
\hline
\end{tabular}

Source: Legislation and data collected by SIGMA for this study.

\subsubsection{Horizontal scope of the senior civil service}

Horizontal scope generally refers to the types of institutions in which the CSL is applied. The law on state administration normally distinguishes among the various types of public authorities, based on the level of autonomy from the minister and the government. For bodies within ministries, which is the structure in all the Western Balkan administrations studied, autonomy from the minister is very limited and the scope is relatively clear because civil service rules are universally applied (with 
exceptions such as customs and tax administration and a small number of other cases in some countries). The notable exceptions are at the BiH State level, in which heads of bodies within ministries may or may not be part of the civil service, and the former Yugoslav Republic of Macedonia, where the scope is determined by the specific law through which administrative bodies (including those within ministries) are established, to gauge if they are part of the civil service or not. The scope of the civil service determines also the boundaries of the senior civil service, and as the application of civil service law is inconsistent across similar types of bodies, the SCS is therefore not consistent either.

However, when more autonomous administrative bodies are concerned, it becomes increasingly difficult to judge the applicability of the concept of SCS. In many cases, the administrative bodies are accountable to the minister and therefore should be considered part of the executive - and hence included in the horizontal scope - but these bodies may not apply the CSL, or the governance regime of their top management could be regulated elsewhere. Often the special law by which each autonomous institution is established also defines the rules and regulations on the status of senior management, recruitment procedures, terms of office, etc. Sometimes the ministry or authority in charge of the entire civil service, or the authority managing the SCS specifically, may not have the power to apply the merit principle to such positions, and may not even have information on how many such positions exist; this has a detrimental effect on the coherence and consistency of the SCS concept. Finally, there are independent bodies that are accountable, either directly or through a management board, to the parliament and therefore are not necessarily expected to apply the same rules and mechanisms (for instance, in relation to recruitment) to their senior civil servants as the government does. Some of these bodies may be mentioned in the constitution, meaning their independence is granted at the highest level (Figure $8)^{71}$.

\footnotetext{
${ }^{71}$ For the sake of applying common rules to the same types of bodies, the two bodies indicated in red should be brought under the CSL.
} 
Figure 8. Horizontal application of the senior civil service concept

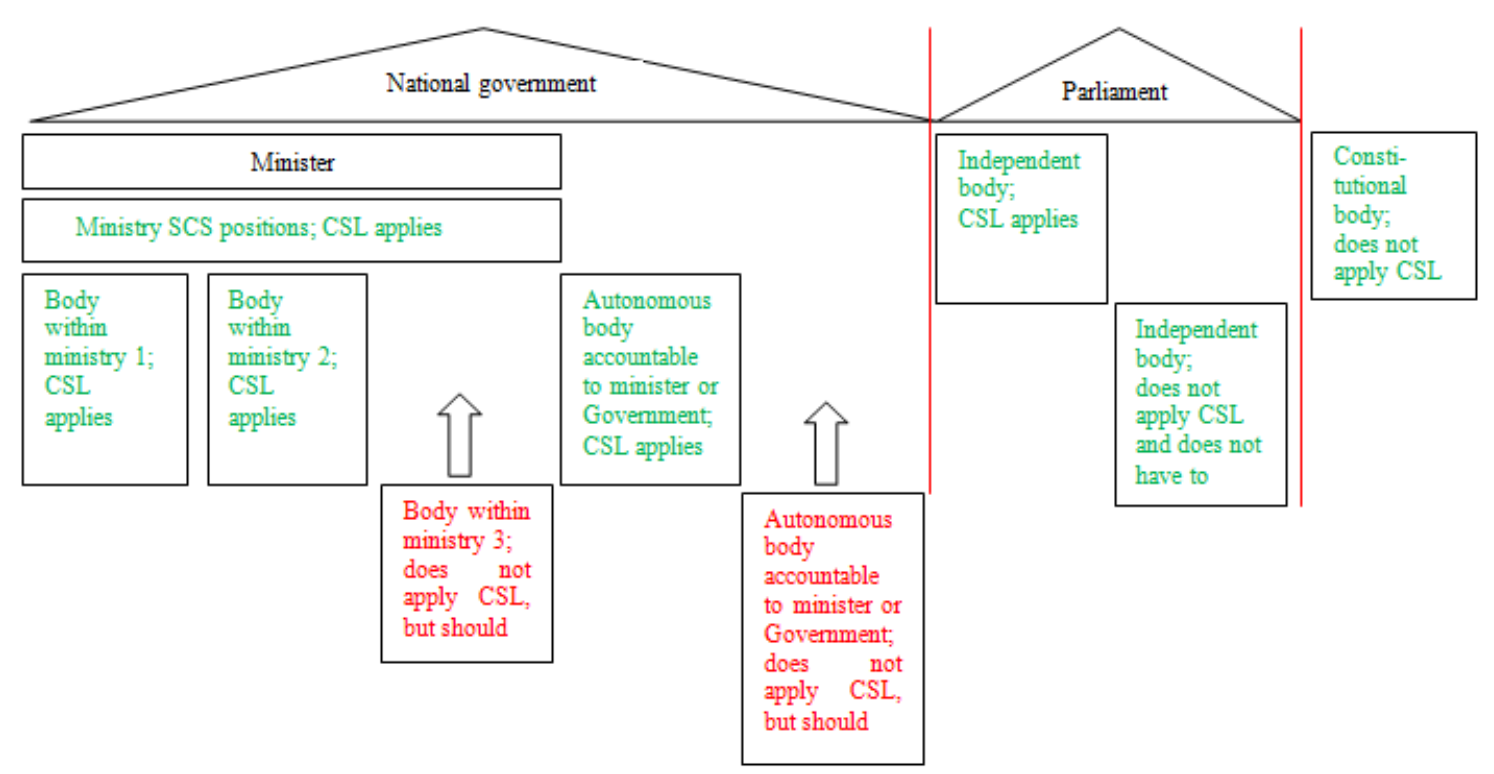

In the FBiH, application of the horizontal concept in the CSL is confusing due to the combining of functional categorisation (type of body and where to be applied, such as administration within ministry, independent administration or institution) with applicability of the CSL (such that the CSL does not state where it is to be applied, but leaves it up to specific legislation). At the BiH State level, regulation of senior management positions includes general secretaries, directors and equivalent positions in executive, independent and regulatory agencies. Heads of government entities are civil service positions to which the CSL applies in principle, but in many cases the terms and conditions are regulated in the special law by which the entity is established. This means they may apply their own recruitment and dismissal criteria, and these positions are not subject to disciplinary sanctions; they are also not involved in training and development provided by the Civil Service Agency, even though their deputies are senior civil servants. The same kind of divide is characteristic of independent bodies some of them are part of the civil service while others are not. Overall, some $50 \%$ of government entities are in such a position. In Albania, there is no central overview in the Department of Public Administration of applying civil service rules in independent bodies, but elsewhere the civil service rules apply to directors of agencies. In Montenegro, the CSL is applied to bodies within ministries, but for bodies not within ministries, the situation is more mixed: some of them apply the CSL and/or a salary law, while the others do not. In Serbia, the horizontal scope of SCS positions (such as administrative authorities within ministries, and certain other specific organisations) are clearly defined in the CSL, but the Law also allows other independent bodies to establish civil service positions, which blurs the line. In Kosovo, 22 of its 32 independent or constitutional bodies, some of them performing executive functions, appoint their senior civil servants based on the laws that established them (special laws), and the other 10 rely on the CSL. These ten agencies are obligated to appoint senior civil servants according to the CSL, as stated in their special law, but the Ministry of Public Administration (MPA) reported that since 2011, only five have conducted procedures in co-operation with it and the Criteria Assessment Commission. 
In the former Yugoslav Republic of Macedonia, the overview of how many positions of each category exist is comprehensive, but there is a variety of independent and special institutions, many of the bodies being directly established by law and accountable to the Assembly. The same applies to many government bodies in Kosovo, which are accountable to the Parliament without proper justification and would be more appropriate under the Government because their function is to execute sector policy and the need for such a high level of autonomy is not obvious ${ }^{72}$.

Systemic inconsistencies aside, the sizes of SCSs in Western Balkan administrations are generally appropriate to keep the groups manageable while providing opportunities for internal mobility (Table 4). However, if more articulate government policy objectives for the SCS require the central management authority to apply active policy measures (e.g. training and development), the first area needing improvement is central data collection on the number and breakdown of senior civil servants, and on what rules apply in which institution. It would be essential to first know to whom the CSL applies, and for those not covered, whether the merit principle is still ensured.

Table 4. Number of senior civil service positions

\begin{tabular}{|l|l|l|}
\hline Albania & 115 & No breakdown available \\
\hline BiH State & 271 & $\begin{array}{l}52 \text { special assignment secretaries (i.e. directors of } \\
\text { agencies, heads of other administrative bodies), 40 } \\
\text { secretaries, 174 assistant ministers and assistant } \\
\text { directors, 5 inspectors general. }\end{array}$ \\
\hline FBiH & 167 & $\begin{array}{l}21 \text { heads of administrative body, 20 secretaries, 8 heads } \\
\text { of administrative bodies within ministries, 107 assistant } \\
\text { heads (ministries and all other institutions), 11 chief } \\
\text { federal inspectors. }\end{array}$ \\
\hline BiH RS & 162 & $\begin{array}{l}15 \text { secretaries of the ministry, 51 assistant ministers, 13 } \\
\text { chief republic inspectors, 1 secretary of the CSA and } \\
\text { assistant directors, 38 heads of republic administrative } \\
\text { body, 8 deputy heads of republic administrative body, 36 } \\
\text { assistant heads of republic administrative body. }\end{array}$ \\
\hline Kosovo & 101 & $\begin{array}{l}76 \text { senior civil servants from ministries and executive } \\
\text { agencies, 25 from independent institutions. }\end{array}$ \\
\hline $\begin{array}{l}\text { The former } \\
\text { Yugoslav } \\
\text { Republic of } \\
\text { Macedonia }\end{array}$ & 273 & $\begin{array}{l}14 \text { state secretaries of ministries, Secretary General of } \\
\text { the Government, Secretary of the Secretariat for } \\
\text { Legislation, 29 heads of bodies within ministries, 177 } \\
\text { heads of sectors in ministries, 51 heads of sectors in } \\
\text { bodies within ministries }\end{array}$ \\
\hline
\end{tabular}

\footnotetext{
${ }^{72}$ For a comprehensive Review of Institutions and Agencies of the Assembly and Central Bodies of the Government see: https://map.rks-gov.net/getattachment/1d5a601b-3d46-4028-a5adb7ba07d9b109/Review-of-institutions-and-agencies-of-the-assembl.aspx.
} 


\begin{tabular}{|l|l|l|}
\hline Montenegro & 157 & $\begin{array}{l}14 \text { secretaries of ministries, 72 directors general, 19 } \\
\text { heads of bodies within ministries, 37 deputy heads of } \\
\text { bodies within ministries, and 15 heads of independent } \\
\text { authorities }\end{array}$ \\
\hline Serbia & 350 & $\begin{array}{l}15 \text { secretaries, 112 assistant ministers, 29 directors of } \\
\text { authorities within ministries and 53 of their deputies, and } \\
17 \text { directors of special organisations and 56 of their } \\
\text { deputies and assistants, 14 directors and 49 deputy and } \\
\text { assistant directors from the Government Service; } 1 \\
\text { deputy general secretary and 4 assistant general } \\
\text { secretaries from the Government General Secretariat }\end{array}$ \\
\hline
\end{tabular}

Note: This table uses national definitions of the positions as given in Table 1, except for the former Yugoslav Republic of Macedonia, where category B includes positions which are not senior civil servants. Thus, for comparability purposes, Table 4 includes only heads of sectors from Category B, which SIGMA considers SCS positions. Due to data quality and comparability issues, these numbers are indicative only. The data for Albania is shown without independent institutions, for which data is not centrally available.

Source: based on data provided by the administration (BiH all levels, Kosovo, and the former Yugoslav Republic of Macedonia) at the beginning of 2018 or collected by SIGMA (Montenegro and Serbia) in mid-2017.

\subsubsection{Responsibilities and roles of the senior civil service}

In the Western Balkans, the responsibilities of senior civil servants are formulated rather vaguely. Essentially, the model is extremely concentrated to give ministers the authority to make most resource-related decisions. During the SIGMA 2017 assessments, 34 ministries across the Western Balkans were asked to report whether decision-making related to the 7 categories presented in Table 5 was delegated by the minister to the administration. It was determined that delegation is not alien to any of these areas, but the least-delegated area of decision making is clearly recruitment. Variation among ministries is also significant, even within one administration, from no delegation to complete delegation (i.e. in all seven areas).

Overall, this ad-hoc type of delegation strips senior civil servants of clear role definitions, and hence the basis to be precise about job requirements and end-related professional expectations. Moreover, these limitations and instability may make senior management positions less attractive for capable candidates.

Table 5. Delegation of decision making from minister or secretary to a lower level in administrations across the Western Balkans (number of instances in 34 ministries questioned)

\begin{tabular}{|l|c|}
\hline $\begin{array}{l}\text { Procurement of low-value purchases (under EUR 5 000) signed below the } \\
\text { level of minister }\end{array}$ & 14 \\
\hline $\begin{array}{l}\text { Recruitment decisions and employment contracts of senior advisors and } \\
\text { similar positions signed below the level of minister }\end{array}$ & 13 \\
\hline Payments of ministry staff salaries signed below the level of minister & 16 \\
\hline Replies to public information requests signed below the level of minister & \\
\hline
\end{tabular}




\begin{tabular}{|l|c|}
\hline $\begin{array}{l}\text { Annual leave requests formally approved below the level of permanent } \\
\text { secretary or equivalent }\end{array}$ & 9 \\
\hline $\begin{array}{l}\text { Business trips of staff members formally approved below the level of } \\
\text { permanent secretary or equivalent }\end{array}$ & 4 \\
\hline $\begin{array}{l}\text { Training participation for staff members approved below the level of } \\
\text { permanent secretary or equivalent }\end{array}$ & 7 \\
\hline
\end{tabular}

Source: Data collected for the SIGMA 2017 assessments.

\subsubsection{Length of terms of office}

As senior civil servants are supposed to guarantee continuity over the terms of governments and be protected from politically motivated replacement, it is important that their terms of office do not generally coincide with those of the government. If the length of a term does nominally coincide with that of the government, it may not be a problem, as senior civil servants are hired at different times and do not therefore terminate their terms of office at the same time. If, however, the terms of senior civil servants are directly linked to the mandate of the government (i.e. they come and go with the minister), this clearly associates them with the ruling party and it would be difficult for a different incoming party minister to fully trust them. In addition, even if terms do not coincide with government mandates, it must be ensured that they are not too short, as this would make the SCS more vulnerable to undue political influence in hopes of being re-nominated.

The nominal parliamentary electoral cycle in all the administrations is four years. The former Yugoslav Republic of Macedonia is the only administration where secretaries' terms of office are terminated upon expiration of the government's mandate. Elsewhere, even if there is no formal link between the mandates, incoming governments or ministers tend to replace many senior civil servants.

Table 6. Lengths of terms of office

\begin{tabular}{|l|l|}
\hline Albania & $\begin{array}{l}\text { Indefinite in principle, but secretaries general can be dismissed after } \\
\text { changes of government }\end{array}$ \\
\hline BiH State & $\begin{array}{l}\text { Indefinite for ministry secretaries and for assistant ministers, fixed for } \\
\text { heads of agencies and secretaries under special assignment (up to 5 } \\
\text { years), renewable once (subject to open competition) }\end{array}$ \\
\hline FBiH & Indefinite \\
\hline BiH RS & $\begin{array}{l}5 \text { years, renewable without limits (not automatically renewable, open } \\
\text { competition required) }\end{array}$ \\
\hline Kosovo & 3 years, renewable without limits \\
\hline $\begin{array}{l}\text { The former } \\
\text { Yugoslav } \\
\text { Republic of } \\
\text { Macedonia }\end{array}$ & \begin{tabular}{l} 
For years, leaving with the minister \\
\hline
\end{tabular}
\end{tabular}




\begin{tabular}{|l|l|}
\hline Montenegro & 5 years, not automatically renewable (open competition required) \\
\hline Serbia & 5 years, renewable without limits \\
\hline
\end{tabular}

Source: Legislation and data collected by SIGMA for this study.

The most common fixed-term appointment of senior civil servants is for five years; this is also the most common practice in EU member countries ${ }^{73}$. Quite often, senior civil servants can leave their position and return to another in the civil service: this is the case for ministry secretaries in the former Yugoslav Republic of Macedonia, incumbents of positions who have fixed-term appointments at the BiH State level and secretaries general in Kosovo, as well as in the BiH RS and Serbia senior management systems in general. In Serbia, senior civil servants do not lose civil servant status automatically due to expiration of their mandate, organisational changes or even in case of resignation. In such cases, they may be reassigned to another appropriate position (an executive civil service position) within the same state authority, but if a position does not exist, the senior civil servant becomes "unassigned" with the same rights and obligations as other unassigned civil servants. Unassigned status ends after only two months, however.

A somewhat similar mechanism applies in Albania, where TMC members have the right to stay in the pool upon release from office. Even though the term of office in Albania is not fixed in principle, in practice the replacements which followed the change of Government in 2017 demonstrated that secretaries general may not have job security. Such practices can result in wide reshuffling of the SCS, and may endanger continuity and institutional memory.

Under the position-based system in Montenegro, senior management terms of office are not automatically renewed, but rather an open competition must be launched each time.

In contrast, at the BiH State level (except secretaries with special assignment) and in the $\mathbf{F B i H}$, senior civil servants in ministries have indefinite terms of office both by law and in practice. Even though this is positive for stability and continuity, it may prevent changes (for example, to bring fresh skills and thinking into the office) from being implemented in a legally legitimate way.

\subsubsection{Requirement of political neutrality}

There are no specific requirements in legislation obligating political neutrality of the SCS, but general provisions do apply. In many administrations, the CSL requires that civil servants fulfil their mandates in a politically neutral manner (Albania, BiH at all levels, Kosovo, Montenegro, Serbia). In Kosovo, the ethos of the CSL is to set up a politically neutral and impartial civil service. The CSL also clearly states that civil servants may not occupy managerial positions in political parties and may not be politically active, but can belong to a political party or establish one; it does, however, permit civil servants to temporarily occupy political positions during the period in which their civil servant status is suspended. The CSL also regulates civil servants' preparation for elections. In Montenegro, the Law on Civil Service and State

\footnotetext{
${ }^{73}$ Kuperus and Rode, (2016), p. 29.
} 
Employees states that a civil servant and a state employee shall perform their tasks in a politically neutral and impartial manner, in accordance with public interest. In Serbia, civil servants are expected to perform their duties in accordance with the Constitution, laws and other regulations, according to the rules of professionalism and in an impartial and politically neutral way. Civil servants are not allowed to express and represent their own political beliefs in performing their tasks. Likewise, in the RS, civil servants may not express or represent political affiliations when performing their tasks, and more specifically they may be neither founders nor members of bodies of political parties, nor members of municipal councils or the Assembly. At the BiH State level and in the $\mathbf{F B i H}$, there are also restrictions in legislation preventing civil servants being members of the boards or bodies within political parties.

However, Albania goes a step further than any other Western Balkan administration. It is an interesting case because since 2014 senior civil servants (but not the lower ranks) have been prohibited from belonging to a political party, even though some countries would consider this a violation of a person's constitutional rights. Before 2014, the restriction merely prohibited belonging to management bodies of parties; no other country has set such restrictions.

The CSL of the former Yugoslav Republic of Macedonian states that heads of agencies may not be members of the managing organs of political parties. Disciplinary measures may be taken in the case of a civil servant "expressing and advocating political beliefs when performing the work assignments, participating in election activities and other public events of similar nature during working hours, putting in question his or her status of administrative servant with the conduct of party activities [or] wearing or displaying party symbols in the work premises".

Practice in the Western Balkans differs substantially from the law, according to a series of interviews conducted to investigate actual practices concerning the SCS. Many senior civil servants are clearly affiliated with the ruling party and quite often are party members. None of the administrations publish party membership lists, but SIGMA interviews revealed that even without official lists it is usually publicly known which civil servant supports which party. Also, it is common for SCS positions to be the subject of negotiations between the parties that form the government. This is, of course, detrimental to the political neutrality expected by law, and in practice results in excessive replacements with changes of the ruling party or parties.

\subsubsection{Restrictions on the senior civil service}

Restrictions on civil servants participating in activities beyond their regular work, such as additional work or exercising ownership rights in companies guarantee their impartiality in performing their tasks and allow them to concentrate on their main body of work without distractions. All of the analysed Western Balkan administrations have set general restrictions on activities allowed for civil servants, and the conditions thereof, beyond their regular work. These rules are not specific to senior civil servants but apply to the entire civil service, except some that have been designed to specifically disclose the interests of certain senior officials (not restricted to senior civil servants) beyond their work. Usually, it is the CSL that sets such restrictions, and/or the law on the prevention of corruption.

The most common restriction is that senior civil servants may not serve in management bodies of for-profit or non-profit organisations. This is meant to avoid conflicts of interest as well as distractions from their main work, although there may 
be some exceptions to the rule, such as serving on management bodies of humanitarian or sports organisations. Areas of extra work may be clearly delineated - restricted, for example, to educational and scientific work. In any case, the general rule is that for any additional work, permission in writing must be sought prior to accepting the extra work from the employer. In the former Yugoslav Republic of Macedonia, the labour code sets restrictions on additional employment; prior agreement from the employer is required, and extra work cannot exceed ten hours per week. Finally, Kosovo and Montenegro also set restrictions on post-employment work for a certain period, such as one or two years upon termination of a mandate, to prevent senior civil servants from using information acquired on certain subjects and companies to their advantage.

\subsubsection{Main findings}

1. The SCS as a distinct set of managerial positions has been defined in all of the administrations through listing the positions to which distinct rules apply (separate from the rest of the civil service) in their CSLs, but the definitions vary considerably. In Albania, the notion of a specific senior management corps is unique in the Western Balkans, as no other administration recognises the SCS as a distinct entity. Other administrations consider that differentiating this category from the rest of the civil service is necessary mostly for recruitment purposes (involving political appointments) and for fixing terms of office for such positions.

2. In terms of combined vertical and horizontal scope, this group varies significantly: from rather restricted (Kosovo) to broad and deep (Serbia, the $\mathrm{BiH}$ State and the RS). Because most of the administrations define senior management positions generically in their CSLs, the scope can be clarified only by studying to which bodies the CSLs apply. In most cases, application is effectively restricted to bodies under the government, and even if the scope is wider (i.e. the CSL applies to independent bodies), central management bodies have no overview or control over them. This means that there is a lack of consistency in applying the rules to similar types of government bodies, which undermines the overall coherence of the senior managers' group, hindering solidification of a common identity and ethos of serving the public good.

3. Accountability lines between political and SCS positions are clear in administrations with a monocratic ministerial management model, but not elsewhere. Only in Albania, Kosovo and the former Yugoslav Republic of Macedonia is the administrative management model of ministries relatively monocratic. The other administrations have multiple accountability lines between political and SCS positions, which complicates accountability regimes and makes effective management of ministries and their subordinate agencies more complex. Furthermore, accountability lines of the heads of the subordinate bodies are frequently dual, reporting to the minister and to the Government.

4. In Western Balkan administrations, ministers have been given the authority to make most resource-related decisions (including in relation to HRM, such as hiring) within the ministry. This limits the managerial role of senior civil servants and diminishes their ability to lead organisations; moreover, it may make senior management positions less desirable for capable candidates who are not interested in management positions of such limited and unstable scope. 
5. Heads of government bodies either subordinated to the ministry or having greater autonomy vary considerably in whether they are politically determined or civil service positions. In the RS, Serbia and Albania it is clear that all the heads of government bodies are civil servants, whereas in the former Yugoslav Republic of Macedonia and Montenegro they are politically determined. This conflicts with their technical-managerial functions in policy implementation (apart from independent institutions that have different functions, such as market regulators). In $\mathrm{BiH}$ at the State level and the $\mathrm{FBiH}$, whether positions are considered part of the civil service or are politically determined varies from one institution to another without clear rules as to why the CSL is applied or not. Overall, all these positions should fall under the SCS regime and the merit principle should be applied to decisions on working conditions, especially recruitment and dismissal.

6. In most cases terms are fixed (three to five years), but renewal systems vary. Only in the former Yugoslav Republic of Macedonia do service terms coincide with the electoral cycle, resulting in institutionalised turnovers of ministry secretaries after elections.

7. Although in most administrations the legal framework clearly stipulates political neutrality, empirical evidence shows that it is not being followed in practice.

8. Requirements and restrictions on additional activities are generally in place to guarantee impartiality.

\subsection{Recruitment and selection for senior civil service positions}

The characteristics of recruitment processes depend on whether the overall system is more career- or position-based, which significantly affects the level of centralisation and openness to external candidates. Western Balkan administrations vary in both of these characteristics. To mark the general approach taken in the recruitment process, these two features are briefly described below. It is followed by a comparative overview of recruitment processes across the Western Balkans (Section 2.2.1.), and discussion of recruitment practices across main phases of recruitment (Sections 2.2.2., 2.2.3 and 2.2.4.). These are: (1) application, including setting eligibility criteria, attracting candidates, announcing vacancies, sending applications and verifying documents; (2) assessment including selection committees and testing methods; and (3) appointments, including appeals and use of acting positions.

Regarding the level of centralisation, most Western Balkan administrations organise recruitment in a hybrid manner, with the central management body supervising or directly involved, and representatives of the body with the vacancy significantly involved in some administrations. Control of the central recruitment bodies over final selections is sometimes questionable, as their role can be only administrative, i.e. they do not lead the recruitment process, and their representatives can be outvoted. Recruitment is centralised at the highest level in Albania, which uses pool recruitment for senior positions. This is quite an unusual solution, as pool recruitment is more frequently used for entry-level hiring to civil service, and all the other administrations recruit senior civil servants for individual positions. Recruitment is relatively decentralised in $\mathrm{BiH}$, with SCS recruiting processes carried out separately according to different rules at the State level, the $\mathbf{R S}$ and the FBiH. 
Regarding the openness of the recruitment, some of the administrations analysed give preference to internal candidates and accept applications from external ones only if internal competition fails (Serbia, the State level of $\mathrm{BiH}$, the $\mathrm{FBiH}$ and Kosovo); others make it clear from the beginning that external candidates may apply in parallel with internal ones (Montenegro and the RS). In Albania, selection is open to internal candidates only, but exceptions are possible. In the administrations that allow for both internal and external recruitment, however, the selection procedures are the same, which is questionable, as one procedure cannot successfully test both internal candidates - who already have experience and knowledge about the functioning of the public sector and a proven track record - and candidates from outside the public service, possibly without any prior public sector experience. This also usually overcomplicates the procedure for internal candidates, who must submit the same documents required of external candidates even though the administration should have their track record and capacities on file. The former Yugoslav Republic of Macedonia does not organise competitions for A-category civil servants (one level below the minister), as they are discretionally appointed from among B-category civil servants. In most EU countries recruitment for senior positions is open to external candidates $^{74}$.

\subsubsection{Comparative overview of the recruitment process across the Western Balkans}

The main features of Western Balkan recruitment processes, divided into application, assessment and appointment, are summarised in Table 7. As the recruitment process often includes many specific procedures and requirements, a more detailed overview of each administration's recruitment process (available in Annex 3) was prepared to facilitate the comparative analysis.

Table 7. Comparison of senior civil service recruitment processes in the Western Balkans

\begin{tabular}{|l|l|l|l|}
\hline Administration & Application & Assessment & Appointment \\
\hline Albania & $\begin{array}{l}\text { - non-discriminatory } \\
\text { eligibility criteria are } \\
\text { used }\end{array}$ & $\begin{array}{l}\text { - centrally organised by a } \\
\text { permanent body and } \\
\text { independent from the body } \\
\text { that has the vacancy } \\
\text { - some candidate- } \\
\text { friendly solutions have } \\
\text { been instituted (e.g. } \\
\text { filing copies of } \\
\text { documents) }\end{array}$ & $\begin{array}{l}\text { - pool recruitments are } \\
\text { applied, as a rule } \\
\text { discretion on choice } \\
\text { from the pool of selected } \\
\text { candidates }\end{array}$ \\
$\begin{array}{l}\text { internal candidates only, } \\
\text { with some exceptions }\end{array}$ & $\begin{array}{l}\text { - compulsory training } \\
\text { stage not yet applied } \\
\text { allowed by legislation }\end{array}$ \\
& $\begin{array}{l}\text { - a mix of assessment } \\
\text { - both written and oral } \\
\text { parts of assessment } \\
\text { obligatory }\end{array}$ & $\begin{array}{l}\text { - appeal rights are } \\
\text { ensured }\end{array}$ \\
\end{tabular}

${ }^{74}$ Kuperus and Rode, 2016, p. 33. 


\begin{tabular}{|c|c|c|c|}
\hline & & $\begin{array}{l}\text { - first steps towards } \\
\text { development of } \\
\text { competency framework } \\
\text { have been taken }\end{array}$ & \\
\hline BiH & $\begin{array}{l}\text { - internal competitions } \\
\text { have priority at the State } \\
\text { level and in the FBiH; } \\
\text { open recruitment as a } \\
\text { rule in the RS } \\
\text { - non-discriminatory } \\
\text { eligibility criteria are } \\
\text { ensured } \\
\text { - user-friendly web } \\
\text { portals post } \\
\text { announcements } \\
\text { - deadline for submitting } \\
\text { documents is at least ten } \\
\text { days (some exceptions } \\
\text { possible) } \\
\text { - in the RS, copies of } \\
\text { documents are sufficient } \\
\text { for the first stage of the } \\
\text { procedure; in the FBiH, } \\
\text { in the early stages no } \\
\text { documents have to be } \\
\text { submitted; at the State } \\
\text { level, authorised copies } \\
\text { are required }\end{array}$ & $\begin{array}{l}\text { - selection committees are } \\
\text { ad hoc, and include } \\
\text { representatives of the } \\
\text { bodies in which the } \\
\text { vacancy exists } \\
\text { - in the FBiH and the RS, } \\
\text { representatives of the } \\
\text { ministry with the vacancy } \\
\text { are in the majority on the } \\
\text { selection committee } \\
\text { - at the State level and in } \\
\text { the FBiH, both written and } \\
\text { oral tests are required, } \\
\text { which is not the case in the } \\
\text { RS, where only oral } \\
\text { examination is obligatory } \\
\text { (apart from certification } \\
\text { prior to the selection } \\
\text { process) } \\
\text { - pre-examination can be } \\
\text { costly, as in the RS } \\
\text { - the State level began } \\
\text { using a competency } \\
\text { framework recently } \\
\text { - ethnic representation is } \\
\text { taken into account in the } \\
\text { selection process }\end{array}$ & $\begin{array}{l}\text { - acting senior civil } \\
\text { servants are not } \\
\text { regulated by legislation, } \\
\text { allowing for misuse in } \\
\text { the FBiH } \\
\text { - in the FBiH and at the } \\
\text { State level, the list of } \\
\text { candidates that can be } \\
\text { appointed to senior } \\
\text { positions is not limited, } \\
\text { but in the RS the best } \\
\text { candidate should be } \\
\text { appointed } \\
\text { - appeal rights are } \\
\text { ensured }\end{array}$ \\
\hline $\begin{array}{l}\text { The former } \\
\text { Yugoslav } \\
\text { Republic of } \\
\text { Macedonia } \\
\text { For the highest } \\
\text { senior civil } \\
\text { service } \\
\text { positions (A- } \\
\text { category), } \\
\text { appointments } \\
\text { are } \\
\text { discretionary by } \\
\text { the relevant } \\
\text { minister } \\
\text { without any } \\
\text { merit-based }\end{array}$ & $\begin{array}{l}\text { For category B: } \\
\text { - recruitment process } \\
\text { open to external } \\
\text { candidates } \\
\text { - non-discriminatory } \\
\text { eligibility criteria are } \\
\text { used, but some of them } \\
\text { are excessive, for } \\
\text { example those related to } \\
\text { language and IT } \\
\text { certificates } \\
\text { - some privileges for } \\
\text { persons with special } \\
\text { needs are applied } \\
\text { - application deadlines } \\
\text { are too short }\end{array}$ & $\begin{array}{l}\text { For category B: } \\
\text { - ad hoc recruitment } \\
\text { committees, comprising } \\
50 \% \text { representatives of the } \\
\text { body with vacancy } \\
\text { - wide range of assessment } \\
\text { techniques used, including } \\
\text { personality test, special } \\
\text { arrangements to prevent } \\
\text { cheating during written } \\
\text { exam } \\
\text { - both written and oral } \\
\text { parts of assessment are } \\
\text { obligatory } \\
\text { - the selection process } \\
\text { does not differ much for }\end{array}$ & $\begin{array}{l}\text { For category B: } \\
\text { - regulations on } \\
\text { appointments do not } \\
\text { allow political discretion } \\
\text { - highest-ranked } \\
\text { candidates are appointed } \\
\text { - positive discrimination } \\
\text { for under-represented } \\
\text { communities } \\
\text { - legislation sets limits } \\
\text { on acting positions } \\
\text { - appeal rights are } \\
\text { ensured }\end{array}$ \\
\hline
\end{tabular}




\begin{tabular}{|c|c|c|c|}
\hline $\begin{array}{l}\text { competition or } \\
\text { selection } \\
\text { procedure. }\end{array}$ & $\begin{array}{l}\text {-vacancy announcements } \\
\text { are wide-reaching }\end{array}$ & non-managerial positions & \\
\hline Montenegro & $\begin{array}{l}\text { - recruitment possible } \\
\text { through open } \\
\text { competition only } \\
\text { - legal provisions provide } \\
\text { non-discriminatory } \\
\text { eligibility criteria and } \\
\text { application process } \\
\text { - announcements widely } \\
\text { advertised }\end{array}$ & $\begin{array}{l}\text { - centrally organised } \\
\text { process } \\
\text { - ad hoc selection } \\
\text { committees with } \\
\text { representatives from the } \\
\text { body with the vacancy }{ }^{75} \\
\text { - politicians can be } \\
\text { members of selection } \\
\text { committees } \\
\text { - written testing is not } \\
\text { obligatory }\end{array}$ & $\begin{array}{l}\text { - minister can choose } \\
\text { from the five highest- } \\
\text { ranked candidates }{ }^{77} \\
\text { - appeal rights are } \\
\text { ensured } \\
\text { - legislative limits for } \\
\text { acting positions exist }\end{array}$ \\
\hline Kosovo & $\begin{array}{l}\text { - internal candidates have } \\
\text { priority } \\
\text { - non-discriminatory } \\
\text { eligibility criteria are } \\
\text { ensured } \\
\text { - deadlines for } \\
\text { submission of documents } \\
\text { are not specified by } \\
\text { legislation } \\
\text { - submitted documents } \\
\text { need to be notary- } \\
\text { approved }\end{array}$ & $\begin{array}{l}\text { - ad hoc selection } \\
\text { committees } \\
\text { - selection methods left to } \\
\text { discretion of selection } \\
\text { committees } \\
\text { - no obligation for written } \\
\text { test }\end{array}$ & $\begin{array}{l}\text { - preferences for } \\
\text { minorities are ensured } \\
\text { - one of the three } \\
\text { highest-ranked } \\
\text { candidates should be } \\
\text { appointed } \\
\text { - legislative limits for } \\
\text { acting positions exist } \\
\text { - appeal rights are } \\
\text { ensured }\end{array}$ \\
\hline Serbia & $\begin{array}{l}\text { - internal recruitment has } \\
\text { a priority } \\
\text { - filing time for } \\
\text { applications could be as } \\
\text { short as eight days } \\
\text { - clear, non- } \\
\text { discriminatory criteria } \\
\text { have been established } \\
\text { - wide reach of } \\
\text { announcements, user- }\end{array}$ & $\begin{array}{l}\text { - centralised recruitment, } \\
\text { with representatives of the } \\
\text { body with the vacancy on } \\
\text { the selection committee } \\
\text { - no obligation to conduct } \\
\text { written testing } \\
\text { - wide range of assessment } \\
\text { techniques, including } \\
\text { standardised tests } \\
\text { conducted by }\end{array}$ & $\begin{array}{l}\text { - limitations on terms of } \\
\text { acting senior civil } \\
\text { servants exist but are not } \\
\text { enforced } \\
\text { - possibility to not } \\
\text { appoint any of the } \\
\text { proposed candidates } \\
\text { - appeal rights are } \\
\text { ensured }\end{array}$ \\
\hline
\end{tabular}

${ }^{75}$ According to the recently adopted CSL, this also applies to the ministry in case of selection for the position of Head of Administration Authority.

${ }^{76}$ Written testing and structured interviews are obligatory, according to the recently adopted CSL (with some exceptions possible as regards the heads of administration authorities).

77 According to the recently adopted CSL, minister will be able to choose from three highestranked candidates. 


\begin{tabular}{|l|l|l|l|}
\hline & $\begin{array}{l}\text { friendly web page } \\
\text { - more than five eligible } \\
\text { candidates per position }\end{array}$ & psychologists & \\
\hline
\end{tabular}

Source: Legislation and data collected by SIGMA for this study.

Albania's system of announcements and selection is well regulated. Appointing the very top managers from a pool of pre-selected candidates is an unusual solution in the region. The main shortcoming is that, because SCS positions are so particular, the National Selection Committee (NSC) cannot tailor the recruitment process to its specific needs, as candidates do not apply for specific positions. Another shortcoming is non-implementation of the main procedure for accessing the SCS - passing a training programme at the Albanian School of Public Administration (ASPA) as a prerequisite for being appointed to the pool of candidates.

Application of the merit principle in $\mathbf{B i H}$ is uneven at the State level and in the Entities. The process of applying for vacancies is user-friendly, except at the State level, where authorised copies of documents are required. The selection process is organised differently across the levels; at the State level a competency framework recently came into use (in the $\mathbf{F B i H}$ it has been developed but not yet implemented), and the process is quite formalised. During the appointment phase, the level of discretion is usually too high: in the $\mathrm{FBiH}$ and at the State level, any of the candidates proposed by a selection committee may be appointed. Moreover, in the FBiH there are no legal restrictions on appointing acting senior civil servants.

In the former Yugoslav Republic of Macedonia, appointment of most senior civil servants (category A) is discretional and no merit is ensured, although a minimum level of professionalism is guaranteed because recruitment is from among existing middle management-level civil servants. These middle-management civil servants (two levels below the minister) undergo the same recruitment process as other civil servants. However, this raises questions about suitability of the recruitment procedures for senior managerial positions.

In Montenegro, selection practices do not ensure sufficient verification of candidates, as selection is based on structured interviews only, with no standards set for conducting those interviews ${ }^{78}$. Significant scope for subjective appointment of candidates, coupled with a very low average number of eligible candidates $\left(1.4^{79}\right)$, means that almost anyone meeting the formal criteria could be appointed ${ }^{80}$. Most respondents of qualitative interviews pointed out the high level of politicisation in the recruitment process.

${ }^{78}$ However, this shortcoming is addressed in the recently adopted amendments to the Law on Civil Service and State Employees which makes, as a rule, written testing and structured interviews obligatory.

${ }^{79}$ OECD (2017), SIGMA, Monitoring Report: Montenegro, OECD, Paris, http://www.sigmaweb.org/publications/Monitoring-Report-2017-Montenegro.pdf.

${ }^{80}$ The amendments adopted to the Law on Civil Service and State Employees on 28 December 2017, limit the final selection to the three highest-ranked candidates in Montenegro. 
In Kosovo, application procedures are over-formalised and costly, and the selection process is not sufficiently regulated and does not ensure merit. The legislation ensures that the minister can only appoint one of the three highest-ranked candidates. However, there are examples of appointments to senior civil service positions with a violation of the legal provisions ${ }^{81}$. The share of acting positions is at a satisfactory level.

In Serbia, the application and selection process is rather formalistic, although it has many good features such as a user-friendly web page with announcements, a large variety of selection techniques available, and a competency framework drafted but not yet in use. The primary problem is the appointment phase, in which the lack of obligation to appoint selected candidates and the misuse of acting positions bring the entire process into question and call for urgent improvement. The greatest barrier to reform in Serbia is the non-acceptance of merit-based procedures by politicians, who try to appoint many 'acting' senior civil servants without any competitive procedures $^{82}$.

\subsubsection{Application phase}

The application process is not discriminatory and meets the legal preconditions for merit-based selection in most Western Balkan administrations. However, the number of eligible candidates per position is usually low, indicating low competitiveness and attractiveness of the SCS (but this may also indicate a lack of trust in recruitment procedures). Data collected during the SIGMA 2017 assessments shows that in Serbia there were 5.2 eligible candidates per vacancy, but only 2.1 in Albania and 1.4 in Montenegro $^{83}$. Data is missing for the rest of the administrations.

Low competitiveness may result from the application process in some Western Balkan administrations being too formalistic and burdensome. Sometimes deadlines for filling in the documents are too short, and the cost of preparing the documents is significant.

It may also signal that wider advertising of vacancy announcements should be considered. For example, in Slovenia open competitions for the SCS are announced in the Official Gazette or in daily newspapers, and in the Employment Service. In Portugal, open competitions are announced in the Official Gazette and are advertised on the public employment website (www.bep.gov.pt), on the Government's electronic platform and also on two other electronic platforms (and optionally in a national newspaper) for 10 days, indicating the formal requirements for nomination, the profile of the required candidate and selection methods.

Further improvements of the application process are needed to make it less burdensome and to extend the reach of vacancy announcements. This can be done by making web pages more user-friendly, limiting the number of documents required for submission in the first stages of the selection process by increasing interoperability

\footnotetext{
${ }^{81}$ For example, a disputed appointment of the secretary general of the Ministry of Trade and Industry. Source: http://www.institutigap.org/news/2113

82 In 2016, as many as $60 \%$ of all SCS positions were occupied by acting civil servants, according to OECD (2017), SIGMA, Monitoring Report: Serbia, OECD, Paris, http://www.sigmaweb.org/publications/Monitoring-Report-2017-Serbia.pdf.

${ }^{83}$ Data collected for the SIGMA 2017 assessments.
} 
between official registers and by requesting copies of documents only and enabling eapplications.

One indicator for equal access to SCS positions is also the representation of women in SCS positions, even though the gender balance varies significantly across the Western Balkans. While the former Yugoslav Republic of Macedonia, Albania, Serbia and the RS all demonstrate similar, positive results (35-41\% of senior civil servants are women), Kosovo is a clear outsider at only $9 \%$.

Table 8. Representation of women in the senior civil service

\begin{tabular}{|l|c|c|c|l|l|l|}
\hline & Albania & BiH & Kosovo & $\begin{array}{l}\text { The former } \\
\text { Yugoslav } \\
\text { Republic of } \\
\text { Macedonia }\end{array}$ & Montenegro & Serbia \\
\hline $\begin{array}{l}\text { Percentage } \\
\text { of women in } \\
\text { SCS } \\
\text { positions }\end{array}$ & $40.5 \%$ & $\begin{array}{c}\text { FBiH: } 20 \% \\
\text { RS: } 36 \% \\
\text { State level: } \\
\text { no data }\end{array}$ & $9 \%$ & $53.8 \% *$ & $30 \%$ & $36 \%$ \\
\hline
\end{tabular}

* Covers state secretaries and heads of sectors in ministries.

Source: Data collected for the SIGMA 2017 assessments.

\subsubsection{Assessment phase}

The common feature of the assessment and testing stage is the non-existence or nonapplication of competency frameworks, relying instead on testing candidates' formal competences and knowledge, with little predictive value placed on performance. The BiH State level is the most advanced, as it has elaborated a competency model and has begun to introduce it. Serbia has designed an elaborate competency model for the SCS, but it has not yet been formally enforced; the FBiH and Montenegro have also begun developing competency frameworks. Albania has listed the competencies required for senior civil servant positions, but has not yet specified their content.

To fully serve the purposes of recruitment, the competency frameworks should define the competences and break them down into levels of accomplishment. Also, the guidelines should be available to selection committees and should containing techniques to assess the competence level of each candidate during the selection process. Such solutions have not been applied so far in most Western Balkans. 
Table 9. Progress in elaborating senior civil service competency frameworks in the Western Balkans

\begin{tabular}{|c|l|l|l|l|c|}
\hline Albania & BiH & Kosovo & $\begin{array}{l}\text { The former } \\
\text { Yugoslav } \\
\text { Republic of } \\
\text { Macedonia }\end{array}$ & Montenegro & Serbia \\
\hline $\begin{array}{c}\text { Competences } \\
\text { listed, not } \\
\text { elaborated }\end{array}$ & $\begin{array}{c}\text { The State level: } \\
\text { implementation } \\
\text { started; } \\
\text { the FBiH and RS: } \\
\text { under development }\end{array}$ & $\begin{array}{c}\text { Competences } \\
\text { listed, not } \\
\text { elaborated }\end{array}$ & Missing & $\begin{array}{c}\text { Under } \\
\text { development }\end{array}$ & $\begin{array}{c}\text { Drafted, not } \\
\text { yet } \\
\text { enforced }\end{array}$ \\
\hline
\end{tabular}

Source: Legislation and data collected by SIGMA for this study.

Without a competency framework, selection committees lack the benchmarks against which to assess candidates, and the usefulness of testing is limited. In such a situation, selection committees tend to focus more on examining candidates' knowledge and experience, which is clearly not sufficient for selection to senior positions.

Another significant problem in checking candidates' qualifications and skills for SCS jobs is that the same examination procedure is used for both internal and external competitors, and the procedures focus more on assessing formal criteria or candidates' knowledge than on their managerial competences. Clearly, the testing systems should be more rigorous and differently designed for external recruitment. In general, written testing should always be obligatory, which is not the case in some administrations, and oral examination should take the form of a structured interview. Written testing increases the transparency and credibility of the selection process and makes it possible to prove that the best candidate was selected; also, certain competencies are easier to check via written tests. Most EU countries use written examinations in the recruitment process for senior positions, and all use interviews ${ }^{84}$. Assessments are most effective and have higher predictive value if they combine various selection methods. For example, in Belgium after curriculum vitae (CV) screening, eligible candidates are invited to undertake a standard computerised assessment, which measures some of the management competencies required for SCS positions. In Estonia, a combination of methods is used including different types of interviews and an essay reflecting the candidate's vision in relation to the position. Also, practical written tasks can be used to check specific skills and interviews with relevant references can provide valuable information on past performance. In the United Kingdom, candidates are assessed against the well-established criteria for competence, skills and experience for each vacancy. The criteria, rules and selection process can vary depending on the type and nature of the role and institution.

Assessment centres can also be used as a comprehensive approach for the selection of senior civil servants. These incorporate a range of assessment techniques, to observe the behaviour of candidates and assess their performance in several dimensions, including interaction between candidates. As a result the predictive value of assessment centres is quite high, but this is also a time-consuming and costly approach,

${ }^{84}$ Kuperus and Rode, (2016), p. 37. 
so should only be considered for the selection of the highest level civil servants, in the last phases of the selection process.

Another important element is the professional composition of selection committees: not only should they not include political positions, but they must be well prepared to undertake selection work and receive relevant training and supporting materials. A higher level of professionalism can be also achieved through opting for permanent selection committee ${ }^{85}$; increasing the powers of a central co-ordination body at the cost of individual institutions; and training members of selection committees to use a variety of selection techniques, including case studies and essays. In Belgium, for example, the Top Team (a unit inside the federal selection bureau SELOR), which is in charge of recruitment, appoints a selection commission of seven members for each position. The Commission is chaired by the head of SELOR (a senior civil servant) or his/her delegate, and members include an external expert in management, an external expert in human resources, two external experts in the field of the vacancy (as technical assessors), and two senior civil servants from at least the same level as the vacant position (but not from the same organisation as the vacancy).

Improving the professionalism of selection committees is important for raising trust in the entire selection procedure. The very small number of candidates for SCS vacancies in most administrations can be explained partly by a lack of trust in selection committees. It must therefore be ensured that, in addition to being respected professionals in the area, committee members must be perceived as neutral and protected from political interference. This can be achieved by excluding politicians from selection committees and not allowing them to appoint selection committee members, or having very clear requirements for committee members if they are appointed by politicians.

\subsubsection{Appointment phase}

While it is crucial to limit political influence and ensure competitiveness in the application and selection phase, in the appointment stage limited political discretion may be allowed to maintain political responsiveness, as is often done in EU member countries. Unfortunately, the appointment stage is one of the weaknesses of many of the Western Balkan administrations, primarily for three reasons.

First, in some administrations the option to appoint acting senior civil servants may be abused. If it happens too frequently and results in abnormally long-time appointment of acting senior civil servants, the purpose of regular recruitment procedures becomes questionable. There are a number of possible solutions to this. For example, in Portugal, the minister must appoint a candidate within 45 days of receiving the shortlist to avoid having a permanent 'acting' official fill the vacancy.

Second, some administrations give too much discretionary power to appointing institutions, which may choose from more than just the two or three highest-ranked

\footnotetext{
${ }^{85}$ There is no one predominant model in the EU requiring having permanent or ad hoc selection commissions. In 2008, seven EU member countries had permanent commissions, while six EU member states had ad hoc committees. Source: Kuperus, H. and Rode, A. (2008), Top Public Managers in Europe: Management and Working Conditions of the Senior Civil Servants in the European Union Member States. Study commissioned by the French EU Presidency. EIPA: Maastricht.
} 
candidates. This happens in Montenegro ${ }^{86}$, at the State level of $\mathbf{B i H}$ and in the $\mathbf{F B i H}$. The practices of some EU member countries could be applied in the Western Balkans to overcome such problems. For example, in Estonia, the Top Civil Servants Selection Committee presents up to three candidates to the person or the body responsible for the appointment decision. In Portugal, the three short-listed candidates are presented to the minister by the Selection Board, and written justification must accompany the appointment decision.

Third, practice shows that giving the appointing entity the right not to choose any of the proposed candidates may result in abuse of this option and reduce the efficiency of the recruitment process.

Therefore, good practice would be to give the employer the choice from among the two to three highest-ranked candidates, but this choice should be preceded by an interview and supported by written justification. Such a solution would create the political acceptance required, while ensuring the transparency and professionalism of the process. Based on the experience of Serbia, where none of the shortlisted candidates are appointed in the vast majority of completed recruitment processes, making it obligatory for the employer to choose one of the presented candidates should be considered.

The institution of acting senior civil servants is necessary to ensure the undisturbed operations of public bodies and to allow time for recruitment processes to be finalised. A good practice is to set a maximum, non-renewable period not exceeding six months for acting positions. And in fact this criterion is met in all Western Balkan legislations except the FBiH.

Despite this provision, however, evidence shows that the percentage of positions occupied by acting senior civil servants in Serbia is extremely high $(60 \%)$, suggesting that merit-based recruitment is not applied in practice. This clearly shows that either legal provisions are not respected, or other ways are found to bypass merit-based recruitment. In this context, it is important to ensure that if the institution of acting senior civil servants is allowed, it should be open only for existing civil servants, and not persons from outside whose qualification is not checked through civil service recruitment procedures.

In the Western Balkan administrations, the right to appeal recruitment decisions is ensured but procedures vary. In some countries, unsuccessful candidates may appeal to the courts, whereas in others it is possible to appeal to either an independent body or to a body created by the government before going to the courts.

\subsubsection{Main findings}

1. The application process in Western Balkan administrations is too burdensome and, in some cases, too costly.

2. A very small number of eligible candidates per position significantly limits the competitive features of recruitment.

\footnotetext{
${ }^{86}$ However, a recently adopted Law on Civil Service and State Employees, entering into force on 1 July 2018, limits it to the three highest-ranked candidates in Montenegro.
} 
3. Many Western Balkan administrations are currently working on developing competency frameworks or have even begun applying them, or are expected to do so soon.

4. Testing systems for open competitions to recruit senior civil servants are not robust and rigorous enough. They mostly assess knowledge and formal requirements rather than competencies needed for senior managerial positions.

5. Members of selection committees are often not equipped with professional selection skills and, in some cases, too much influence is allowed from the ministries that have vacancies.

6. In some cases, appointment practices allowing wide political discretion overrule efforts to establish merit-based recruitment.

7. The option of appointing acting senior civil servants is not used properly in Serbia, which limits the application of proper recruitment procedures in practice.

\subsection{Professional development}

\subsubsection{Responsibility for professional development}

Professional development cannot exist without a responsible institution clearly defined, and resources allocated to development activities, especially at the SCS level. SCS training activities may also be organised in a decentralised manner, but then they will be specific to individual, organisational or policy area needs. As most organisations have only a handful of people belonging to the SCS group, it would be impractical to establish comprehensive programmes for them alone; centrally provided, horizontal courses are therefore the most effective and efficient way of delivering professional development-related activities for senior civil servants. Central provision of training courses does not need to imply a separate institution, however, as the target group is usually quite limited in size. Programmes can be delivered within existing structural units of ministries dealing with civil service issues.

Most Western Balkan administrations have central institutions in place that are either responsible for implementing HRM policies in general for the civil service, including training and development activities (Montenegro ${ }^{87}$, Serbia $^{88}, \mathbf{B i H}^{89}$ ), or even have special schools for that purpose (Albania ${ }^{90}$, Kosovo $^{91}$ ). In Serbia the responsibility for professional development is divided between the Ministry of Public Administration and Local Self-Government (MPALSG) - responsible for programme adoption - and the Human Resource Management Service (HRMS) - for training delivery. In the former Yugoslav Republic of Macedonia, the Ministry of Information Society and Administration is responsible for providing central training courses, but with very limited capacity. In Albania, Serbia and the FBiH, the role of central institutions is more explicit, as they have been mandated to conduct professional development

\footnotetext{
${ }^{87}$ Human Resource Management Authority (HRMA).

${ }^{88}$ Human Resource Management Service (HRMS).

${ }^{89}$ Civil Service Agencies (CSAs) at all administrative levels.

${ }^{90}$ Albanian School of Public Administration (ASPA).

${ }^{91}$ Kosovo Institute of Public Administration (KIPA).
} 
activities specifically for the SCS. In other administrations, their role is rather implicit because the mandate concerns the entire civil service, including the SCS.

Table 10. Responsibility for providing professional development for the senior civil service

\begin{tabular}{|c|c|}
\hline & $\begin{array}{c}\text { Clear responsibility for professional development of the senior civil } \\
\text { service is in place }\end{array}$ \\
\hline \multirow[t]{2}{*}{ Albania } & Explicit \\
\hline & Albanian School of Public Administration (ASPA) \\
\hline \multirow[t]{4}{*}{$\mathbf{B i H}$} & Explicit (FBiH) \\
\hline & Civil Service Agency (CSA) \\
\hline & Implicit (State, RS) \\
\hline & CSAs \\
\hline \multirow[t]{2}{*}{ Kosovo } & Implicit \\
\hline & Kosovo Institute of Public Administration (KIPA) \\
\hline The former & Implicit \\
\hline $\begin{array}{l}\text { Yugoslav } \\
\text { Republic of } \\
\text { Macedonia }\end{array}$ & Ministry of Information Society and Administration (MISA) \\
\hline \multirow[t]{2}{*}{ Montenegro } & Implicit \\
\hline & Human Resource Management Authority (HRMA) \\
\hline \multirow[t]{2}{*}{ Serbia } & Explicit \\
\hline & $\begin{array}{l}\text { Ministry of Public Administration and Local Self-Government } \\
\text { (MPSALG), Human Resource Management Service (HRMS) }\end{array}$ \\
\hline
\end{tabular}

Source: Legislation and data collected by SIGMA for this study.

Where the unit responsible for senior managers' professional development is located is not the most important factor; in EU member countries, many different models are used. More critical is the credibility of the institution in the eyes of the SCS, especially for training systems based on voluntary participation. The institution's reputation depends on its status - whether it is accepted as an equal partner by the SCS. Another important determinant is the quality of development activities the institution is able to provide. If training programmes for the general civil service are not considered attractive, it is very unlikely to earn the trust of the SCS; this is one of the reasons why professional development for senior managers is sometimes separated from training for the rest of the civil service. The institutions responsible for the overall training of civil servants often do not have a good reputation - in fact, civil service training institutions in several EU countries have been reorganised or even closed partly because of reputation issues. Establishing effective SCS training and development in institutions is very difficult, and considerable investment is required to prove the exclusiveness and higher quality of SCS programmes. 
Credibility can be raised through involving international partners and private training or academic institutions that have a reputation and track record for developing senior officials. For instance, the UK civil service has partnered with the London School of Economics (LSE) to develop an Executive Masters of Public Policy degree programme to provide senior and high-potential civil servants with high-level analytical skills ${ }^{92}$. Labelling SCS-related activities separately also gives the impression that these programmes are something completely different from other civil service training activities. Sometimes these measures are not sufficient, however, and the training function must be established in institutions that have better reputations and access to the SCS (e.g. at the centre of government). In these cases, SCS development must not be too isolated from the rest of the civil service, to ensure that programmes are based on the same values.

Another critical factor is resource availability. Several new EU member countries have very effectively employed EU funds to initiate comprehensive civil service training programmes, and the Western Balkan administrations have access to EU pre-accession instruments that may serve the same purpose. However, as with the member countries, this funding should be treated only as an investment to initiate development programmes. To ensure programme sustainability, governments should be ready to take over funding when donor support is gone. The SIGMA 2017 Monitoring Reports revealed that central training funds are extremely limited in the Western Balkans, so substantial improvements would require considerable expansion of central training budgets. Investing in the skills and competencies of the SCS could significantly boost the professionalisation of this group and send the message that the SCS is a government priority, which in turn would raise the attractiveness of working for the SCS. These investments may also have a positive effect on training of the rest of the civil service, when managers begin to understand the value of well-designed and efficiently-conducted training programmes.

\subsubsection{Foundation of development activities}

Development programmes and activities are most effective if they are based on solid evidence of training needs. There are numerous ways of assessing these needs, but one of the most systematic methods is to link them with competency models. These models, if designed properly, should systematically lay out the government's expectations of civil service leaders. They should describe the most important knowledge and skills managers need to possess to be able perform their roles well, and can also provide a structure for selection tools and performance appraisals.

In addition to these expectations, managers' educational, professional and personal backgrounds will dictate their individual training needs. A competency model could also be used to analyse needs at the individual level, as it would provide a structured basis from which to assess the competency gaps of individual managers. Especially when training budgets are limited, a competency model would help to narrow the focus to areas with wider gaps and custom-tailor individual training programmes to the manager's actual needs. It must be kept in mind, however, that a competency model works as a development tool only when it is actively and systematically used

${ }^{92}$ OECD (2017a), p. 73. See also http://www.lse.ac.uk/IPA/EMPP. 
throughout the professional development cycle in conjunction with other HRM tools, especially performance management.

There is no evidence that any of the Western Balkan professional programmes for senior civil servants are based on systematic training needs analysis that combines information from various sources (e.g. performance appraisals, strategic documents, surveys, competency models). Some of these data collection methods may be used to develop certain programmes, but there is no evidence that they are used exclusively for assessing SCS training needs. As Section 2.3.4 will demonstrate, it is questionable whether performance appraisals are effectively conducted in all administrations at the SCS level, so they cannot be relied upon to inform needs analyses. However, several administrations are taking steps to establish competency frameworks, as explained in Section 2.2., which could help them to have a more systematic foundation for their professional development programmes in future. It must be noted, however, that although more than half of EU countries use competency profiles for their SCSs, only ten of them use it for training and development purposes ${ }^{93}$. This shows that putting competency frameworks to effective use is much more difficult than developing them; success depends on having people with relevant expertise and adequate resources in place.

\subsubsection{Training programmes}

As explained above, central training programmes are the most efficient and effective way of developing a country's SCS, and central professional development programmes are a practical tool for building high-performing networks and strengthening SCS esprit de corps. This is especially important in open and position-based civil service systems, the features which can be found in most of the Western Balkan administrations. As the establishment of SCS training systems is just beginning, it would not be logical to design them based on individual needs. Interviews conducted in the course of this study indicate that a lack of basic leadership and management capacities is a common problem across the region, so it would be more practical to start with centrally organised programmes. This would also address the problem of weak co-operation and raise the SCS's capacity to collectively solve crossdepartmental policy issues.

Albania already conducts a comprehensive training programme specifically for the SCS: ASPA's full training programme for TMC civil servants. The programme delivers 5 training modules in 42 days over a 5 -month period ${ }^{94}$, which raises questions about its feasibility, as it should be mandatory for all new senior civil servants. Single modules can also be taken by existing managers. These training activities accommodate a substantial number of SCS employees: there were around $200^{95}$ participations in various training courses organised especially for the SCS by ASPA in

\footnotetext{
${ }^{93}$ Kuperus and Rode, (2016), p. 43.

94 Covering: EU policies and international affairs; strategic planning and policy formulation; competences in strategic and organisational management; public financial affairs; and innovation of administration.
}

95 Number of participations, not participants, so one senior civil servant participating in two training courses will count as two. 
$2016^{96}$. Serbia has also initiated a comprehensive training programme (General Professional Training Programme for Managers), but it targets public managers in general, not only senior civil servants. The programme requires participation in four compulsory modules and three of six optional modules. The HRMS conducted training for two groups in 2016, with 36 people graduating from the course in total. This has been complemented by a comprehensive one-off (eight-day) programme targeted specifically to the SCS. In BiH, there have been different training modules offered at the State level for senior civil servants since 2004. The CSA designed an eight-module programme consisting of two- to three-day courses, and also conducts separate oneday programmes targeted at all managers in general, not only senior civil servants. In 2017, the FBiH began designing a comprehensive 5-module (15-day) programme for the SCS. In Montenegro, the HRMA conducted a small number of one-off seminars for the SCS in 2016; there are no specific managerial training programmes targeted at the SCS in the former Yugoslav Republic of Macedonia, Kosovo or the RS.

Table 11. Training programmes designed for senior civil servants in Western Balkan administrations

\begin{tabular}{|c|c|}
\hline & $\begin{array}{c}\text { Regular professional development programmes available } \\
\text { exclusively for senior civil servants }\end{array}$ \\
\hline Albania & Comprehensive 5-module programme \\
\hline \multirow[t]{3}{*}{ BiH } & FBiH: Comprehensive 15-day programme (introduction in progress) \\
\hline & $\begin{array}{c}\text { State: 8-module programme for managers in general, and 1-day } \\
\text { seminars }\end{array}$ \\
\hline & RS: No \\
\hline Kosovo & No \\
\hline $\begin{array}{l}\text { The former } \\
\text { Yugoslav } \\
\text { Republic of } \\
\text { Macedonia }\end{array}$ & No \\
\hline Montenegro & Small number of one-off seminars offered in 2016 \\
\hline Serbia & $\begin{array}{l}\text { General Professional Training Programme for Managers + special } \\
\text { course for senior civil servants initiated in } 2017\end{array}$ \\
\hline
\end{tabular}

Source: Legislation and data collected by SIGMA for this study.

The common denominator among these initiatives in Albania, BiH, Montenegro and Serbia is international aid, as they have all been supported by donors one way or another. This has strengthened the credibility of the programmes and brought new proficiencies to these areas of the administrations, but the programmes must be designed so that eventually they can be implemented without donor support in terms of

${ }^{96}$ Department of Public Administration, Annual Report 2016. 
both funding and expertise. In some smaller Western Balkan administrations, such expertise is missing even in the private sector, which means it must be established in the public sector. Although this is not always possible or reasonable, in these cases programmes should be designed not to rely solely on external expertise: they should combine local and international expertise to ensure that local needs are met and peculiarities are taken into account.

Interviews conducted during the SIGMA 2017 assessments revealed that several administrations have difficulty attracting senior civil servants to professional development activities. Managers often cite a lack of time, but it may also be a matter of status and prestige (enlisting in a training course might be perceived as a sign of weakness, revealing a lack of confidence in what one is doing). Professional development programme providers therefore need to invest much effort in packaging training activities in a format that suits senior civil servants' work style (e.g. varied activities such as short seminars, scholarships in international business schools, etc.), status (e.g. exclusive events with high-level presenters, attractive training environment) and interests (e.g. interactive and practical workshops directly related to their tasks, peer-to-peer learning, co-creation). Thus, even if training activities are made mandatory, the greatest impact can be achieved by taking these characteristics into account. For example, Estonia's Top Civil Service Excellence Centre tailors its wide array of professional development activities to the development needs assessed according to the competency model. Individual activities include coaching, mentoring, foreign language courses and practical development of certain skills, such as public speaking. Group activities include workshops, joint projects, and tailored development programmes (such as a recent Innovation Boot Camp jointly organised for Estonian, Finnish and Dutch senior civil servants). Belgium's Training Institute of the Federal Administration (TIFA) offers an intensive development programme to empower managers in their own development process by using co-creation. This uses the experience and know-how already present within groups to maximise peer learning and establish strong networks ${ }^{97}$.

Although professional development is underutilised in the Western Balkans, this is not a problem unique to the region, and its importance seems to have been acknowledged in several administrations that have taken concrete steps towards establishing professional development programmes for senior managers. The more systematic and grounded in tangible criteria these programmes are, the more impact they will have.

\subsubsection{Performance appraisal}

Performance appraisals have clearly been established in civil service systems globally, although their practical value is often questioned by both researchers ${ }^{98}$ and civil servants. Their value depends on how the system is designed and whether it fits with the general management framework. Appraisals can have numerous objectives, but for the sake of simplicity they can be divided into two main groups: to manage performance, or to enhance individual development. This distinction is obviously artificial, as individual development ultimately improves the performance of the

\footnotetext{
${ }^{97}$ OECD (2017a), p. 92.
}

98 For instance, https://dupress.deloitte.com/dup-us-en/focus/human-capitaltrends/2017/redesigning-performance-management.html 
individual and, therefore, the organisation, and performance assessment is a perfect tool for mapping development needs. Still, it is useful to analyse which purpose is more explicitly prioritised in legislation. All Western Balkan administrations have stated that performance assessment is the primary purpose of appraisals, i.e. evaluation of achievement of objectives, but they may also assess management competencies as in Albania ${ }^{99}$, the RS, Montenegro ${ }^{100}$ and Serbia ${ }^{101}$. Serbia and the former Yugoslav Republic of Macedonia apply identical rules to the entire civil service, including the SCS.

Interviews conducted during this study indicate that performance appraisals are viewed as a formality with very little practical value by all administrations. The only potential consequence of appraisals that was mentioned (repeatedly) by interviewees was dismissal, although as more of a theoretical possibility. It is good that dismissing senior civil servants based on appraisal results is not a widespread practice, but it is still troubling that none of the administrations is exploiting the full potential of performance appraisals. This also raises concerns about the competency frameworks that are being designed or implemented - if the situation does not change, their value as development tools will be limited when they cannot be linked with appraisals.

Appraisals are complicated at the SCS level, as they must be adjusted to the position of senior civil servants in the hierarchy and their proximity to the political sphere. Senior civil servants' direct superiors are often ministers, and this is sometimes used as an excuse to exclude some SCS sub-groups from appraisal procedures. Albania, BiH, Kosovo and Montenegro have designed distinct appraisal systems for at least some positions within the SCS group, which lay out different appraisal criteria that are more specific to managerial tasks.

Table 12. Overview of senior civil service performance appraisals in the Western Balkans

\begin{tabular}{|l|c|c|c|}
\hline & What is assessed & $\begin{array}{c}\text { Performance appraisal } \\
\text { systems designed for } \\
\text { senior civil servants }\end{array}$ & $\begin{array}{l}\text { Excluded } \\
\text { positions }\end{array}$ \\
\hline Albania & $\begin{array}{c}\text { Performance and } \\
\text { management skills }\end{array}$ & Distinct system & None \\
\hline
\end{tabular}

99 Leadership capacity; management capacity (technical, conceptual); ability to establish co-operative relations; and ability to adapt to change (Decision of the Council of Ministers [DoCM] No. 109 of 2014, amended by DoCM No. 252 of 2016).

100 (1) Organisational skills: strategic and ongoing planning, HRM and management of other resources, the ability to adapt to changes and provide relevant solutions and proposals; (2) managerial skills: relationships with associates, transfer of knowledge and competences, team work and work control; (3) collaborative skills: the level of relations attained and co-operation with citizens, state bodies and other entities, non-governmental organisations and the media; (4) other skills and competences, as well as the quality of doing business: using modern means of labour, negotiation skills, ability to solve problems and disputes (Law on Civil Service and State Employees of 3 August 2016, Official Gazette No. 016/16, Article 111).

${ }^{101}$ Independence, creative ability, initiative, punctuality and diligence, co-operation with other government officials. 


\begin{tabular}{|l|c|c|c|}
\hline BiH & $\begin{array}{c}\text { Performance (State level, } \\
\text { RS, FBiH) } \\
\text { Management skills (RS) }\end{array}$ & Distinct system & None \\
\hline Kosovo & Performance & Distinct system & None \\
\hline $\begin{array}{l}\text { The former } \\
\text { Yugoslav } \\
\text { Macedonia }\end{array}$ & Performance & $\begin{array}{c}\text { General civil service } \\
\text { procedure applies }\end{array}$ & $\begin{array}{c}\text { Secretaries } \\
\text { Heads of state } \\
\text { authorities }\end{array}$ \\
\hline Montenegro & $\begin{array}{c}\text { Performance and } \\
\text { management skills }\end{array}$ & Distinct system & $\begin{array}{c}\text { Heads of state } \\
\text { authorities }\end{array}$ \\
\hline Serbia & $\begin{array}{c}\text { Performance and } \\
\text { management skills }\end{array}$ & $\begin{array}{c}\text { General civil service } \\
\text { procedure applies }\end{array}$ & $\begin{array}{c}\text { Heads of state } \\
\text { authorities }\end{array}$ \\
\hline
\end{tabular}

Source: Legislation and data collected by SIGMA for this study.

Performance appraisals are a useful feedback tool for assessing professional development needs and ensure a more systematic approach to professional development. It makes good sense, however, to design a specific assessment system for the SCS, as is done in all EU member countries, because the generic criteria applied to the entire civil service are not precise and practical enough to evaluate the performance of senior managers. For example, the professional development needs of senior civil servants in Ireland are identified through the setting of development objectives, informed by 360 degrees feedback. Depending on the development needs, they can be addressed by the individuals themselves or by the central Senior Public Service team ${ }^{102}$.

All Western Balkan administrations have relevant legislation in place that also covers the SCS, at least to some extent, but there is little evidence of its effective use. Even though appraisals are mandatory, the SIGMA 2017 assessments revealed that there are often problems of compliance with this requirement at the general civil service level. Serious doubts about the actual use of appraisals, especially at the SCS level, were also expressed in interviews.

\subsubsection{Main findings}

1. Professional development is not well organised in the Western Balkan administrations, except in Albania, which has put much emphasis on creating a professional development system specific to the SCS. At the State level in BiH, specific training programmes have been offered for senior civil servants, and the $\mathbf{F B i H}$ and Serbia have recently invested in establishing professional programmes for the SCS.

2. Although most of the countries have created special institutions for public service management, including training and development, they do not provide

${ }^{102}$ Kuperus and Rode, (2016), p. 54. 
enough systematic and regular programmes specially designed for the SCS, except in Albania.

3. Professional development does not have systematic grounding, as competency models are still missing in most countries and no other tools are used to comprehensively assess senior-level training needs.

4. Performance appraisal systems are formally in place, but even if appraisals are conducted, they are not linked to professional development activities. The only apparent practical value of appraisals is as grounds for dismissal, although they are not used this way in practice.

\subsection{Termination of employment}

\subsubsection{Dismissals and demotions}

Most of the Western Balkan administrations studied have legislation limiting discretionary dismissals, while enabling it in justifiable cases. Provisions concerning senior civil servants are the same as for other civil servants in some administrations (BiH, Montenegro, Kosovo and the former Yugoslav Republic of Macedonia for Bcategory civil servants), and in others additional reasons for dismissal are possible (Albania and Serbia). Albania is a special case because of its TMC concept. In that country, although it is relatively easy to release senior civil servants from their positions, they have a certain amount of employment stability because when dismissed from the position, they return to the TMC and can be appointed to another one, unless there is a clear justifiable reason for their dismissal from the civil service.

The former Yugoslav Republic of Macedonia deserves separate comment, as its highest senior managerial positions (A-category) can be discretionally dismissed from their secretary position, consequent to their discretional appointment, and disciplinary procedures do not apply to these positions. The second level below the minister (B-category positions) submit to the same (or almost the same) dismissal and disciplinary procedures as other civil servants. Thus, because no relevant procedures are applied to A-category positions, only category-B civil servants will be analysed in this chapter.

Legislation regulates the issue of possible reasons for dismissal from the civil service in Western Balkan administrations. In most cases, it does not allow dismissals for reasons other than termination of the appointment period, disciplinary or judicial procedures, recurrent negative performance over a sufficiently long period, and redundancy due to restructuring or downsizing. This is the case for Albania, Montenegro and BiH. The issue that deserves more discussion, however, is dismissal of senior civil servants following negative performance appraisals. In principle, the right to dismiss senior civil servants when they repeatedly receive negative appraisals is justifiable, as it is one of the most important measures to ensure the accountability of higher managers ${ }^{103}$. However, it must be stressed that dismissal after just one negative performance appraisal (as is the case in Kosovo and the former Yugoslav Republic of Macedonia) is problematic, as it is unfair and may give incentives for politicallydriven dismissals. Moreover, the primary objective of performance appraisals is to

103 There are, however, EU countries that do not link performance appraisals to dismissals, promotions, etc. (Estonia). 
provide senior civil servants with work-related feedback enabling them to improve their performance. It is therefore necessary to allow them the opportunity to take corrective measures after the first negative feedback; this implies that sufficient time to improve performance (e.g. by attending additional training, coaching, etc.) must be permitted. Hence, measures applied in Serbia, which allow dismissal after two negative appraisals with a very short time between them (the second appraisal takes place only 30 days after the first), are also improper. In SIGMA's opinion, dismissals could take place after two consecutive, objective and justified negative performance appraisals, which are conducted over a sufficiently long time period.

It is also important to avoid formulating reasons for dismissal too vaguely (e.g. 'serious disturbance') without defining the terms (as in the case of Serbia). Another disputable solution applied in Serbia is allowing for the dismissal of senior civil servants at the request of the anti-corruption agency or the Ombudsman, without an impartial investigation or allowing the civil servant the right and opportunity to defend him/herself.

Table 13. Dismissal of senior civil servants

\begin{tabular}{|c|c|}
\hline & $\begin{array}{l}\text { Legal provisions regarding dismissals : } \\
\text { Civil service legislation only allows the dismissal of senior civil servants } \\
\text { in case of termination of the appointment period, disciplinary or judicial } \\
\text { procedures, recurrent negative performance appraisals, redundancy } \\
\text { due to restructuring or downsizing, or other objective criteria. }\end{array}$ \\
\hline Albania & Yes \\
\hline $\mathbf{B i H}$ & Yes \\
\hline Kosovo & No (too easy to dismiss after negative performance appraisal) \\
\hline $\begin{array}{l}\text { The former } \\
\text { Yugoslav } \\
\text { Republic of } \\
\text { Macedonia }\end{array}$ & No (too easy to dismiss after negative performance appraisal) \\
\hline Montenegro & Yes \\
\hline Serbia & $\begin{array}{l}\text { No (subjective criteria and too easy to dismiss after negative performance } \\
\text { appraisal) }\end{array}$ \\
\hline
\end{tabular}

Note: This table relates to dismissal from the civil service, not from the position.

Source: Legislation and data collected by SIGMA for this study.

SIGMA received very limited evidence on SCS turnover rates for its 2017 Monitoring Reports. However, based on information available the rate appears to be low in Kosovo (6\% of senior civil servants left their positions in 2016) and somewhat higher in Albania (around 18\%), although those released from their positions were returned 
to the pool and could have been assigned to other senior positions. In Montenegro, the turnover after the last elections (November 2016 to May 2017) exceeded 20\% ${ }^{104}$.

As indicated in the section on recruitment, recruitment procedures in some Western Balkan administrations are invalidated by the practice of appointing acting heads. Acting heads usually do not have job stability, as they can be dismissed at any moment without justification. Thus, abusing the right to appoint acting senior civil servants not only undermines professionalisation of the civil service, it could result in overdependence of political superiors and discontinuity in public administration operations.

When analysing dismissals, attention should also be paid to whether regulations on demoting senior civil servants ensure sufficient transparency and merit. Provisions ensuring that after the end of a term senior civil servants can return to a comparable position are of crucial importance, as this minimum guarantee will encourage civil servants to accept senior positions.

Special attention should be paid to the practice of mandatory transfers resulting in, for example, reorganisation of public bodies, which may invite opportunities for misuse.

\subsubsection{Disciplinary procedures}

Across the region, disciplinary procedures for senior civil servants do not differ significantly from those applied to other civil servants, except that very often the body responsible for initiating or conducting the procedures is different. Disciplinary procedures for the SCS are conducted in Albania by the National Selection Committee; in Serbia by the High Civil Service Council; and in the former Yugoslav Republic of Macedonia and in Montenegro by a government-appointed disciplinary commission. In all the administrations, disciplinary commissions are appointed by the government and consist of senior civil servants, and frequently external experts. The only exception is Kosovo, where disciplinary commissions are not only created by the Government, but consist of politicians (apart from secretaries general). In the former Yugoslav Republic of Macedonia, disciplinary procedures for the highest civil servants (category A) are not regulated at all because these positions are politically appointed.

In almost all of the administrations, the legislation upholds the basic principles related to disciplinary procedures ${ }^{105}$. Moreover, in most of them ${ }^{106}$ the disciplinary procedures comply with the essential procedural principles ${ }^{107}$.

${ }^{104}$ Ministry of Public Administration (2017), Annual Report on Implementation of Action Plan Implementing 2016- 2020 Public Administration Reform Strategy, p. 27.

105 Civil servants' obligations are regulated; breach of those obligations should lead to disciplinary proceedings; the list of disciplinary sanctions is exhaustive and contains a sufficient range of sanctions; the principle of proportionality is explicitly stated; and circumstances that aggravate or extenuate disciplinary sanctions are stated.

${ }^{106}$ With the exception of the former Yugoslav Republic of Macedonia where the right to access documents and the presumption of innocence are not explicitly stated in legislation.

${ }^{107}$ Presumption of innocence; the right of civil servants to defend themselves; the right to use legal advice; the right of accused civil servants to access the relevant documents on which charges are based; the right to a hearing, either oral or written, prior to the disciplinary 
In addition to these provisions, it is important to set reasonable limits in the legislation to protect civil servants from anyone seeking revenge by starting a disciplinary procedure for offences committed many years ago, while also ensuring that the prescription period for punishing disciplinary wrongdoings is not too short. Only Albania's legislation fully complies with these time limitations, whereas Serbia's does not set any. In Montenegro ${ }^{108}$, Kosovo and BiH, some of the limits are set out in legislation, but others are not.

Table 14. Protection of senior civil servant rights in disciplinary procedures

\begin{tabular}{|c|c|c|c|c|c|c|}
\hline & Albania & $\mathbf{B i H}$ & Kosovo & $\begin{array}{l}\text { The former } \\
\text { Yugoslav } \\
\text { Republic of } \\
\text { Macedonia }\end{array}$ & Montenegro & Serbia \\
\hline $\begin{array}{l}\text { Adequacy of civil } \\
\text { service } \\
\text { legislation to } \\
\text { uphold basic } \\
\text { principles of } \\
\text { disciplinary } \\
\text { procedures }\end{array}$ & Yes & $\begin{array}{l}\text { Partly (only } \\
\text { the RS fulfils } \\
\text { the criteria) }\end{array}$ & Partly & Yes & Yes & Yes \\
\hline $\begin{array}{l}\text { Compliance of } \\
\text { disciplinary } \\
\text { procedures with } \\
\text { essential } \\
\text { procedural } \\
\text { principles }\end{array}$ & Yes & Yes & Yes & No & Yes & Yes \\
\hline $\begin{array}{l}\text { Adequate time } \\
\text { limits for the } \\
\text { administration to } \\
\text { initiate } \\
\text { disciplinary } \\
\text { action and/or } \\
\text { punish } \\
\text { misbehaviour }\end{array}$ & Yes & $\begin{array}{l}\text { Partly (the } \\
\text { State level and } \\
\text { the FBiH do } \\
\text { not } \\
\text { differentiate } \\
\text { between } \\
\text { minor and } \\
\text { major } \\
\text { violations) }\end{array}$ & Partly & Partly & Partly ${ }^{109}$ & No \\
\hline
\end{tabular}

Source: Data collected for the SIGMA 2017 assessments.

Overall, legislation in the Western Balkans protects the rights of civil servants during disciplinary procedures, except in in Kosovo, where protection against political

authority issuing any resolutions; the right to appeal; and the right to be heard during the appeal procedure.

${ }^{108}$ The recently adopted Law on Civil Service and State Employees in Montenegro improves the situation by extending the time limit to initiate disciplinary procedures in cases of severe violation of duties.

${ }^{109}$ The recently adopted Law on Civil Service and State Employees of Montenegro improves the situation by extending the time limit to initiate disciplinary procedures in cases of severe violation of duties. 
influence is low because politicians can be part of disciplinary commissions. The other exception concerns the highest (A-category) civil servants in the former Yugoslav Republic of Macedonia, for whom there are no provisions related to disciplinary procedures.

\subsubsection{Appeals}

All the Western Balkan administrations regulate the right to appeal disciplinary procedures and, in the case of dismissal, the right to be heard in appeal procedures. Solutions differ, however: in the administrations in which the government appoints senior civil servants, they usually need to appeal directly to the court (for example in Serbia and the RS). In Albania, senior civil servants are appointed by the Department of Public Administration, and they also must appeal to the courts. Some other administrations have independent appeal bodies (for example Kosovo and the former Yugoslav Republic of Macedonia, where B-category civil servants can appeal to the Agency for Administration), and in other administrations both administrative and court appeals are possible (in Montenegro, the BiH State level and the FBiH, where appeals are first filed to an appeals commission/board appointed by the Government, after which recourse to the court is possible).

\subsubsection{Main findings}

1. Legislation in most of the Western Balkan administrations provides a solid legal basis concerning dismissal of senior civil servants. The main problem is the possibility of dismissal after one negative performance appraisal in some administrations.

2. Legislation in most Western Balkan administrations contains well-drafted provisions for disciplinary procedures for senior civil servants that do not differ substantially from disciplinary procedures for the rest of the civil service.

3. The right to appeal dismissal decisions and disciplinary rulings is ensured in the legislation of the Western Balkan administrations.

\subsection{Policy co-ordination and management of the senior civil service}

\subsubsection{Responsibility for senior civil service policy co-ordination and management}

None of the Western Balkan administrations has a special authority or body dealing with the SCS. Thus, the agencies responsible for the entire civil service are covering SCS matters, which in practice means little attention and the lack of a comprehensive approach to the development of the SCS. Moreover, not all civil service agencies are positioned where they could benefit from the influence of a minister who may support SCS development. In Montenegro and the former Yugoslav Republic of Macedonia, for example, the civil service bureau is not formally subordinated to the ministry responsible for public administration, although informally they may co-operate very closely.

SCS management is strongest in Albania. The Department of Public Administration (DoPA), which until the 2017 change of Government reported to the Minister for Public Administration and since then to the Deputy Prime Minister responsible for PAR, formally under the Prime Minister, plays a major role in managing the civil service overall by developing policies and legislation, and guiding their 
implementation. DoPA has a structure dedicated to managing TMC procedures, called the Technical Secretariat for the TMC and composed of three civil servants directly responsible for dealing with the TMC. Under DoPA is ASPA, and part of its explicitly defined role is to conduct training for senior public managers and candidates for these positions. Finally, the independent Commissioner for Civil Service Monitoring (CCSM) reports to the Parliament on a yearly basis.

In Kosovo, the Council on Senior Management Positions (CSMP) provides strategic leadership in the appointment and administration of senior management positions. The CSMP is expected to meet at least once every three months, but in practice it meets less often. Also, this seven-member political body led by the Deputy Prime Minister and supported by the Office of the Prime Minister is geared more towards appointments than to the broad management of this group. In addition, the Ministry of Public Administration plays a role in managing the rest of the civil servants and also collects information about civil service recruitment in some, but not all, bodies in which a senior management concept should be applied. Similar to Albania, Kosovo has an Independent Oversight Board (IOB) for Civil Service. Its threefold role is to: i) oversee the application of rules and principles of legislation related to the civil service; ii) process and decide on complaints filed by civil servants against decisions of employing authorities; and iii) verify whether appointments to civil service management positions at the level of heads of departments comply with the CSL. The IOB is not currently involved in SCS recruitment in any way, but a draft law has been prepared granting it the legal competence to monitor the process.

In the former Yugoslav Republic of Macedonia, the CSL designates three institutions as civil service management bodies: the MISA, the Ministry of Finance $(\mathrm{MoF})$, and the Secretariat for Implementation of the Ohrid Framework Agreement (SIOFA) in special cases of group hiring. The role of the MISA is not only to develop policies and regulations in the HRM area, but also to organise training and keep records. The MoF's role is to approve annual administrative servant hiring plans and funds prior to recruitment for individual positions; no roles specific to the SCS are envisaged. Civil service recruitment is organised by the independent Agency for Administration, which also acts as the appeal body.

In Montenegro and Serbia, central civil service agencies (the Human Resources Management Authority in Montenegro and the Human Resources Management Service in Serbia) perform technical HRM-related tasks in state administration. They both have rather extensive roles that include preparing HR plans for the state administration and government services, advising government authorities on HR matters, organising professional development programmes for civil servants, supporting the Government's appeal committee, keeping HR records and publishing vacancy announcements. In Serbia, however, there is also a High Civil Service Council responsible for prescribing methods to assess competencies in the selection process and for setting criteria for civil service appointments. It also adopts the code of ethics, establishes selection committees from among its members to fill vacant SCS positions, and takes disciplinary measures against senior civil servants.

In BiH, central civil service institutions (civil service agencies at the State level and in the FBiH, and the Agency for State Administration in the RS) are the key HRM institutions for the entire civil service. Their main functions are to plan and implement core HRM functions (keeping records, recruitment, training, ethics) for all categories of civil servants. In addition, central civil service bodies provide expert advice to 
various individuals and institutions on day-to-day HRM affairs. When it comes to developing legislation, however, the agencies share responsibilities with the relevant ministries (justice ministries at the State and FBiH levels, and the MPALSG in the RS). One of the most important functions of central HRM bodies in $\mathrm{BiH}$ is administering recruitment procedures, part of which is the right to appoint two (in the $\mathrm{FBiH}$ and the RS) or even three (at the State level) members of the five-person selection panel.

Table 15. Management functions in relation to civil service

\begin{tabular}{|c|c|c|c|c|c|}
\hline & $\begin{array}{l}\text { Developing } \\
\text { policy and } \\
\text { central co- } \\
\text { ordination }\end{array}$ & $\begin{array}{l}\text { Recruitment } \\
\text { and selection }\end{array}$ & $\begin{array}{l}\text { Training } \\
\text { and } \\
\text { developmen } \\
\text { t }\end{array}$ & $\begin{array}{l}\text { Management } \\
\text { of records }\end{array}$ & $\begin{array}{l}\text { Reporting to } \\
\text { the public }\end{array}$ \\
\hline Albania & DoPA & $\begin{array}{l}\text { National } \\
\text { Selection } \\
\text { Committee; } \\
\text { DoPA }\end{array}$ & ASPA & DoPA & CCSM; DoPA \\
\hline BiH State & $\begin{array}{l}\text { Ministry of } \\
\text { Justice }\end{array}$ & CSA & CSA & CSA & CSA \\
\hline FBiH & $\begin{array}{l}\text { Ministry of } \\
\text { Justice }\end{array}$ & CSA & CSA & CSA & CSA \\
\hline BiH RS & MPALSG & $\begin{array}{l}\text { Agency for } \\
\text { State } \\
\text { Administration } \\
\text { (ASA) }\end{array}$ & ASA & ASA & ASA \\
\hline Kosovo & MPA & CSMP & KIPA & MPA & $\begin{array}{l}\text { No such } \\
\text { requirement }\end{array}$ \\
\hline $\begin{array}{l}\text { The former } \\
\text { Yugoslav } \\
\text { Republic of } \\
\text { Macedonia }\end{array}$ & MISA & $\begin{array}{l}\text { Ministers select } \\
\text { Category A } \\
\text { candidates; } \\
\text { Agency of } \\
\text { Administration } \\
\text { (AA) for } \\
\text { selection of } \\
\text { other civil } \\
\text { servants }\end{array}$ & MISA & MISA & AA; MISA \\
\hline Montenegro & MPA & HRMA & HRMA & HRMA & HRMA \\
\hline Serbia & MPALSG & $\begin{array}{l}\text { HRMS; High } \\
\text { Civil Service } \\
\text { Council }\end{array}$ & HRMS & HRMS & $\begin{array}{l}\text { No such } \\
\text { requirement }\end{array}$ \\
\hline
\end{tabular}

Note: Bold indicates that functional responsibilities in relation to the senior civil service are clearly assigned by law. The Albanian National Selection Committee, Serbian High Civil Service Council and the Kosovar CSMP are the three institutions specifically created for the management of top civil servants.

Source: Legislation and data collected by SIGMA for this study.

Analysis of PAR programmes shows that developing the SCS is not comprehensively addressed in any of the Western Balkan administrations. At best, rather specific 
objectives relate to it: for example, depoliticising the SCS in Serbia ${ }^{110}$, and in Montenegro developing standards and procedures to select candidates for senior public administration management positions. Montenegro's PAR Strategy therefore prioritises establishing a competency framework and prescribes procedures for selecting heads of authorities and senior managerial staff. But in most administrations, no objectives have been set for the SCS, which decreases the likelihood of substantial progress in this area.

Furthermore, none of the administrations has a senior civil servant who can be identified as the head of the civil service and responsible for management of the SCS.

Overall, although most of the administrations have bodies generally responsible for the civil service, they usually do not address policy development needs or pay special attention to the recruitment and professional development of senior civil servants. In most cases, the tasks of such bodies are predominantly technical-administrative and record-keeping and data collection functions are very limited. All this implies that they are not properly equipped to formulate the analyses needed to advance policy development and to meet the standards of proper public reporting on the SCS.

\subsubsection{Main findings}

1. No central units, except in Albania, deal exclusively with the SCS; instead, issues concerning the SCS are handled by civil service offices along with overall civil service co-ordination and management. There is little evidence that civil service co-ordination units consider the SCS a priority area or pay special attention to it.

2. Central civil service offices play a more technical-assistive than strategic role concerning the SCS. Very initial steps have been taken by some offices (BiH State level, Montenegro, Serbia) to come up with competency frameworks that would allow a more integrated approach to SCS management.

3. There is a lack of specific government policy for the SCS. PAR strategies do not usually address the needs of this group specifically, and when objectives touch upon senior civil servants, they only deal with specific aspects of the SCS.

\footnotetext{
${ }^{110}$ Public Administration Reform Strategy in the Republic of Serbia, Official Gazette No. 9/14
} and 42/14-corr., adopted on 24 January 2014. 


\section{A way forward and ideas for improvement}

Building a professional SCS involves developing both professional competence and political responsiveness. This analysis of the state of the play in the SCS in Western Balkan administrations demonstrates that, despite considerable efforts to establish a sound legal basis, most of the current systems are not yet capable of producing professional-level SCS competence. In practice, the crucial components required for a professional SCS are missing, so professional competence is often outranked - and in some cases even overruled - by political interference. The crucial components that are weakly institutionalised or are not functioning in practice include: (a) clearly defined roles, responsibilities and accountability lines; (b) the ability to appeal to, and attract, a wide pool of candidates; (c) rigorous testing to comprehensively and systematically screen competence levels; and (d) independent and professional selection committees to test professional competence levels.

Change is needed not only in practices but also in the overall culture, to be able to implement principles of merit effectively. Initial steps have been taken, but further professionalisation of the SCS should be prioritised across the region through a longterm and consistent strategic approach that must not be questioned or reversed after changes in government. Wider political consensus for building a merit-based SCS should therefore be sought, the main motive being that a professional, high-performing SCS is a valuable partner in helping governments implement policies effectively and efficiently.

The context of each public administration is a determining factor for introducing reforms, and although there is no single solution for building a truly professional SCS, certain components are fundamental in every model. The key components are outlined in the analytical framework of this paper, which may be used as a helpful source for administrations implementing relevant processes, legal provisions, systems and capacities for developing and refining professional SCSs. The input of both politicians and senior civil servants is crucial for designing, implementing and maintaining reforms. Thus, decisions for taking such reforms further will require political leadership and wide consensus, as well as mutual trust and long-term commitment from both politicians and senior officials.

The primary message of this paper is that the whole region place professionalisation of the SCS (i.e. creating a system that produces professional competence at the SCS level) at the top of the political agenda. Based on analysis of current practices in the Western Balkan administrations studied, the following specific recommendations have been formulated to point the way toward further professionalisation of the SCS. 
1. Obtain wide political consensus on building a professional SCS and on respecting the principle of merit. Consensus must include parties currently in the opposition.

- Discuss and reach agreement on what professionalisation means in each administration's context, why it is necessary and what the greatest obstacles are to its attainment.

- Develop a clear policy for SCS professionalisation, focusing on removing obstacles and prioritising the key steps in each administration's context.

- Establish and maintain high-level political support to ensure that policies are implemented in practice, including proper legislation, establishment of implementation capacity, strictly merit-based staffing and the functional professional development of senior civil servants.

- Establish regular monitoring and public reporting on implementation of the measures for professionalising the SCS.

2. Clearly describe the roles of each position - both political and SCS - within the hierarchy of executive organisations.

- Reach agreement on who is responsible for what, delineating the division of roles and responsibilities of SCS versus political positions. Ensure that clarity is established (expressed in legislation and followed in practice) at the highest level of the SCS in the ministry, and for the heads of bodies under the ministry.

- In legislation, delegate sufficient decision-making powers and relevant managerial responsibilities directly to SCS positions to avoid overburdening ministers with administrative matters and to equip the SCS with proper managerial rights and responsibilities.

- Eliminate multiple, overlapping accountability lines to make everyone in the hierarchy accountable for their decisions.

3. Clearly define the horizontal and vertical composition of the SCS.

- Delineate SCS positions clearly in law. To ensure equal treatment, clearly express the principle of merit and the political impartiality of these positions.

- Consistently apply the SCS concept to heads of bodies within ministries and to bodies with executive authority to ensure equal treatment and to support the development of common SCS values and ethos.

- Review and revise employment conditions of the SCS, ensuring that they enable SCS stability and neutrality, and attract and retain competent, highperforming people.

4. Agree on measures to effectively limit political interference in SCS recruitment and selection. Candidates for SCS positions should be comprehensively tested for professional competence before a minister, the prime minister or government are given the opportunity to take final selection decisions. It must be understood that, in the long term, the SCS can only be committed and professionally prepared to implement governments' political programmes, and create an organisation with the necessary capacities, if its professional competence and independence are ensured from the start.

- Review and revise legal provisions that allow undue political influence on SCS stability (service terms linked to terms of government, non-merit-based appointment procedures, dismissal after one negative performance appraisal, frequent use of acting senior civil servants for long periods, etc.). 
- Communicate widely (including through the media and in civil society) the aim of SCS professionalisation, and measures undertaken to limit political interference and support a political culture respectful of SCS professionalisation.

5. Attract qualified applicants to SCS vacancies to increase competitiveness and the level of competitions.

- Find out what the reasons are for the small number of candidates in the administration's context, eliminate relevant barriers, cut excessive bureaucracy, make the process more user-friendly and improve access, as appropriate.

- Invest in confidence-building measures (open advertising, sufficiently long application deadlines, transparent processes and clear selection criteria, etc.) to build trust in the recruitment process.

- Consider attracting more professional candidates by using targeted searches inviting potentially strong candidates to apply in open competitions.

- Consider creating special succession programmes for the SCS (for example, for selected middle-management civil servants with senior management potential) to increase the number of potential candidates for SCS positions.

6. Invest in a professional and merit-based recruitment process.

- Ensure the independence of selection committees so that selected and appointed candidates can be trusted to be politically neutral. Consider establishing permanent professional, neutral selection committees by legislation.

- Significantly improve the capacities of central selection committees through specialised training and guidance, or establish autonomous assessment centres.

- Improve selection techniques to make the selection process more effective and provide the best choice of candidates. Use a combination of selection methods tailored to testing competencies needed for SCS positions.

- Ensure that political discretion in recruitment, selection, and especially appointment, does not overrule the principle of merit. Clearly define the limits of political discretion in the recruitment process.

7. Continue elaborating and implementing competency frameworks for the SCS to set requirements for expected competencies, to structure and guide recruitment and testing of candidates, and to serve as a basis for professional development.

- Define the essential competencies, and provide full descriptions of these competencies to clearly communicate the expected skills, knowledge and behaviour of senior civil servants.

- Prepare relevant legislation and guidelines to implement competency-based recruitment and selection.

- Elaborate a system to identify the professional development needs of the SCS based on the competency model.

\section{Invest in enhanced SCS competence.}

- Create special training programmes for the SCS to ensure sufficient preparatory training and on-the-job professional development.

- Elaborate tailored development activities to enable capacity improvement, support networking and strengthen the collective identity of the SCS. 
- Create mobility schemes to retain talented senior civil servants and contribute to the professionalism and stability of the SCS.

- Consider cross-country co-operation to build SCS capacity, by elaborating joint development programmes for cross-cutting and common development needs.

9. Strengthen the role of the central units responsible for the SCS so that a professional approach and adequate attention can be devoted to building a professional SCS.

- Define the roles and responsibilities for SCS co-ordination and overall management.

- Designate substantial policy development tasks to this unit, including proper data collection, analysis and public reporting on the SCS.

- Invest in building the unit's capacity, both its specialised SCS skills and knowledge, and its financial resources. 


\section{Annex 1. Framework for professionalisation of the senior civil service}

\begin{tabular}{|c|c|}
\hline $\begin{array}{l}\text { Area of SCS } \\
\text { development }\end{array}$ & Key components \\
\hline \multirow{5}{*}{$\begin{array}{l}\text { 1. SCS Composition } \\
\text { and Employment } \\
\text { Conditions }\end{array}$} & $\begin{array}{l}\text { 1.1. Appropriate and clearly defined SCS, both vertically and } \\
\text { horizontally }\end{array}$ \\
\hline & 1.2. Clearly defined accountability lines \\
\hline & 1.3. Well-defined SCS roles and responsibilities \\
\hline & 1.4. Length of service supports mobility and continuity of the SCS \\
\hline & $\begin{array}{l}\text { 1.5. Conditions applied to the SCS support integrity, neutrality and } \\
\text { attractiveness of SCS positions }\end{array}$ \\
\hline \multirow{9}{*}{$\begin{array}{l}\text { 2. Merit-based } \\
\text { recruitment and } \\
\text { selection }\end{array}$} & 2.1. Clear, non-discriminatory and appropriate eligibility criteria \\
\hline & $\begin{array}{l}\text { 2.2. Approachable, reasonable and transparent application process } \\
\text { through competition }\end{array}$ \\
\hline & $\begin{array}{l}\text { 2.3. Relevant professional competency profiles to communicate expected } \\
\text { performance and competencies needed }\end{array}$ \\
\hline & 2.4. Merit-based recruitment and selection through competition \\
\hline & 2.5. Selection criteria relevant for SCS positions \\
\hline & $\begin{array}{l}\text { 2.6. Testing methods that comprehensively screen professional } \\
\text { competence }\end{array}$ \\
\hline & 2.7. Professional, neutral and well-informed selection committees \\
\hline & $\begin{array}{l}\text { 2.8. Transparent and timely appointment, ensuring both principle of } \\
\text { merit and political acceptance }\end{array}$ \\
\hline & 2.9. Effective appeal system \\
\hline \multirow{4}{*}{$\begin{array}{l}\text { 3. Professional } \\
\text { development }\end{array}$} & 3.1. Body for central professional development of SCS in place \\
\hline & 3.2. Professional development system based on competency profiles \\
\hline & 3.3. Professional development system tailored to SCS needs \\
\hline & $\begin{array}{l}\text { 3.4. Objective performance appraisal system supporting professional } \\
\text { achievement }\end{array}$ \\
\hline $\begin{array}{l}\text { 4. Termination of } \\
\text { employment }\end{array}$ & $\begin{array}{l}\text { 4.1. Dismissal, transfer and demotion of SCS is fair and based on } \\
\text { objective criteria }\end{array}$ \\
\hline
\end{tabular}




\begin{tabular}{|c|c|}
\hline & 4.2. Disciplinary procedures are transparent and objective \\
\hline & $\begin{array}{l}\text { 4.3. The rights of senior civil servants are protected during dismissals, } \\
\text { demotions and disciplinary procedures through an appeal system }\end{array}$ \\
\hline \multirow{2}{*}{$\begin{array}{l}\text { 5. SCS policy co- } \\
\text { ordination and } \\
\text { responsibility for } \\
\text { management } \\
\text { of SCS }\end{array}$} & $\begin{array}{l}\text { 5.1. Policy for SCS co-ordination, development and management is in } \\
\text { place }\end{array}$ \\
\hline & $\begin{array}{l}\text { 5.2. Responsible central body with sufficient authority, resources and } \\
\text { capacities for SCS management }\end{array}$ \\
\hline
\end{tabular}

Source: SIGMA (based on the SIGMA Principles of Public Administration and OECD analytical work on the SCS used in Government at a Glance, 2017). 


\section{Annex 2. Management hierarchy of ministries in the Western Balkans}

\section{Legend}

Blue: Political positions generally not covered in civil service legislation

Yellow: Top civil service positions recognised by CSL

Red line: Delineates different categories of officials, such as political positions or senior civil service positions. Explanations of the category are provided in red boxes.

\section{Albania}

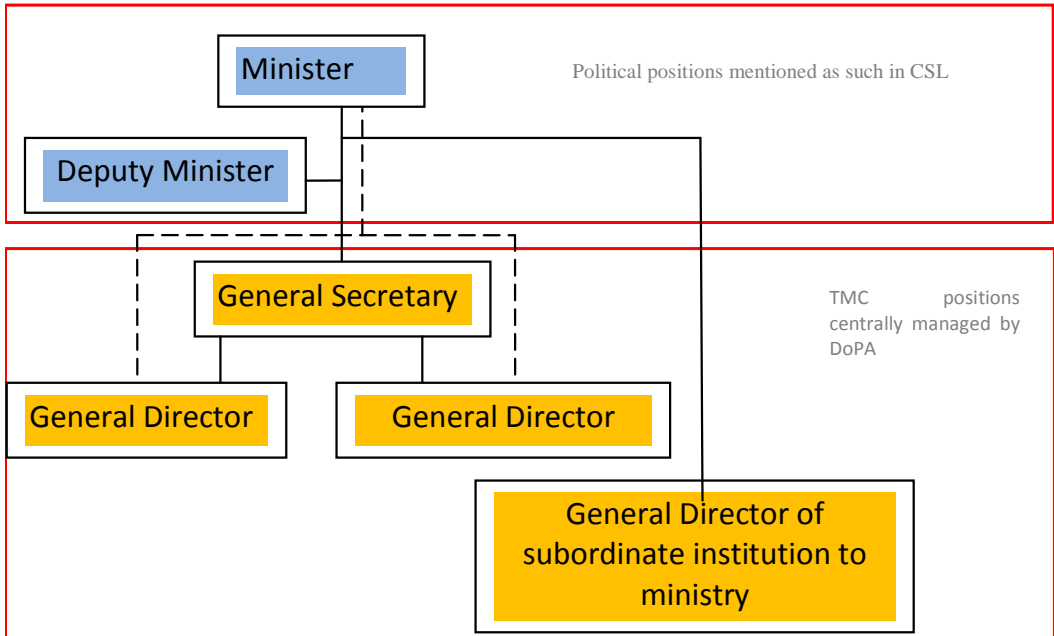

Assembly

General Director

Notes: TMC $=$ Top Management Corps; DoPA $=$ Department of Public Administration. 


\section{Bosnia and Herzegovina, State level}

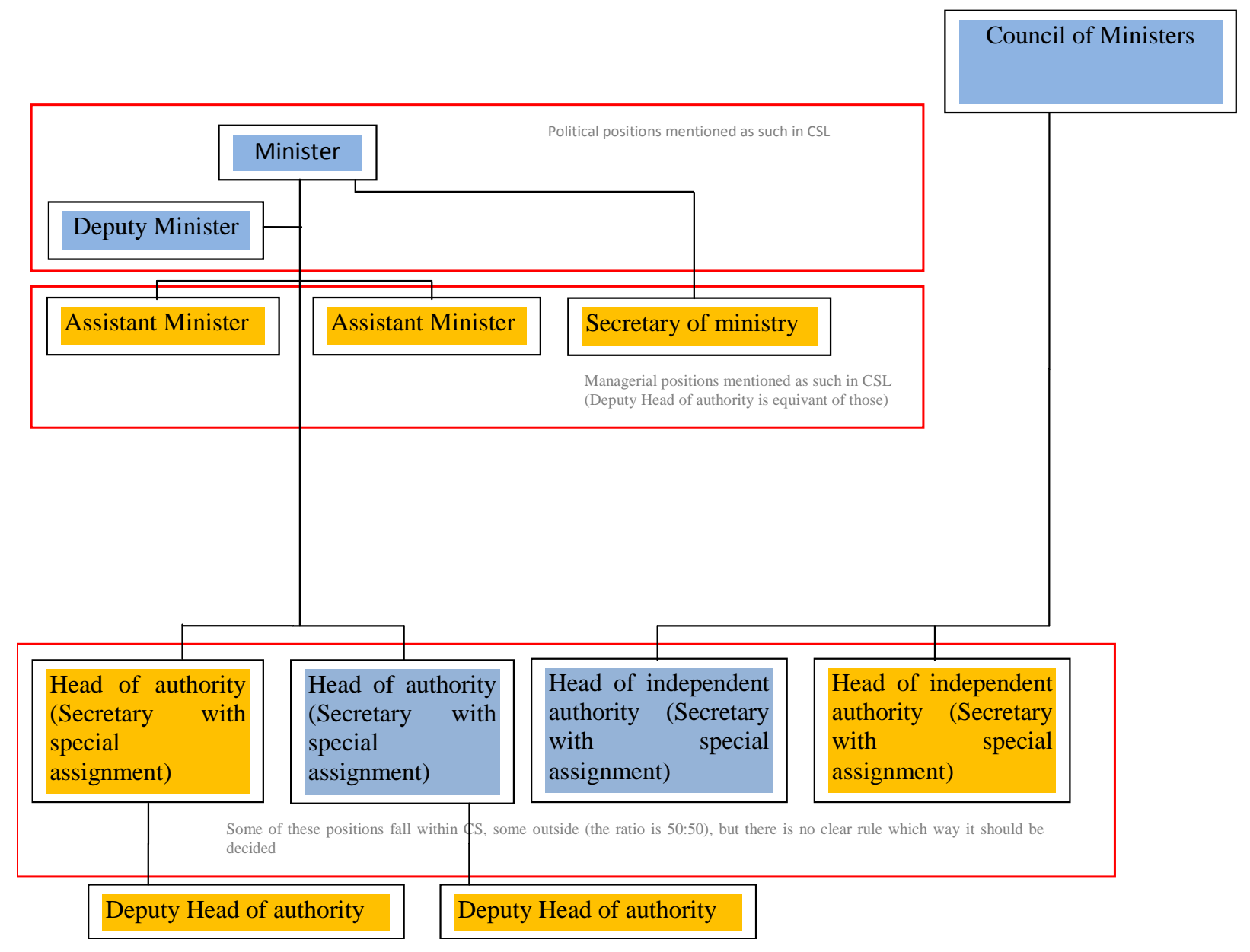




\section{Bosnia and Herzegovina, Federation}

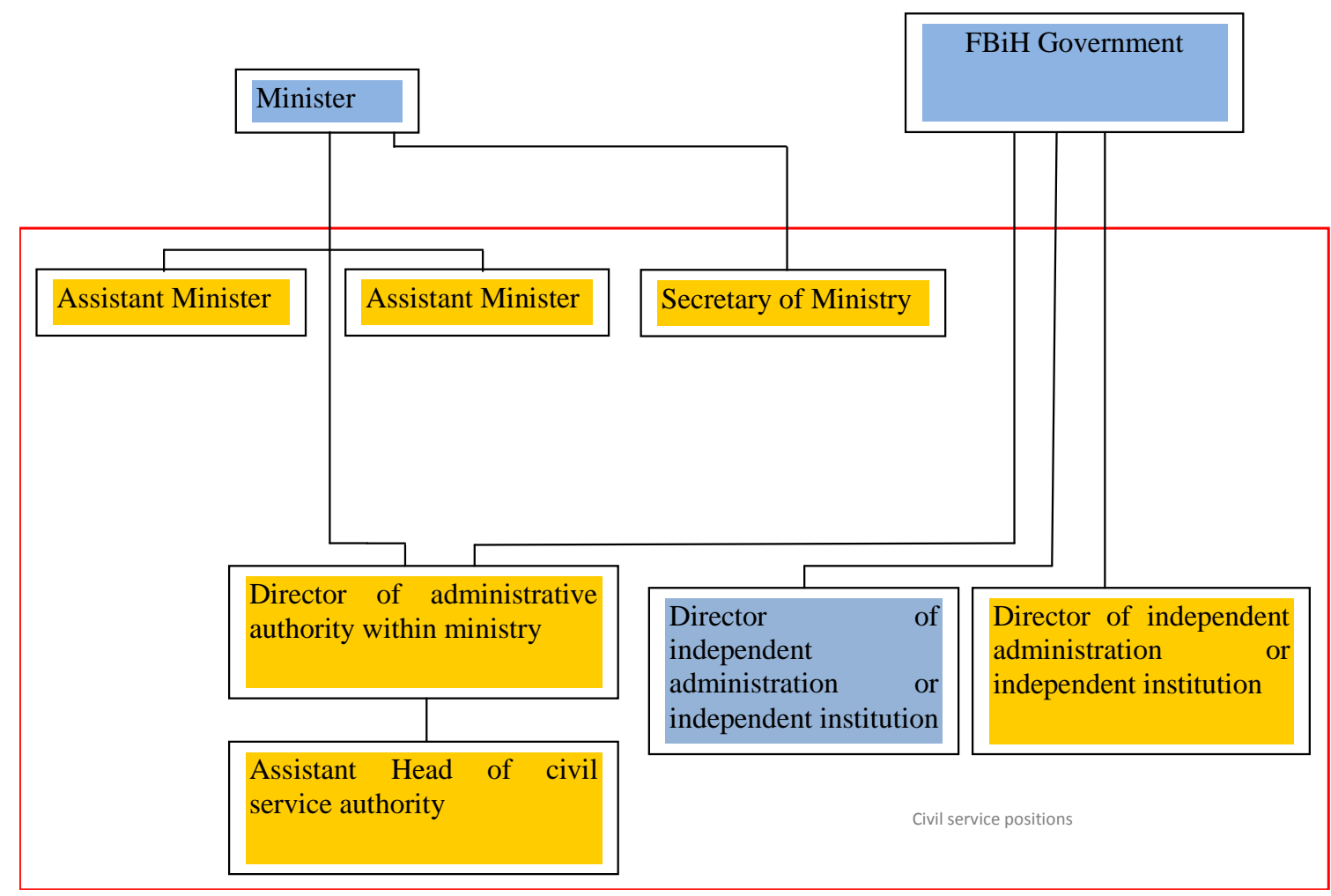




\section{Bosnia and Herzegovina, Republika Srpska}

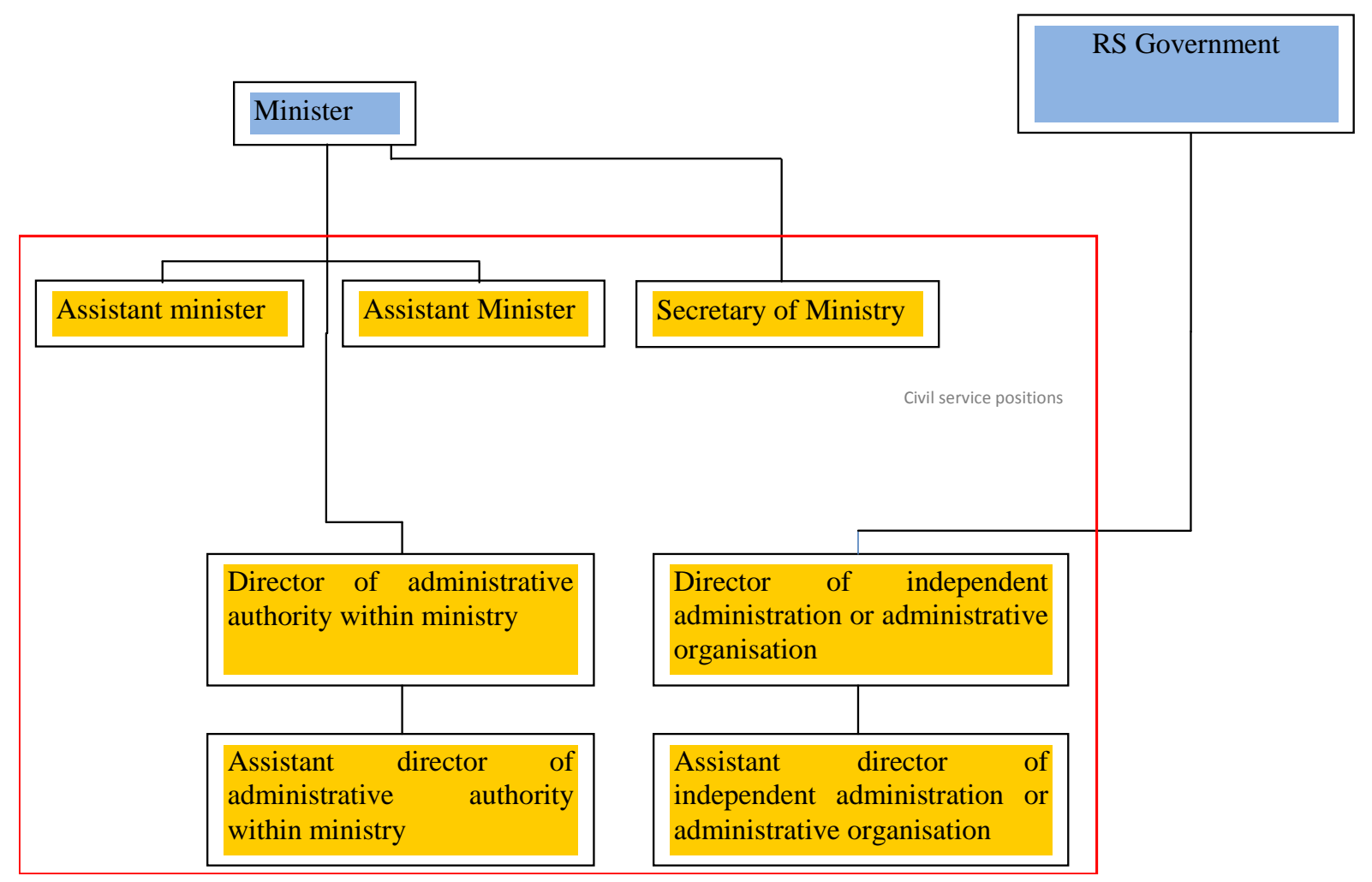




\section{Kosovo}
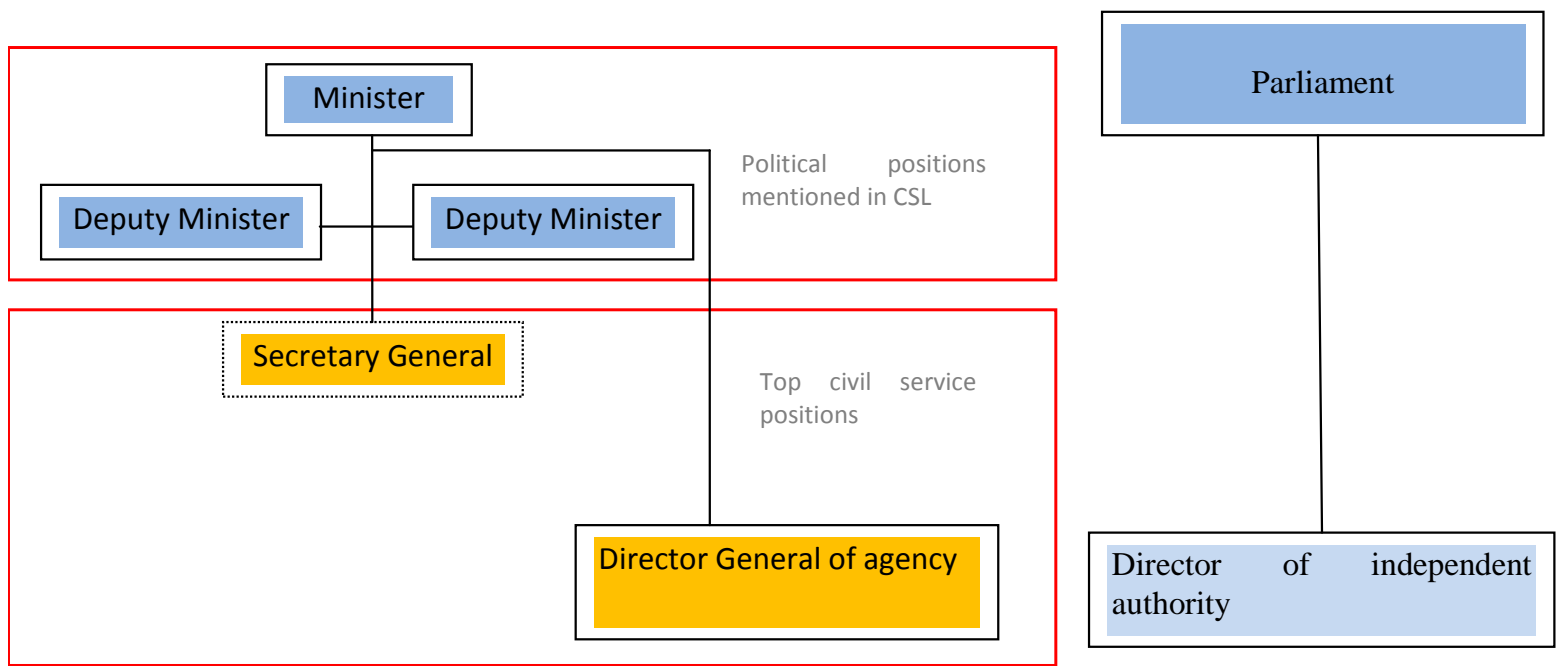

The former Yugoslav Republic of Macedonia

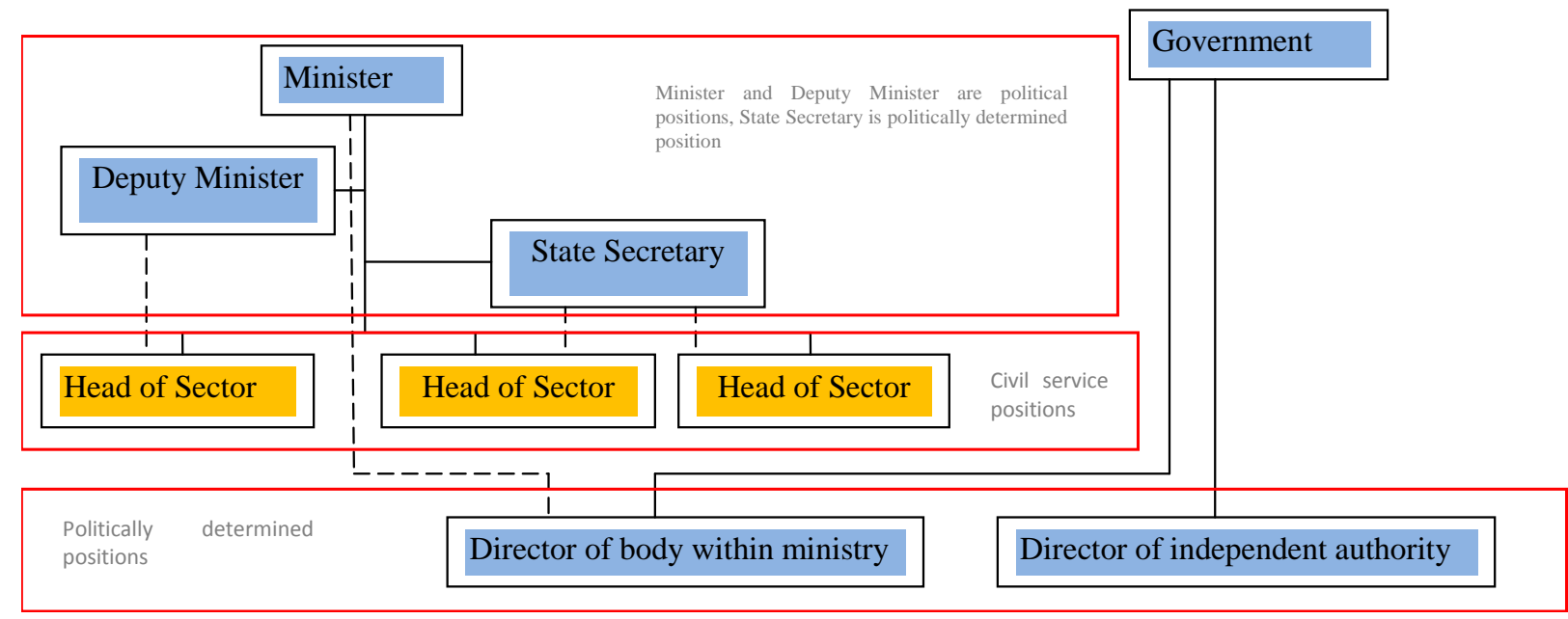




\section{Montenegro ${ }^{111}$}

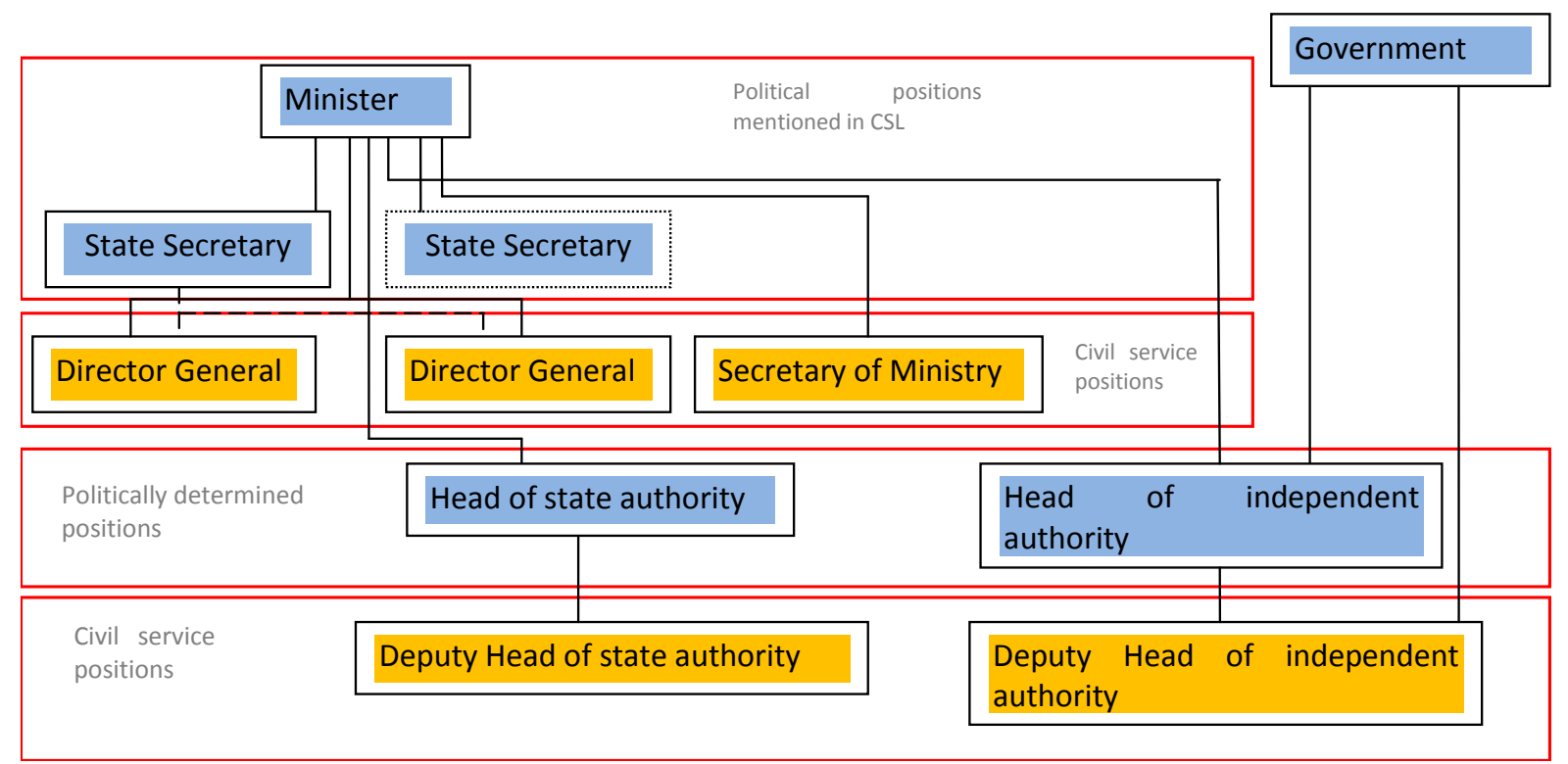

\section{Serbia}
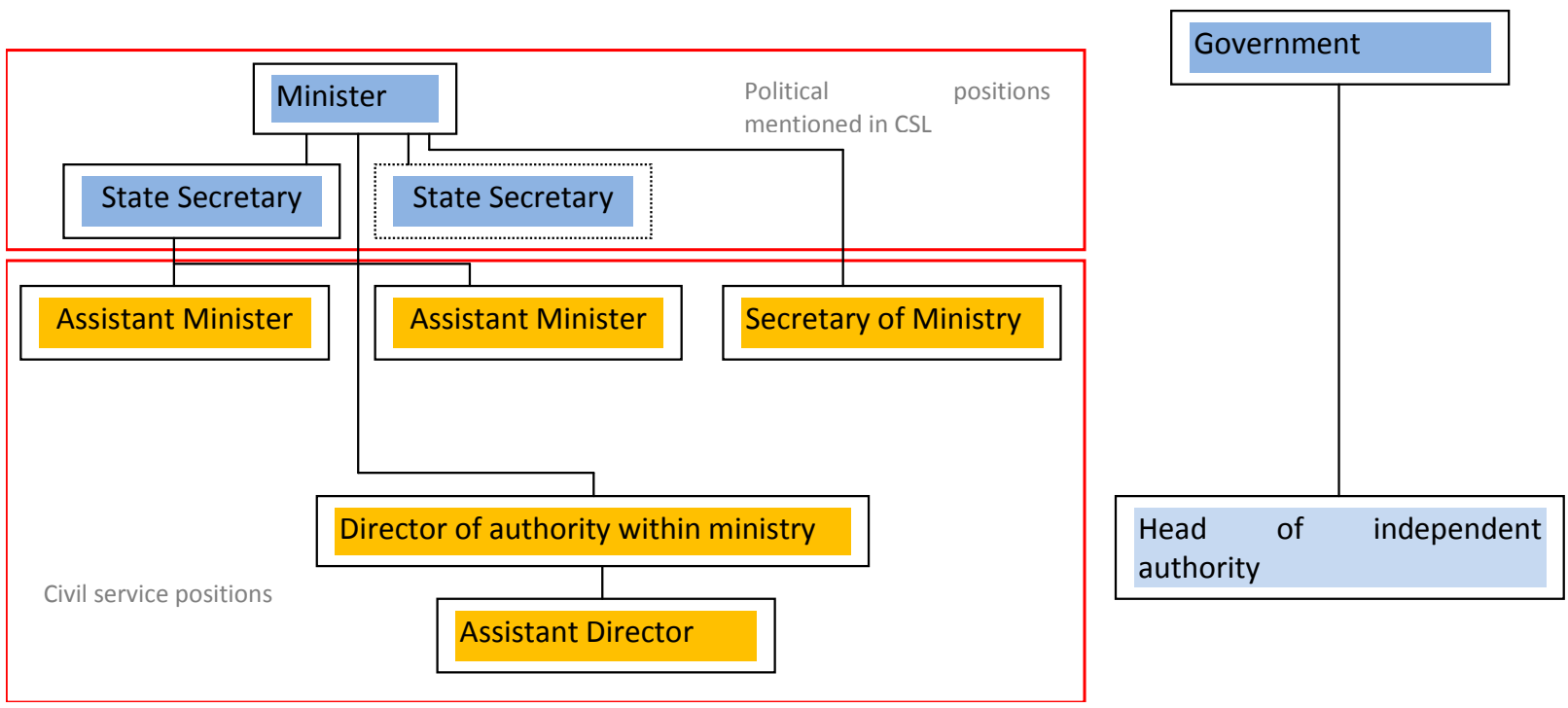

111 According to the recently adopted Civil Service Law, the heads of administration authorities were included in the scope of the CS Law. The notion of heads of administration authorities encompasses both: heads of state authorities and heads of independent authorities, as shown in the chart above. 


\title{
Annex 3. Description of recruitment processes in the Western Balkans
}

\author{
Recruitment to senior civil service positions in Albania
}

Albania has a centralised pool-recruitment system for senior civil servants (called toplevel management) that consists of three stages: recruitment to the ASPA for in-depth training; completion of the training; and appointment to a senior position. As a rule, recruitment is internal (from mid-level management positions), but exceptions are possible. Vacancies are announced centrally, and selection is organised by the NSC, which is a permanent body. The full-scale application of this system has never been carried out, however: it was foreseen in a law adopted in 2013, but since then the exceptional recruitment procedure has been used, as well as centralised pool recruitment, but without proposed mandatory training at ASPA.

\section{Application}

Clear and non-discriminatory criteria are included in the legislation, as is the merit principle, and the deadline to submit applications is sufficiently long (at least 10 days after vacancy announcement). Although application for non-senior civil servant positions is possible through e-application, only paper applications are accepted for senior civil servant positions. All vacancy announcements are available on one single web page, and Albania made the process more user-friendly by accepting copies of documents, and asking for notary-certified copies in the later stages of the recruitment process only. Despite these adaptations, the number of eligible candidates remains very low $\left(2.1\right.$ per position $\left.{ }^{112}\right)$, which means recruitment is not competitive.

\section{Assessment of candidates}

The selection process is organised by the NSC, a permanent body composed of one representative of the central management unit (DoPA), two ASPA representatives, one senior civil servant representative and five independent personalities of recognised professional experience and integrity. The composition of the NSC ensures merit and non-politicisation.

Albania has taken the first step towards competency-based recruitment by describing the required competences (problem solving, managerial environment and decision making) for each level of management. However, detailed descriptions of these competences and guidelines on how to verify them in the selection process are not available. Regarding selection techniques, both written and oral testing are required, the latter in the form of a structured interview. Regulations allow for different forms of testing, such as case studies, work samples, open questions and essays, so despite the lack of a fully functioning competency framework, selection techniques are based to

${ }^{112}$ Data collected for the SIGMA 2017 assessments. 
some extent on the competencies and are generally well adjusted to the specificity of senior positions. In SIGMA's qualitative interviews, very few respondents indicated non-merit factors such as political or personal connections figuring in the assessment of candidates.

\section{Appointment}

The appointment process differs from the one applied in the other administrations of the region because of the specificity of pool recruitment. It gives ministers full discretion to choose from the pool of candidates whose competencies were verified by the NSC.

Acting positions are not allowed by legislation, and the right to appeal recruitment decisions is ensured. The effectiveness of recruitment is high, meaning that recruitment procedures filled $81 \%$ of announced vacancies in $2016^{113}$.

\section{Recruitment to senior civil service positions in Bosnia and Herzegovina}

Although the State level, FBiH and RS legislation differ, the systems that are applied have some common features. Competitions open to external and internal candidates can both be used, however at the State level and in the $\mathrm{FBiH}$, internal competition has priority, whereas in the RS, external competition is used as a rule. Selection commissions are ad hoc, composed of representatives of the civil service agencies and the bodies in which there are vacancies.

\section{Application}

The principle of merit in recruitment to senior positions is established in legislation, as are clear and non-discriminatory eligibility criteria. The deadline to submit documents is at least 10 working days from the date of announcement for the: State level, FBiH and RS (with some exceptions possible). All announcements are available on the official State-level, FBiH and RS web portals.

All these portals are user-friendly, offering the possibility to sort vacancies and subscribe to vacancy announcements.

Changing or supplementing documents after the application deadline is not possible. In the RS, only copies are required in the first phase of the application process, and in the $\mathrm{FBiH}$, no documents need to be submitted immediately. There is a slightly more formalised procedure at the State level, where authorised copies are required when candidates apply. Authorised documents can be obtained from municipal bodies, which are not costly but adds to the effort and time required. As a rule, vacancy announcements are advertised not only on the official websites but also in newspapers.

\section{Assessment of candidates}

Competitions are the only way of getting SCS positions in $\mathrm{BiH}$ and the professional and apolitical composition of selection committees is ensured, meaning that politicians cannot be members. However, in both the $\mathrm{FBiH}$ and the RS, representatives of the ministry with the vacancy are the majority, which increases the risk of political

${ }^{113}$ Data collected for the SIGMA 2017 assessments. 
interference in the selection process and limits the role of the CSA. Various selection techniques are used: at both the State level and in the $\mathrm{FBiH}$, written and oral tests are obligatory, which is not the case in the RS, where written tests are not required (apart from necessary certification). At all levels a written exam is used to filter out candidates for further testing (in the RS it is administered prior to regular selection and is a condition for candidates to take part in the competition). In some cases, the cost of pre-examination could be significant as in the RS and recognition of results between the levels is not systematic; at the State level and in the FBiH, this first selective examination is part of the selection process. The State level uses a competency framework, accompanied by a rulebook, that covers nine main competences, of which leadership, planning and organisation, human resources development, and strategic management apply at the senior management level only. The FBiH and the RS have also begun to develop a competency framework.

Ensuring equal ethnic representation in the absence of clear and detailed rules disrupts and blurs both selection and recruitment procedures.

\section{Appointments}

The appointment of acting senior civil servants is not regulated by the $\mathrm{FBiH}$ legislation, so there are no limits on using this mechanism. No data was provided to SIGMA on the actual share of acting senior civil servants, but during the data collection for SIGMA 2017 assessments, several cases were identified with the ongoing practice of appointing acting heads at all levels ${ }^{114}$.

There is also considerable leeway for discretionary appointments to senior positions in the $\mathrm{FBiH}$ and at the State level, as the list from which a candidate may be selected is unlimited. Moreover, in the $\mathrm{FBiH}$, proposed candidates are listed in alphabetical order. In the RS, the best candidate is supposed to be appointed, but there is no obligation to appoint anyone.

The right to appeal recruitment decisions is ensured.

\section{Recruitment to senior civil service positions in the former Yugoslav Republic of Macedonia}

There is neither proper recruitment nor selection for the highest civil service positions (category A), which comprise state secretaries and secretaries general (one level below the minister). These positions are SCS positions, as their rights and obligations are regulated by the CSL, but the legislation specifies a purely political process of appointment, without selection or competition. This selection process is against the merit principle. A positive factor, however, is that secretaries general are appointed from among senior civil servants. Recruitment of heads of bodies under the ministries is also not merit-based ${ }^{115}$.

\footnotetext{
${ }^{114}$ OECD (2017), SIGMA, Monitoring Report: Bosnia and Herzegovina, OECD, Paris, pp. 88-
} 89

http://www.sigmaweb.org/publications/Monitoring-Report-2017-Bosnia-and-Herzegovina.pdf

115 According to the Law on Organisation of State Administrative Bodies, the heads of administrative agencies under ministries and independent administrative bodies are not included in the scope of the civil service: their directors are freely appointed by the relevant 
Only positions two levels below the ministers (B2 positions, i.e. heads of sectors) are discussed here, as other B-category positions are either middle-management or advisory positions that do not necessarily have managerial responsibilities and fall outside the scope of this study.

The recruitment process for category B is the same as for other categories of civil servants, thus does not fully account for the specificity of higher managerial positions. Recruitment is partially centralised, in that the Agency for Administration is responsible for announcing vacancies and organising the recruitment process. Recruitment is open to external candidates.

\section{Application}

Non-discriminatory requirements are defined in legislation, which also privileges persons with special needs. The principle of merit is also included in the legislation.

Vacancy announcements are posted on one government web page and it is also obligatory to advertise them in at least three daily newspapers. Candidates are permitted to present copies of documents, and they are verified only after the first part of the selection procedure, the written test. This solution is user-friendly, but the list of requirements set by law seems excessive, as candidates are supposed to provide recognised language and information technology (IT) certificates, which can be costly and time-consuming.

\section{Assessment and selection}

The selection process is regulated in detail in primary legislation, which is not a good practice because procedural aspects should be regulated by secondary legislation. The selection of candidates is anonymous, following formal checking of applications: a knowledge test; psychometric tests; an authenticity check of documents; an interview; and a personality test. As the same selection techniques are used for category B civil servants as for non-managerial civil servants, they cannot be well aligned to the needs of two different groups of positions. To increase transparency and limit opportunities for cheating, two unusual solutions are used: recording and live streaming of testing, and blocking the radio frequency range in the examination rooms to make outside communications impossible for candidates. Interviews are also part of the procedure. Recruitment committees are established on an ad hoc basis by the Agency for Administration and consist of a representative of the Agency, two representatives of the body in which the vacancy is announced (the human resources unit and unit with vacancy), and a member of the Secretariat for Implementation of the Ohrid Framework Agreement (ensuring equitable representation in the administration). This composition does not fully deflect political pressure, however, as $50 \%$ of the committee represents the body that has the vacancy.

political authority. There are no logical grounds for this practice, as the functions of most of these positions are clearly more managerial and less political than, for instance, those of the secretaries of ministries (Law on Organisation of State Administrative Bodies, Articles 12 and 47, paragraph 2). 


\section{Appointment}

The appointment process takes equal ethnic representation into account by privileging candidates from underrepresented communities. Apart from this, the principle of appointing the highest-ranked candidate is applied. The right to appeal recruitment decisions is ensured.

\section{Recruitment to senior civil service positions in Kosovo}

In Kosovo, the recruitment of senior civil servants (one level below minister) is centrally organised. Each selection process is managed by an ad hoc Criteria Assessment Commission, appointed by the Minister of Public Administration. For other senior positions (two levels below minister), selection is organised in a decentralised way by each institution separately. Standard job descriptions are set by the Ministry of Public Administration and can be adjusted at the request of the body. In principle, appointments to senior positions should be made from existing civil servants, but if there are no candidates, an open competition may be organised. The description below relates to centralised recruitments of senior civil servants one level below the minister.

\section{Application}

The merit principle and clear, non-discriminatory eligibility criteria are ensured by legislation. Deadlines for submitting applications are not regulated in the legislation, so they can be too short. Only paper applications are accepted and all documents need to be notary-approved, which is overly burdensome, but candidates may supplement/correct their application files if something is missing. The government web page is the only way in which a vacancy can be advertised, and it is not userfriendly, as it does not allow for sorting and subscribing to vacancy announcements.

\section{Assessment and selection}

Competitions are the only way of getting a senior civil service position. The Criteria Assessment Commission (CAS), established by the Ministry of Public Administration, consists of five members: three secretaries general and two external experts (one academic and the other from an NGO). Two members are appointed by the institution with the vacancy. As the CAS is appointed on an ad hoc basis, it is more difficult to ensure its professionalism.

The contents and the methods for assessing and selecting candidates to SCS positions are not regulated beyond the pre-screening of applicants, which leaves too much discretion in the hands of the Commission and does not guarantee merit-based selection. Only an oral examination is required, and a competency framework has not been established.

\section{Appointments}

Appointments are made from among the highest-ranked candidates (up to three), but justification for the final selection is not required. Legislation does not allow acting positions to continue for longer than three months, but in practice acting senior civil servants amounted to $8 \%$ of all senior civil servants at the end of 2016. Some preference for hiring from minority groups is ensured by civil service legislation.

The right to appeal recruitment decisions is ensured. 


\section{Recruitment to senior civil service positions in Montenegro}

In Montenegro, provisions for SCS recruitment differ from those for other civil servants. The recruitment procedure is quite centralised, with the HRMA responsible for appointing recruitment committees and announcing competitions. As recruitment committees are created on an ad hoc basis and one out of the three members is a representative of the HRMA, the HRMA therefore does not control the final result. Unlike in most other countries in the Western Balkans, SCS positions can be filled via open competitions only.

\section{Application}

The application process is formally well regulated. The merit principle is included in legislation, the eligibility criteria are not discriminatory, and the deadline to apply is long enough to enable candidates to complete all files (15 days). Moreover, all announcements are placed on one governmental portal and vacancies are announced not only on the government web page but also in newspapers. Candidates are allowed to submit copies of documents, and required to present original documents at the request of the HRMA only. The web page with vacancy announcements is not userfriendly, however, as it does not allow interested individuals to subscribe to announcements and it only allows the sorting of vacancies to a limited extent. Applications may be partially submitted online, but the number of eligible candidates per position is extremely low ( 1.4 in $2016^{116}$ ); it has been below two since 2014 , which is even more alarming as all competitions are open to external candidates.

\section{Assessment and selection}

Selection for senior managerial positions in Montenegro is conducted by committees formed by the HRMA. Committees consist of a representative of the appointing authority, an external expert (selected by the HRMA) and an HRMA representative ${ }^{117}$. There are no guarantees in legislation, however, that politicians cannot be members of selection committees. Furthermore, the selection process itself is not designed in a professional way: first, as entry requirements are very general and competency profiles are non-existent, there are not enough benchmarks against which the committee may assess candidates. Second, selection is based on structured interviews only - written testing is not required - but there are no guidelines on how to properly conduct a structured interview ${ }^{118}$. This limits the transparency of the entire process. A preliminary list of competencies has been drafted, but has not yet been described in detail nor introduced into legislation.

\section{Appointment}

Current legislation allows for a candidate to be appointed from the five highest-ranked applicants (justification is obligatory if the highest-ranked candidate is not appointed).

\footnotetext{
${ }^{116}$ Data collected for the SIGMA 2017 assessments.

117 According to the recently adopted CSL, the heads of administration authorities were included in the CSL and covered by merit-based competitive recruitment procedures. However, in relation to those positions, the composition of selection committees is slightly different.

${ }^{118}$ According to the recently adopted CSL, written testing will be mandatory.
} 
This clearly leaves too much room for subjective decisions, especially considering the small number of eligible applicants ${ }^{119}$.

Legislation limits how long acting senior civil servants may be employed, but also allows non-civil servants to be appointed as acting senior civil servants, which is a loophole that creates the risk that unqualified or political candidates will be brought in.

The right to appeal recruitment decisions is ensured.

\section{Recruitment to senior civil service positions in Serbia}

Serbia employs a centralised model for selecting senior civil servants, whereby selection is performed by ad hoc selection committees appointed by the High Civil Service Council. Internal competitions open to existing civil servants are carried out first, but if they do not result in appointment, open competitions may be organised. Selection procedures for all levels of SCS positions are the same, regardless of whether they are open or internal competitions. Vacancy announcements are managed by the HRMS, which ensures a coherent approach to defining requirements.

\section{Application}

The principle of merit is included in recruitment legislation, and clear, nondiscriminatory eligibility criteria are defined. Internal competitions are open only to civil servants already occupying appointed senior positions, or who in the two years previous received the highest performance appraisal grade.

In open competitions, the time frame to file an application is eight days minimum, which is too short as it does not allow candidates sufficient time to collect documents and apply.

Vacancies are advertised quite broadly, not only on the HRMS web page but on the e-government portal, bulletin boards and through the National Employment Service.

The HRMS website is user-friendly and allows users to sort and subscribe to vacancy announcements. The average number of eligible candidates is 5.2 per position ${ }^{120}$, which is high compared with other Western Balkan administrations.

The application process could be made more citizen-friendly, however; for example, by allowing candidates to present copies of documents in the first phase, and originals or notary-authorised copies later in the process. Electronic application is not available, although Serbia is currently developing new functionalities of the system to allow for automatic data exchange among state registers to limit the number of documents required of applicants.

\section{Assessment and selection}

Legislation ensures that selection committees are professional, their composition and functions are well defined, and they are free of political influence. They consist of

\footnotetext{
119 The recently adopted CSL limits the room for subjectivity to the three highest-ranked candidates, which given the small number of candidates in Montenegro, still may result in the situation where any of the eligible candidates could get the position.

${ }^{120}$ Data collected for the SIGMA 2017 assessments.
} 
selected members of the High Civil Service Council (experts or senior civil servants) and experts in certain fields, and only one member may come from the body for which the competition is organised. This composition ensures that the selection process is not subject to pressure from the ministry in which the vacancy exists.

A comprehensive competency framework has been designed, but has not yet been enforced. This renders the selection process more complicated, and less adequate for recruiting senior staff. Moreover, legislation does not specify which forms of candidate testing should be applied. Secondary legislation does not make written tests obligatory, which is a significant shortcoming, and oral testing is to be conducted in the form of a structured interview. Although the legislation lists a variety of possible means of testing candidates, such as tests, essays and case studies, none of them is obligatory. Standardised tests are also used.

\section{Appointment}

The most problematic stage of competitions in Serbia is the appointment phase. First, employers are presented with a list of up to the three highest-ranked candidates, but they are under no obligation to appoint any of them. This solution seems reasonable, but is apparently misused in practice, as only 11 candidates were appointed to senior positions in 2016, out of 55 selection processes in which candidates were proposed by selection committees. This casts doubt on the credibility of the selection process and its cost-efficiency, and may also indicate that, although selection procedures are functional, there is no motivation in the political sphere to respect merit-based appointments.

Another, even more serious, problem is the appointment of most senior civil servants as acting positions. In 2016, as many as $60 \%$ of all senior positions were occupied by acting civil servants, the number of which had increased from 2015; only $26 \%$ of all positions were filled through competitive procedures as prescribed by law in 2016. These acting civil servants were appointed without taking part in any kind of meritbased competition, or they had occupied SCS positions before and, instead of having their terms prolonged, they were simply employed as acting senior civil servants. What is more, acting senior civil servants may also be recruited from outside the civil service. Although legislation sets the limit for acting positions at six months (with a three-month extension possible), apparently this regulation is not respected. Thus, the formal selection procedure appears advanced but has very little practical value. The right to appeal recruitment decisions is ensured. 


\section{The SIGMA Programme}

SIGMA (Support for Improvement in Governance and Management) is a joint initiative of the OECD and the European Union (EU), principally financed by the EU. SIGMA has been working with partner countries on strengthening public governance systems and public administration capacities for 25 years.

In partnership with the European Commission (EC) Directorate-General for Neighbourhood and Enlargement Negotiations (DG NEAR), we currently work with:

Albania, Bosnia and Herzegovina, the former Yugoslav Republic of Macedonia, Kosovo, Montenegro, Serbia, and Turkey as EU candidate countries and potential candidates; and

Algeria, Armenia, Azerbaijan, Egypt, Georgia, Jordan, Lebanon, Moldova, Morocco, Tunisia and Ukraine as EU Neighbourhood countries.

SIGMA provides assistance in six key areas:

1. Strategic framework of public administration reform

2. Policy development and co-ordination

3. Public service and human resource management

4. Accountability

5. Service delivery

6. Public financial management, public procurement and external audit.

SIGMA reviews and gives feedback on:

- Governance systems and institutions

- Legal frameworks

- Reform strategies and action plans

- Progress in reform implementation.

SIGMA provides:

- Advice on the design and prioritisation of reforms

- Methodologies and tools to support implementation

- Recommendations for improving laws and administrative arrangements

- Opportunities to share good practice from a wide range of countries, including regional events

- Policy papers and multi-country comparative studies.

For further information on SIGMA, consult our website: www.sigmaweb.org

\section{(C) OECD 2018}

As SIGMA is part of the Organisation for Economic Co-operation and Development (OECD), the same conditions of use apply to its publications: http://www.oecd.org/termsandconditions. 